\title{
Aspectos da resistência do aluno de medicina na busca por auxílio psicológico
}

Tese apresentada à Faculdade de Medicina da Universidade de São Paulo para obtenção do título de Doutor em Ciências

Programa de Patologia

Orientador: Prof. Dr. Raymundo Soares de Azevedo Neto

(Versão corrigida. Resolução CoPGr 6018, de 13 de outubro de 2011 A versão original está na disponível na Biblioteca FMUSP) 


\section{Dados Internacionais de Catalogação na Publicação (CIP)}

Preparada pela Biblioteca da

Faculdade de Medicina da Universidade de São Paulo

Creprodução autorizada pelo autor

Taborda, Anna Lucia de Camargo Gargiulo

Aspectos da resistência do aluno de medicina na busca por auxílio psicológico / Anna

Lucia de Camargo Gargiulo Taborda. -- São Paulo, 2015.

Tese(doutorado)--Faculdade de Medicina da Universidade de São Paulo. Programa de Patologia.

Orientador: Raymundo Soares de Azevedo Neto.

Descritores: 1.Estudantes de medicina 2.Psicoterapia 3.Depressão 4.Ansiedade 5.Transtornos mentais 6.Mecanismos de defesa 7.Contratransferência/psicologia 8.Ego 9.Superego 10.Personalidade 11.Apoio social

USP/FM/DBD-311/15 
A meu marido José Renato; e a meus filhos Mariana, Gabriela e Pedro. 


\section{Agradecimentos}

A Luiz Roberto Millan, exemplo de ética e dedicação na compreensão das questões que envolvem o universo do estudante de Medicina, sobre o qual produziu importantes conhecimentos, frutos de sua sensibilidade e anos de experiência; por ter plantado a ideia desse estudo, contribuindo com seu conhecimento e sugestões, e, especialmente, despertando em mim a curiosidade e o apreço por esse universo estudantil; e pela generosidade com que contribuiu ao meu desenvolvimento e à minha formação como profissional.

À Profa. Marília Millan, psicóloga de extrema sensibilidade, por seu talento na arte de ensinar a Psicanálise, e desenvolver a capacidade na observação e difícil tarefa de compreender o funcionamento psíquico daqueles que nos procuram; e por acreditar na possibilidade de realização dessa pesquisa.

A Raymundo Soares de Azevedo Neto, que, com sua sabedoria ímpar, generosidade e experiência, orientou-me em todos os momentos desse trabalho, extrapolando essa função por meio da realização de todos os testes estatísticos, da disponibilidade em atender a todas as dúvidas e questões que surgiram, das contribuições fornecidas e do apoio e incentivo necessários para a realização dessa pesquisa.

Ao psiquiatra e estudioso da saúde mental dos médicos Luiz Antonio NogueiraMartins, por todas as referências bibliográficas sugeridas que muito contribuíram para a compreensão desse tema e realização desse estudo.

Ao meu marido Jose Renato e flhos Mariana, Gabriela e Pedro pelo apoio e incentivo que me deram ao longo da realização desse trabalho.

A todos os alunos que participaram dessa pesquisa, revelando um pouco de suas angústias e contribuindo para essa pesquisa. 


\section{NORMALIZAÇÃo ADOTADA}

Esta tese está de acordo com as seguintes normas, em vigor no momento desta publicação:

Referências: adaptado de International Committee of Medical Journals Editors (Vancouver). Universidade de São Paulo. Faculdade de Medicina. Divisão de Biblioteca e Documentação. Guia de apresentação de dissertações, teses e monografias. Elaborado por Anneliese Carneiro da Cunha, Maria Julia de A. L. Freddi, Maria F. Crestana, Marinalva de Souza Aragão, Suely Campos Cardoso, Valéria Vilhena. 3a ed. São Paulo: Divisão de Biblioteca e Documentação; 2011.

Abreviaturas dos títulos dos periódicos de acordo com List of Journals Indexed in Index Medicus. 


\section{SUMÁRIO}

\section{LISTA DE SIGLAS E ABREVIATURAS \\ LISTA DE TABELAS \\ RESUMO}

ABSTRACT

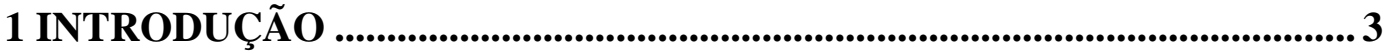

$1.1 \mathrm{O}$ adolescente universitário ........................................................................... 4

1.2 A saúde mental do estudante de Medicina .....................................................6 6

1.2.1 A psicopatologia do estudante de Medicina ............................................. 7

1.3 Consequências da falta de tratamentos dos estudantes universitários........ 7

1.4 Acesso a tratamentos especializados .........................................................9

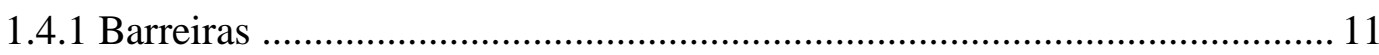

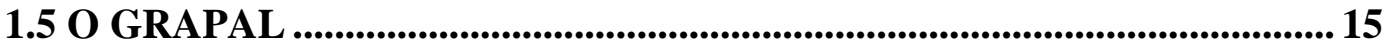

$1.6 \mathrm{O}$ funcionamento psíquico e a resistência - breve exposiçãa....................... 16

2 OBJETIVOS ........................................................................................................................ 25

2.1 Objetivos principais.......................................................................................... 25

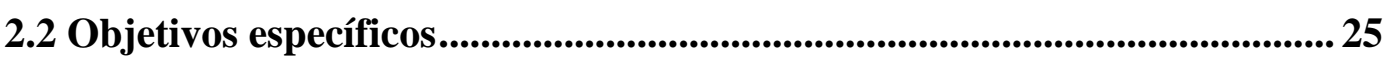

3 CASUÍSTICA E MÉTODOS .......................................................................... 29

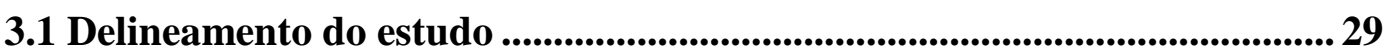

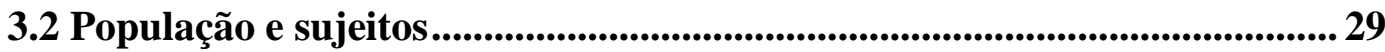

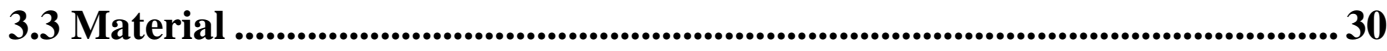

3.3.1 Inventário de Depressão de Beck (BDI) …….............................................. 30

3.3.2 Inventário de Ansiedade de Beck ............................................................. 30

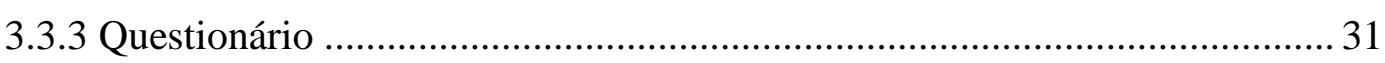

3.3.4 Teste de Apercepção Temática................................................................. 32

3.3.5 O embasamento teórico adotado na interpretação do TAT .......................... 34

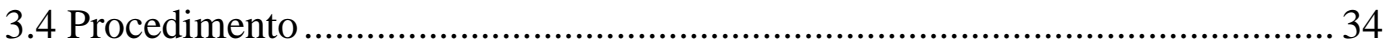

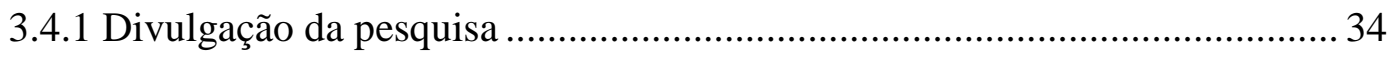

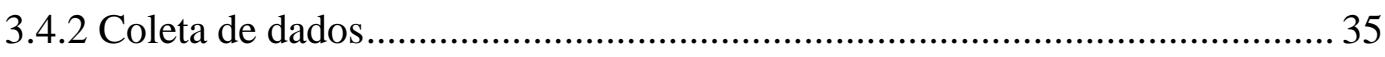

3.4.2.1 Inventários de Depressão e de Ansiedade de Beck e questionário

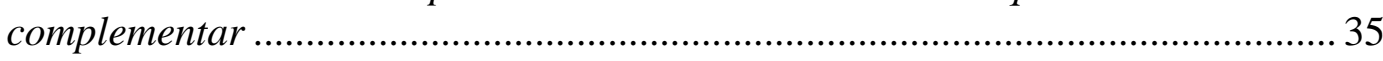

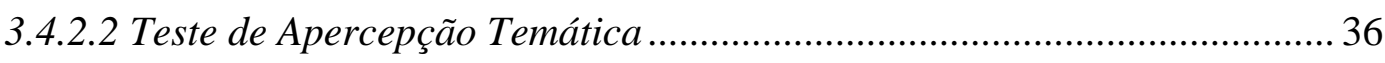

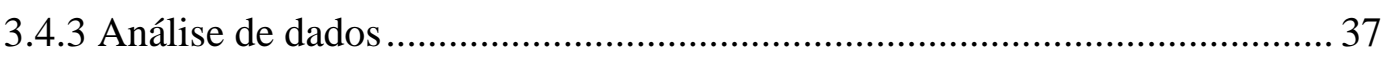




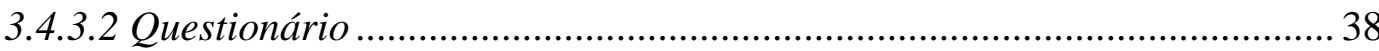

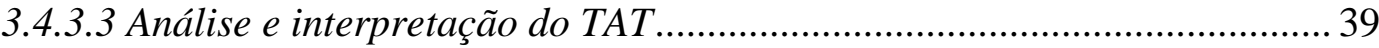

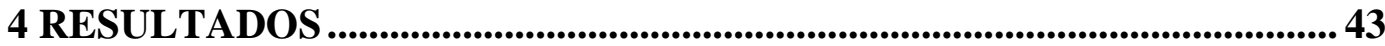

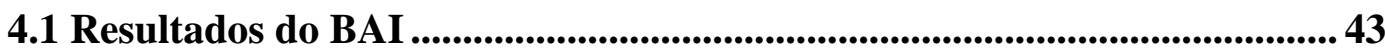

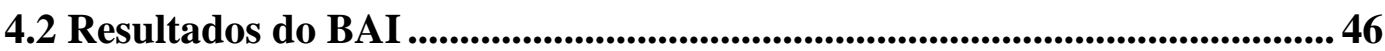

4.3 Resultados do questionário ...................................................................................49

4.3.1 Associação dos Ciclos e anos da graduação à demanda por auxílio psicológico.

4.3.2 Associação dos gêneros à demanda por auxílio psicológico

4.3.3 Associação da intensidade dos sintomas ansiosos e depressivos à demanda por auxílio psicológico

4.3.4 Associação entre a demanda por auxílio psicológico, o gênero, a intensidade de sintomas e o acesso aos serviços em saúde mental..........................................53

4.3.5 Associação entre os sujeitos que receberam indicação de terceiros para receber auxílio psicológico, o gênero e a intensidade dos sintomas ..................... 56

4.4 Justificativas dadas às perguntas do questionário ........................................ 57

4.4.1 Razões para não procurar auxílio psicológico ou não dar sequência ao tratamento (formas de resistência) ......................................................................5 57

4.5 Resultados dos TATs.......................................................................................60

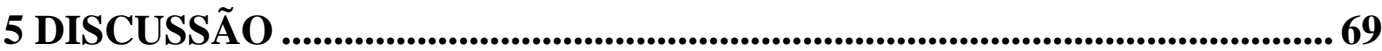

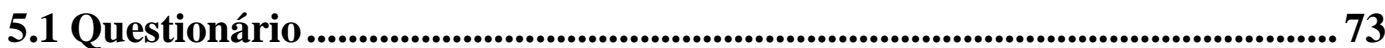

5.2 Acesso aos serviços de saúde mental ...................................................... 81

5.3 Justificativas apresentadas ao comportamento de não buscar auxílio

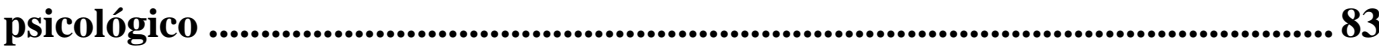

5.4 Teste de Apercepção Temática ........................................................................... 88

5.4.1 Embasamento teórico adotado na análise do TAT ……............................... 88

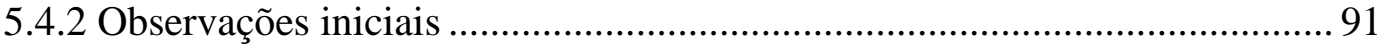

5.4.3 Análise e interpretação das pranchas ..................................................... 92

6 CONCLUSÕES..................................................................................................... 109

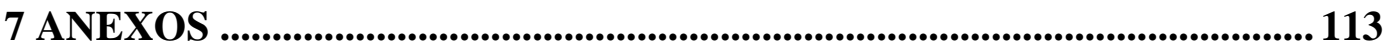

7.1 ANEXO A - Questionário ....................................................................... 113

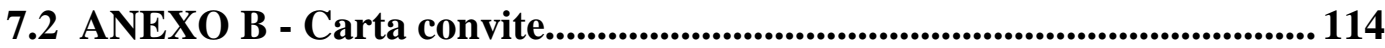

7.3 ANEXO C - Aprovação pelo Comitê de Ética ........................................... 115

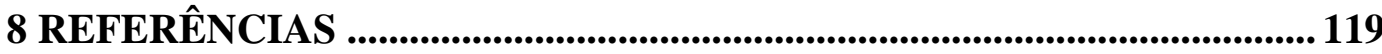




\section{Lista de Siglas Abreviaturas}

BAI Inventário de Ansiedade de Beck

BDI Inventário de Depressão de Beck

CAOC Centro Acadêmico Oswaldo Cruz

EUA Estados Unidos da América

FMUSP Faculdade de Medicina da Universidade de São Paulo

GRAPAL Grupo de Assistência Psicológica ao Aluno

HC Hospital das Clínicas

OSCE Objective Structured Clinical Examination

TAT Teste de Apercepção Temática

TCLE Termo de Consentimento Livre e Esclarecido 


\section{LiSTA DE TABELAS}

Tabela 1 Frequência de sujeitos que responderam o BAI em relação ao gênero e o Ciclo da graduação.

Tabela 2 Frequência de sujeitos por níveis de sintomas ansiosos segundo os Ciclos da graduação

Tabela 3 Teste de Kruskal-Wallis para BAI em relação aos Ciclos da graduação

Tabela 4 Intensidade dos sintomas ansiosos em relação aos anos da graduação 45

Tabela 5 Intensidade dos sintomas ansiosos em relação ao gênero 45

Tabela 6 Frequência de sujeitos que responderam o BDI em relação aos Ciclos da graduação 46

Tabela 7 Nível de sintomas de depressão segundo o Ciclo da graduação.... 46

Tabela 8 Teste de Kruskal-Wallis para BDI em relação aos Ciclos da graduação

Tabela 9 Intensidade dos sintomas depressivos em relação aos anos da graduação

Tabela 10 Intensidade de sintomas depressivos em relação ao gênero 48

Tabela 11 Associação da frequência de alunos com demanda para atendimento psicológico (inclusive psiquiátrico) e os Ciclos da graduação ...... 49

Tabela 12 Associação da frequência de alunos com demanda para auxílio psicológico e os anos da graduação 50

Tabela 13 Associação do gênero à demanda por auxílio psicológico 50

Tabela 14 Nível de sintomas de ansiedade em relação à demanda por auxílio psicológico

Tabela 15 Teste de Kruskal-Wallis para escores de ansiedade e demanda por auxílio psicológico 52

Tabela 16 Níveis de sintomas depressivos em relação à demanda por auxílio psicológico 
Tabela 17 Teste de Kruskal-Wallis para escores de depressão e demanda por auxílio psicológico

Tabela 18 Intensidade dos sintomas ansiosos dos sujeitos em processo psicoterapêutico em relação ao gênero 53

Tabela 19 Intensidade dos sintomas depressivos dos sujeitos em processo psicoterapêutico segundo o gênero 54

Tabela 20 Nível de sintomas ansiosos e depressivos dos sujeitos com demanda por auxílio psicológico em relação ao tratamento psicológico em andamento 55

Tabela 21 Associação do gênero com o recebimento de indicação de terceiros para buscar auxílio psicológico. 56

Tabela 22 Frequência de sujeitos que receberam indicação de terceiros para buscar auxílio psicológico e o nível de sintomas ansiosos

Tabela 23 Frequência de sujeitos que receberam indicação de terceiros para buscar auxílio psicológico e o nível de sintomas depressivos ........57

Tabela 24 Sujeitos convidados para participar do TAT ….............................. 61

Tabela 25 Escores, gênero e ano da graduação dos sujeitos que realizaram o TAT 62

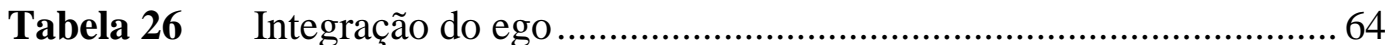

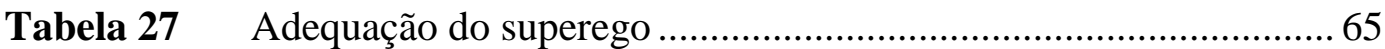




\section{RESUMO}

Taborda ALCG. Aspectos da resistência do aluno de medicina na busca por auxílio psicológico [Tese]. São Paulo: Faculdade de Medicina, Universidade de São Paulo; 2015.

Objetivo: Estimar a prevalência de depressão e ansiedade entre os alunos do primeiro ao sexto ano do curso de medicina da FMUSP e como manifestam a resistência na busca por auxílio psicológico. Método: aplicação dos Inventários de Depressão (BDI) e Ansiedade de Beck (BAI) e Questionário aos alunos matriculados no ano de 2012 na Faculdade de Medicina da USP, bem como do Teste de Apercepção Temática àqueles que preencheram os critérios de resistência à busca de auxílio psicológico. Resultados: Dos 1.034 alunos matriculados na graduação em 2.012, $439(42,46 \%)$ responderam adequadamente o BAI e BDI, sendo que desses, $13,4 \%$ sujeitos apresentaram sintomas de ansiedade em nível Leve e 5,5\% em nível Moderado. Dentre os 437 Inventários de Depressão respondidos, 16,0\% indicaram nível Leve e 4,1\% Nível Moderado de depressão. Não houve diferença significativa entre os gêneros em relação aos níveis de depressão e ansiedade encontrados. Dos 82 sujeitos que apresentaram ansiedade em nível Leve e Moderado, 56 (68,3\%) afirmaram ter demanda por algum tipo de serviço em saúde mental, mas apenas 12 $(14,5 \%)$ estavam em tratamento. Dos 87 sujeitos que apresentavam sintomas depressivos em nível Leve e Moderado, $58(66,7 \%)$ apresentaram demanda para tratamento psicológico e somente $17(19,6 \%)$ estavam em terapia. Foram enviadas 109 Cartasconvites aos sujeitos que revelaram interesse em buscar auxílio psicológico e não buscaram e aos que apresentaram sintomas depressivos e ansiosos em nível moderado para participarem do Teste de Apercepção Temática, mas compareceram a essa atividade apenas 7 sujeitos, todos com sintomas de ansiedade e depressão em níveis mínimo e leve. Foram aplicadas 5 pranchas do TAT a esses sujeitos que, de forma geral, revelaram sentimentos que em sua maioria eram negativos ou pessimistas. As ansiedades prevalentes foram as paranoides e as relacionadas ao desempenho de tarefas, as defesas mais percebidas foram a maníaca e a racionalização, a integração do ego variou entre fraca, razoável e boa e a adequação do superego apontou para um superego exigente e rígido. Conclusão: A maioria dos alunos de medicina com ansiedade e depressão em níveis Leve e Moderado apresentou resistência para buscar auxílio psicológico. A resistência se manifestou em dois níveis: um mais intenso, que impede o sujeito de perceber sua doença, seus sintomas e seu próprio sofrimento psíquico; e em um nível menos intenso, em que o sujeito percebe sua doença e/ou sintomas e reconhece a necessidade de buscar auxílio, mas não o procura. A resistência parece estar relacionada a um modo de "ser" idealizado, associado a um superego rígido e exigente e compartilhado e perseguido pelo corpo discente.

Palavras chave: Estudante de medicina; Depressão; Ansiedade; Resistência; Auxílio psicológico; Teste de Apercepção Temática; Inventário Beck de Depressão e Ansiedade; Defesas psíquicas; Ideal de ego; Superego. 


\begin{abstract}
Taborda ALCG. Aspects of Medical student resistance to seeking psychological assistance [Thesis]. São Paulo: "Faculdade de Medicina, Universidade de São Paulo"; 2015.
\end{abstract}

Objective: To estimate the prevalence of depression and anxiety among first-to-sixth year medical students of FMUSP and how they resist to seek mental health support. Methodology: This study used cross-setional survey data from a representative sample of undergraduated medical students $(\mathrm{N}=439)$ that answered Beck Anxiety Inventory (BAI) and Beck Depression Inventory (BDI) and a Supplemental Questionnaire. The students that scored positively for depression and anxiety and those who demand for psychological treatment but had not accessed any mental health service were invited to the Thematic Apperception Test (TAT). Results: Of the 1,034 undergraduate students attending the medical school in 2012, 439 (42.46\%) responded adequately BAI and BDI, and of them, 13.4\% students had symptoms of anxiety in Light Level and $5.5 \%$ in Moderate level. Among the 437 BDI that were considered in this survey, 16.0\% indicated Light Level and 4.1\% Moderate Level of depression. Considering gender, there was no significant difference in the levels of depression and anxiety. Of the 82 students with anxiety in Light and Moderate Level, 56 (68.3\%) reported demand for some kind of service in mental health, but only $12(14.5 \%)$ were receiving treatment. Of the 87 subjects with depressive symptoms in Light and Moderate Level, 58 (66.7\%) considered seeking for mental health care and only $17(19.6 \%)$ were in therapy. 109 students who have shown interest in seeking psychological help and have not sought and those who had depressive and anxiety symptoms in moderate level were invited to participate to the Thematic Apperception Test (TAT), but only 7 students attended this activity, all with symptoms of anxiety and depression in minimum and light levels. The TAT was used in a reduced version of 5 pictures and, in general, the students' answers revealed negative or pessimistic feelings. The paranoid anxieties were prevalent and related to performance tasks. The manic and rationalization were the most observed psychic defenses. The ego showed a variation from poor to fair good integration and the superego were pointed as demanding and rigid. Conclusion: Most medical students with anxiety and depression in Light and Moderate levels showed resistance to seek psychological help. The resistance was manifested in two levels: the more intense, which prevents the student to perceive their disease, symptoms and their own psychological distress; and a less intense level, that allows the students to perceive their illness and / or symptoms and recognizes their needs to seek help, but prevents them accessing mental health services. The resistance seems to be associated to idealized way of "being", shared by this student population.

Descriptors: Medical student; Depression; Anxiety; Resistance; Psychological; Thematic Apperception Test; Beck Depression and Anxiety; Psychic defenses; Ego ideal; Superego. 
1 INTRODUÇÃO 



\section{INTRODUÇÃO}

Inicialmente, cabe ressaltar que a busca por auxílio psicológico não é tarefa fácil para nenhum ser humano, embora seja um trabalho que, por vezes, resulta em benefícios permanentes àquele que se propõe realizá-lo.

Destaco a palavra "trabalho" para enfatizar que a atividade de buscar auxílio psicológico ou de mantê-lo, aderindo ao tratamento, impõe ao sujeito um esforço que, para alguns, é grande e penoso; para outros, nem tanto; mas sempre demanda investimentos financeiro, temporal e emocional.

São muitas as barreiras que se apresentam entre o sujeito e o atendimento psicológico. Essas, na compreensão psicanalítica, na maioria das vezes são consideradas formas através da qual se manifesta a resistência. A resistência pode, então, ser compreendida como um mecanismo de que os indivíduos se servem para defenderem-se daquilo que os fazem aproximar-se de um sofrimento que precisam evitar, fato que frequentemente ocorre durante um tratamento em saúde mental.

A profissão médica, diretamente ligada ao sofrimento humano, já foi objeto de estudo de diversas e importantes pesquisas em todo o mundo, que abordaram inúmeras características e especificidades daqueles que a exercem, e especialmente quanto ao modo como o médico se relaciona com seu próprio sofrimento.

Da mesma maneira, muito se tem estudado e pesquisado sobre os estudantes, futuros médicos. Embora os estudantes de Medicina façam parte de uma grande categoria de estudantes universitários, também apresentam certas especificidades e peculiaridades, tal qual o profissional dessa área. Mas não deixam de pertencer e compartilhar certas características desse grande grupo de universitários, constituídos, predominantemente, por jovens que vivenciam o fim da adolescência e o início da fase adulta. 


\subsection{O adolescente universitário}

Inúmeras pesquisas vêm abordando a questão da saúde mental do estudante universitário, dada a sua importância na formação dos futuros profissionais, da classe produtiva e da sociedade. Jovens profissionais bem formados e saudáveis podem contribuir de forma construtiva para uma sociedade melhor.

Ademais, poderíamos dizer que as Universidades concentram, de forma predominante, esses jovens em processo de (trans)formação, tanto em nível profissional como pessoal, que vivem a passagem do fim da adolescência para a idade adulta, especialmente no curso de Medicina que, por ser longo (6 anos de graduação mais 3, 4 ou 5 de residência, conforme a especialidade escolhida), abarca um grande período dessa fase, de forma que os alunos iniciam o curso de uma maneira e terminam de outra bem diferente.

De acordo com Aberastury e Knobel, a adolescência é um momento crucial na vida do ser humano, no qual ele vivencia um processo em que deve elaborar o luto pelas perdas infantis decorrentes das mudanças corporais que marcam esse período e das mudanças psicológicas que implicam na construção de uma nova relação do adolescente com os pais e com o mundo.

Para esses autores, a adolescência é marcada por três tipos de luto: pelo corpo infantil, pela identidade infantil e pela relação com os pais da infância, sendo que a "consequência final da adolescência seria um conhecimento de si mesmo como entidade biológica no mundo, o todo biopsicossocial de cada ser nesse momento de vida" (Aberastury, Knobel, 1989).

Nesse processo, os autores afirmam que o grupo de amigos, o grupo familiar e o grupo social têm um papel fundamental na formação da identidade do sujeito, uma vez que são as concepções que esses grupos têm dele que permitem ao adolescente formar um conceito sobre si mesmo. Assim, conforme o adolescente começa a perceber essas concepções, ele inicia a formação dos sentimentos de identidade, experimentando a aquisição de conhecimentos sobre si mesmo.

Da mesma maneira, Osório afirma que "do ponto de vista psicológico considera-se que a tarefa básica da adolescência é a aquisição da identidade pessoal. Por isso, diz-se que a crise evolutiva do processo adolescente é, sobretudo, uma crise de identidade". Esse autor, ainda, acrescenta que o sentimento de identidade é alcançado por meio do 
equilíbrio dinâmico entre três percepções: "aquilo que eu penso que sou", "o que os outros pensam que sou", e "o que eu penso que os outros pensam que sou" (Osório, 1992).

$\mathrm{O}$ autoconhecimento, "busca incessante de saber qual a identidade adulta que se vai constituir é angustiante, e as forças necessárias para superar esses microlutos e os lutos ainda maiores da vida diária obtêm-se das primeiras figuras introjetadas, que formam a base do ego e do superego desse mundo interno do ser" (Aberastury, Knobel, 1989). Assim, quanto melhor tenham sido introjetadas as figuras parentais na infância, melhor serão os processos de elaboração dos lutos.

Por isso, uma das necessidades e características da adolescência é a tendência grupal, importante nesse processo de construção da identidade. Os adolescentes se agrupam a fim de buscar um meio uniforme com o qual não se sintam estranhos ou diferentes, tendo como finalidade a conquista de sentimentos de segurança e estima pessoal. Por meio de mecanismos de identificação em massa, todos os adolescentes acabam por se identificarem com cada um do grupo (Aberastury, Knobel, 1989).

O grupo social, chamado de "grupo de iguais", funciona como um continente para os conteúdos caracterizados pela angústia relacionada à existência e à identidade do adolescente, oferecendo um ambiente propício para que ocorram trocas de experiências que permitam "a seus componentes uma melhor identificação entre os limites do eu e do outro" (Osório, 1992).

Segundo Aberastury e Knobel, algumas vezes, essa tendência grupal é forte o suficiente para impossibilitar a separação do grupo, fazendo com que o adolescente sintase pertencendo mais ao grupo com o qual se identificou do que com o grupo familiar; com isso, o adolescente transfere ao grupo parte da dependência que antes sentia em relação aos pais ou à família. Esse processo também pode ser considerado como um produto do luto realizado pela relação infantil com as figuras parentais.

Os autores acrescentam, ainda, que em "outro nível, as atuações do grupo e dos seus integrantes representam a oposição às figuras parentais e uma maneira ativa de determinar uma identidade diferente da do meio familiar" (Aberastury, Knobel, 1989).

Dessa forma, na adolescência, o "grupo constitui, assim, a transição necessária no mundo externo para alcançar a individualidade adulta" (Aberastury, Knobel, 1989), ou seja, ele acaba se constituindo como um meio de que o adolescente se serve para que, posteriormente, possa dele se afastar e assumir individualmente sua identidade adulta. 


\subsection{A saúde mental do estudante de Medicina}

É nessa época da adolescência, até a idade de 24 anos aproximadamente, que a maioria das doenças psíquicas eclode (Kessler et al., 2005). Por isso, esse é considerado um período importante para se realizar intervenções adequadas nessa população tão vulnerável ao adoecimento psíquico (Eisemberg et al., 2009).

Alguns estudos focaram na saúde mental do estudante universitário e do estudante de Medicina, e seu comportamento de busca por tratamento. Nos EUA foi realizada uma revisão de literatura sobre esse tema, comparando a prevalência de transtornos mentais entre a população universitária e seus equivalentes da população em geral, jovens adultos não universitários (Hunt et al., 2009).

Essa revisão, que abarcou dados epidemiológicos de 2008, atestou que há maior prevalência de problemas psicológicos entre estudantes universitários do que entre jovens não estudantes de idades equivalentes. E, dentre os estudantes universitários de escolas americanas e canadenses, pesquisas apontam que os dos cursos de Medicina são os mais afetados por depressão, ansiedade, burnout e problemas de saúde mental relacionados (Dyrbye et al., 2006).

Há, também, estudos que reportam que os casos de doenças mentais nas populações universitárias vêm aumentando em número e severidade (Hefner et al.; Hunt et al., 2009, Storrie et al., 2010). O Relatório Nacional dos Centros de Aconselhamentos Universitários (National Survey of College Counseling Centers) de 2013, realizado com base nas informações fornecidas por 203 Universidades dos EUA e Canadá, confirma esse aumento. Neste relatório, Diretores de 95\% desses Centros de Aconselhamento reportaram uma tendência de crescimento no número de estudantes com problemas psicológicos severos e observaram que, em relação às demandas desses alunos, nos últimos 5 anos, ocorreu um aumento dos casos que requeriam uma resposta imediata (relatado por $73 \%$ dos Diretores desses centros) e um aumento de casos com necessidade de medicação psiquiátrica (observado por $65 \%$ desses Diretores). (http://www.collegecounseling.org/wp-content/uploads/Survey-2013-4-yr-Directors1.pdf). 


\subsubsection{A psicopatologia do estudante de Medicina}

Dentre os estudantes universitários estudados, os que cursam Medicina despertam especial interesse e atenção em razão de constituírem, de acordo com algumas pesquisas, uma população mais vulnerável ao estresse, e aos distúrbios ansiosos e depressivos, adoecendo mais quando comparados à população em geral (Millan et al., 1998) e também a outros cursos (Dyrbye et al., 2006).

A preocupação com a saúde física e mental dos estudantes de Medicina parece estar presente em diversas escolas médicas de todo o mundo. Pesquisas realizadas sobre o tema apontam as condições de vulnerabilidade a que esses estudantes são expostos e o

consequente surgimento ou agravamento de doenças psíquicas, o que justifica a necessidade de tratamentos adequados a esses (Roberts et al., 2000).

Em relação às doenças mentais apresentadas pelos discentes da Faculdade de Medicina da USP, de maneira geral, o aluno apresenta "em primeiro lugar, quadros de natureza depressiva, seguidos pelo distúrbio de ansiedade", sendo que o uso de drogas é menor entre eles, quando comparados com alunos de outros cursos universitários e, raramente, apresentam quadros psicóticos (Millan et al., 1999).

Entre os estudantes de Medicina da FMUSP, os quadros psicopatológicos predominantes são os distúrbios de humor, "seguidos pelos quadros ansiosos e os distúrbios de personalidade, com destaque para a personalidade obsessiva. Os quadros psicóticos são raros e o uso de drogas, apesar de ser preocupante, é a metade do utilizado pelos outros alunos da Universidade de São Paulo, com exceção do álcool”. (Millan et $a l .$, 1999). Este autor afirma, ainda, que esses dados coincidem com os obtidos em pesquisas realizadas em faculdades de Medicina estrangeiras, apesar das diferenças culturais existentes (Millan, 2005).

\subsection{Consequências da falta de tratamentos dos estudantes universitários}

No trabalho de revisão de literatura anteriormente citado (Hunt et al., 2009), o maior perigo em relação à falta de tratamento adequado aos universitários com algum tipo de doença mental é o suicídio. Sobre esse tema, os autores da revisão citam uma pesquisa realizada por Blanco e cols. em 1990 , que abordou 70 universidades norte-americanas, 
relatando que $8 \%$ de graduandos e $5 \%$ de graduados admitiram terem tentado o suicídio, pelo menos, uma vez na vida.

Hunt e cols. destacaram outra pesquisa que apontou que, de acordo com dados epidemiológicos obtidos entre 2002/3 sobre abuso de álcool e condições correlatas, metade da população de estudantes de universidades norte-americanas se enquadrou, no ano anterior à pesquisa, nos critérios estabelecidos pelo DSM - IV para, pelo menos, um transtorno mental. Os fatores de risco para o suicídio se mostraram maiores entre os estudantes do sexo masculino, enquanto as mulheres apresentaram maiores indicadores de sintomas de depressão e ansiedade. Piores condições de saúde mental foram encontradas entre estudantes com dificuldades relacionais, baixos suportes sociais ou vítimas de violência sexual (Hunt et al., 2009).

Ademais, dados obtidos pela National Survey of College Couseling Center Directors, publicados naquele ano, apontaram que apenas $20 \%$ dos estudantes que cometeram suicídio haviam buscado ajuda nos centros de aconselhamentos de suas faculdades. Este estudo contou com 157 estudantes universitários de diversos anos da graduação, entre homens, mulheres, caucasianos, asiáticos, negros e hispânicos, com idade média de 20 anos e indicadores de elevado risco ao suicídio (ideação suicida atual, histórico de tentativa de suicídio, depressão e abuso de álcool). Desses, $25 \%$ apresentaram depressão de moderada a severa, e 11\% depressão severa. Alto risco para alcoolismo foi apresentado por $45 \%$ dos estudantes. Em relação à ideação suicida, $70 \%$ desses estudantes a apresentaram por, pelo menos, vários dias nas duas semanas que antecederam a pesquisa e 30,6\% reportaram uma tentativa de suicídio ao longo da vida. Esse estudo que buscou investigar as barreiras à procura de auxílio psicológico entre estudantes universitários com alto risco para suicídio citou que, de acordo com dados nacionais norte-americanos, aproximadamente, $6 \%$ da população estudantil universitária consideraram seriamente cometer suicídio e 1\% efetivaram (Czyz et al., 2013).

Sobre o suicídio na FMUSP, Millan relata um declínio dessa taxa na universidade, que, antes da criação do GRAPAL (Grupo de Apoio Psicológico ao Aluno, conforme item 1.5, adiante), era de 39/100.000 alunos/ano, número de 4 a 5 vezes maior do que o índice da população do Município de São Paulo. Entre os anos de 1986 (quando o GRAPAL foi criado) e 2000, foi registrado um único caso, quando o esperado seria um número seis vezes maior se o índice continuasse o mesmo (Millan, 2005). De 1987 até agora, foi registrado mais um caso de suicídio entre graduandos, ocorrido em 2013. 
Outras consequências decorrentes da falta de tratamentos adequados ao aluno acometido por algum tipo de doença mental são os prejuízos de aprendizagem dos conteúdos acadêmicos, isolamento social e a desistência do curso, sendo esta última especialmente observada entre os estudantes que fazem uso de drogas (Dyrbye et al., 2006, Storrie et al., 2010, Czyz MS et al., 2013).

Alguns estudos demonstraram que constituíam fatores estressores a carga de trabalhos acadêmicos, o rigor do currículo médico, a competitividade, bem como, traços de personalidade, como o perfeccionismo e a ausência de suporte social (Smith et al., 2007, Hefner e Eisenberg, 2009). Esses fatores também foram observados por autores que estudaram a saúde mental dos estudantes de Medicina em universidades brasileiras (Millan et al., 1999, Nogueira-Martins et al., 2004, Baldassim et al., 2006).

Esse dado foi confirmado por pesquisa realizada na Universidade de Iowa, que investigou a presença de quadros de depressão e ansiedade nos alunos do curso médico, e sugeriu que o rigor do currículo médico pode representar um importante fator na prevalência dos sintomas ansiosos e depressivos nestes estudantes durante sua graduação (Smith et al., 2007).

Além desse fator, foram ainda citados como possíveis gatilhos para a doença mental dessa população a diminuição das horas de lazer, as perdas em relação ao convívio com antigos amigos e namorada(o), o contato com a morte, as características de personalidade, como o perfeccionismo e a competitividade, a necessidade de realizar vários processos de adaptação relacionados à mudança de cidade, aos novos sistemas de ensino e avaliação, e aos novos amigos e professores e "a ruptura da idealização do curso e a crescente conscientização dos problemas da profissão médica" (Millan et al., 1999).

\subsection{Acesso a tratamentos especializados}

Pesquisa realizada em escolas nos EUA sobre o acesso a tratamentos psicológicos por estudantes universitários, indicou que a maioria dos estudantes com doenças psiquiátricas, inclusive os com alto risco de suicídio, não recebeu nenhum atendimento em saúde mental e apenas $34 \%$ a $36 \%$ de estudantes com transtorno do humor e $4 \%$ a $5 \%$ de estudantes com quadro de abuso de drogas receberam algum tipo de tratamento (Czyz et al., 2013). 
Um estudo revelou que, apesar de constatada a demanda de cuidados com a saúde física e mental, poucos estudantes acessam ou usam os serviços de saúde necessários (Roberts et al., 2000). Hunt e cols. confirmam esse dado, destacando a preocupação concernente ao tratamento e atendimento das necessidades dessa população, uma vez que inúmeras pesquisas indicaram que a prevalência de doenças mentais não tratadas é maior na população estudantil do que na população em geral (Hunt et al., 2009).

Assim, os estudantes universitários estariam recebendo menos auxílio psicológico do que o necessário (Eisemberg et al., 2012). Na revisão promovida por Hunt e cols., apenas $24 \%$ dos universitários norte-americanos com diagnóstico de depressão receberam algum tipo de tratamento, o mesmo ocorrendo com menos de $20 \%$ dos que apresentaram ansiedade (Hunt et al., 2009).

Um estudo realizado com 322 alunos de uma escola médica particular nos EUA encontrou $15,2 \%$ dos estudantes com diagnóstico de depressão, dentre os quais 10 (ou 20,4\% desses) reportaram ideação suicida durante o curso médico. Os autores relataram que, apesar de terem sido disponibilizados serviços de saúde mental com garantia de confidencialidade e acesso a medicamentos psiquiátricos, os estudantes deprimidos não buscaram o tratamento adequado e necessário (Tjia et al., 2005).

Embora a maioria dos estudantes universitários saiba que desenvolveu algum tipo de doença mental, os baixos índices de procura por tratamentos remetem a uma prevalência e persistência dessas doenças, fazendo com que essa população conviva com essas patologias por um período considerado demasiadamente longo.

Esta foi a conclusão de uma pesquisa realizada sobre a persistência de doenças mentais e demandas psicológicas de uma população universitária em uma grande universidade pública nos EUA. Esse estudo que adotou o método transversal, e realizou a coleta de dados por intermédio da WEB em duas etapas, sendo a primeira em 2005 e a segunda, como follow up, em 2007, constatou que metade dos estudantes sofria de, pelo menos, uma doença mental na primeira ou na segunda etapa. Dentre aqueles que apresentaram alguma doença mental em 2005, 60\% ainda apresentavam, pelo menos, uma doença mental dois anos depois. Essa pesquisa indicou, ainda, que, dentre os estudantes que apresentaram alguma doença mental nos dois pontos da pesquisa (2005 e 2007), menos da metade recebeu algum tipo de tratamento durante esse período (Zivin et al., 2009). 


\subsubsection{Barreiras}

As barreiras que dificultam ou impedem o acesso a esses serviços são de ordem variada, como mostram diversos estudos realizados em vários países e também no Brasil. De acordo com as pesquisas estrangeiras consultadas, o estigma em relação à doença mental e a seu tratamento aparece como uma das barreiras mais alegadas, principalmente pelos estudantes de Medicina.

Um estudo publicado em 2003 com estudantes de uma escola médica de Manchester, Inglaterra, relatou que, embora os alunos reconheçam o estresse provocado pelo rigor do curso, há um estigma que conduz a uma espécie de norma compartilhada pelo grupo de estudantes e, até mesmo, entre médicos já graduados, que associa o estresse e as doenças mentais à fraqueza de caráter, e a implicações negativas e a prejuízos ao progresso e ao sucesso na carreira médica (Chew-Graham et al., 2003).

$\mathrm{O}$ receio da estigmatização em relação à doença mental alcança, até mesmo, os protocolos de pesquisa. Estudo realizado com 400 estudantes de Medicina convidados a responder o BDI (Inventário de Depressão de Beck), nos Estados Unidos, relatou que, dentre os 191 (48\%) alunos que responderam o questionário, 160 responderam de forma completa e 31 (ou 19\%) admitiram preocupações com o sigilo dos resultados da pesquisa, o que levou $10 \%$ deles a admitir que não responderam às questões de forma honesta e verdadeira (Levine et al., 2003).

O estigma em relação à doença mental e sua associação à fraqueza ou fragilidade também foi identificada em pesquisa realizada numa universidade brasileira, que apontou que, aproximadamente, um quinto dos estudantes do curso apresentaram escores positivos para ansiedade alta em teste a que foram submetidos, sendo que a expectativa de que esses procurassem algum tipo de ajuda era baixa em razão da própria doença. Afirmou o autor que não era difícil supor que muitos desses alunos não procurassem ajuda ou tratamento, "permanecendo menos pragmáticos e pessimistas pelo próprio distúrbio, ou ainda por preconceito, com receio de serem julgados "fracos" ou de que "alguém fique sabendo" (Baldassin, 2006).

Já em relação a estudantes universitários de diversos cursos (não somente de escolas médicas), como visto por meio da supracitada revisão realizada por Hunt e cols., as principais barreiras à procura por auxílio psicológico apontadas por esta população foram 
a falta de tempo, preocupações com a privacidade, falta de abertura emocional ou restrições financeiras. Neste levantamento, os autores ainda encontraram a falta de percepção da necessidade de ajuda, desconhecimento sobre as coberturas do seguro saúde em relação ao tratamento psicológico e o ceticismo acerca da eficácia dos tratamentos como causas impeditivas de busca desse. Foi também relatado que a busca por auxílio psicológico era menor entre os estudantes de origem socioeconômica inferior, estrangeiros (latinos) e asiáticos. As atitudes de estigmatização dos estudantes sobre as doenças mentais estavam associadas a uma menor procura por serviços especializados. Uma vez que $90 \%$ dos estudantes tinham seguro ou acesso a serviços gratuitos, verificouse que a escassez de recursos financeiros não era uma barreira. (Hunt et al., 2009).

Um estudo realizado com 2.785 estudantes universitários na America do Norte com escores positivos para ansiedade e depressão, apontou que de $37 \%$ a $84 \%$ dos estudantes, dependendo da patologia, não buscaram auxílio psicológico por não perceberem sua própria doença, por não conhecerem os serviços disponíveis ou coberturas do seguro saúde, por ceticismo acerca do tratamento, em razão do nível socioeconômico de origem (baixo), ou por serem de origem asiática. Os autores dessa pesquisa referem que é necessária a adoção de iniciativas para promoção do acesso desses estudantes aos serviços de saúde mental, o que pode ser significativamente benéfico à saúde dessa população (Eisemberg et al., 2007).

Outra pesquisa confirmou que as barreiras mais mencionadas para justificar a atitude de não procurar auxílio ou tratamento psicológicos por estudantes universitários foram, em primeiro lugar, a falta de necessidade de tratamentos em razão de seus problemas serem de menor importância ou transitórios, justificativa arguida por $66 \%$ dos estudantes. Em segundo lugar, foi alegada a falta de tempo por $26,8 \%$ dos alunos e $18 \%$ afirmaram preferir lidar com seus problemas sozinhos. O estigma e o desconforto em discutir seus problemas com um profissional da saúde mental foram mencionados por 12\% dos estudantes (Czyz et al., 2013).

Em relação às variáveis gênero e raça, as barreiras mencionadas ficaram assim compreendidas: uma grande proporção de mulheres (33\%) mencionou a falta de tempo como a principal barreira, enquanto apenas $13 \%$ dos homens a mencionaram. Da mesma forma, os negros, asiáticos e outras raças citaram a falta de tempo $(52,2 \%)$ mais que os caucasianos (20\%) (Czyz et al., 2013). 
Em relação às patologias, quanto maior a severidade de abuso de álcool pelos estudantes, mais vezes era mencionada a falta de necessidade de buscar tratamentos, o mesmo ocorrendo em relação aos estudantes com sintomas depressivos menos severos. Assim, a falta de percepção da necessidade de busca de tratamentos em saúde mental por estudantes com alto risco de suicídio também foi identificada como a barreira mais mencionada. Os estudantes com alto risco de suicídio que percebiam a necessidade de atendimentos especializados tinham 4 vezes mais chances de acesso a esses serviços do que os que não tinham tal percepção (Czyz et al., 2013).

A falta de tratamentos adequados não se restringe às doenças psicológicas, estendese às físicas também. Pesquisa, publicada no ano de 2000 pelo Departamento de Psiquiatria da Escola de Medicina da Universidade do Novo México, EUA, avaliou 1.027 estudantes de Medicina de nove universidades norte-americanas com o objetivo de documentar o acesso, tratamentos e cuidados com a saúde adotados por esses estudantes durante o curso médico (Roberts et al., 2000).

Dentre os achados dessa pesquisa, foi constatado que $90 \%$ dos estudantes apresentaram a necessidade de receber algum tratamento de saúde durante os anos da graduação e que, apesar de $96 \%$ dos estudantes terem seguro saúde, $48 \%$ relataram dificuldades em obter o tratamento necessário. As dificuldades apontadas foram: falta de tempo (37\%), preocupação com o custo (28\%), muito tempo de espera (24\%), preocupação com a confidencialidade (15\%), falta de acesso a serviços de saúde (4\%) e outras razões $(4 \%)$.

Apesar de chamar a atenção a alta prevalência constatada do seguro saúde pelos estudantes de Medicina norte-americanos, a grande maioria encontrou significativas barreiras de acesso a esses serviços, sendo que o nível de inacessibilidade a esses serviços se mostrou $20 \%$ maior que o da população em geral, equiparando-se somente às taxas encontradas para uma população com doenças de alto risco. Ademais, a maioria dos estudantes da amostra, incluindo três quartos de estudantes de uma das nove universidades que compõem o estudo, escolheu não buscar qualquer tipo de tratamento durante o curso, sendo a justificativa mais adotada a falta de tempo por conta das exigências da grade curricular.

Outro fator preocupante avaliado nesta pesquisa se refere ao fato de quase dois terços $(63 \%)$ dos estudantes afirmarem ter procurado os próprios colegas ou realizado consultas informais com esses a fim de obterem diagnósticos, medicamentos e testes 
laboratoriais. Para os pesquisadores, essa atitude, que parece crescer com o avanço do curso e a chegada dos estudantes na fase clínica, traz sérias implicações, como a crença de que os cuidados pessoais com a saúde podem ser realizados à margem dos limites profissionais usuais, podendo incrementar os autodiagnósticos e autoprescrições, além de impedir a formação da relação médico-paciente, dentre outras consequências.

Esses autores destacam que as experiências pessoais de cuidado com a saúde trazem outras implicações com a futura prática médica e atitudes adotadas na relação médicopaciente. Eles apontam que está emergindo uma literatura baseada em dados empíricos que indica que os comportamentos de cuidados com a própria saúde adotados pelos médicos são os mesmos utilizados em sua prática clínica, como os relacionados ao uso de tabaco, álcool, exercícios físicos e controle de peso. Baseados nessas considerações, concluem os pesquisadores que o modo como estudantes de Medicina experimentam os cuidados com a própria saúde pode influir de forma duradoura em seu padrão de atendimento clínico profissional (Roberts et al., 2000).

A respeito da saúde do médico e a forma como esse se relaciona com sua doença muito já se estudou a respeito. Dentre os vários e importantes estudos sobre o tema, foi observado que os médicos apresentam, de maneira geral, uma resistência em buscar tratamentos adequados e especializados, e são, por isso, muitas vezes, considerados maus pacientes - "o médico é o pior paciente" (Meleiro, 1999).

Embora o estudo realizado por essa autora comparasse o comportamento entre pacientes (médicos, advogados e engenheiros) com doenças cardíacas, não passou despercebida as observações acerca da resistência também em relação às doenças psíquicas apresentadas pelos profissionais da área médica. Assim, em $O$ médico enquanto paciente, Meleiro (1999) relata esse fenômeno de resistência, observado por outro colega, no serviço denominado Disque-Psiquiatria que existiu no Instituto de Psiquiatria do HC - FMUSP. Conforme seu relato, 20\% “das ligações para informações sobre determinadas doenças psiquiátricas eram, na verdade, autoconsultas. A pessoa (médico) ligava, começava o discurso na terceira pessoa, e gradativamente passava a utilizar a primeira pessoa". A conduta adotada por esse serviço nessas situações era orientar o médico a buscar auxílio profissional psiquiátrico, em relação a qual alguns dos médicos consulentes pareciam ficar ofendidos.

Esse tema, também abordado em artigo de Mello Filho, relaciona a passagem do médico para o papel de paciente a uma crise de identidade, embora, citando Nogueira- 
Martins, ressalve: "Providenciar tratamento para estes médicos não é tarefa fácil, dada a dificuldade em aceitar o papel de pacientes. Quando em tratamento, no entanto, o prognóstico é melhor que o da população em geral" (Alves, H., Nogueira-Martins e outros, 2005).

Interessante estudo abordou a questão acerca das mudanças na demanda de estudantes por serviços psicológicos registrados pelos centros de aconselhamento e serviços de saúde mental de dez universidades norte-americanas. Dentre os resultados dessa pesquisa, foi observado o aumento do número de estudantes com depressão e ansiedade, da gravidade dos sintomas e da presença de doenças mentais severas. Foi apontada, também, a necessidade desses centros em atender às demandas desses estudantes com a adoção de determinadas medidas e intervenções, dentre as quais se destaca a de investimento em profissionais especializados (Eisemberg, Hunt, Watkins, 2011).

Este entendimento e proposição foi, também, confirmado por outra pesquisa anteriormente citada, que indicou que mais de $90 \%$ dos diretores de Centros de Aconselhamento Universitários pesquisados informaram que investimentos em serviços que atendam as demandas dos estudantes são necessários para oferecer tratamentos adequados a essa crescente população (Czyz et al., 2013).

Conforme descrito por Millan e cols., a personalidade do estudante de Medicina da FMUSP é marcada por doses de altruísmo, competitividade, perfeccionismo e traços obsessivos (Millan, 1999) e, de acordo com Nogueira-Martins, "muitas das características psicodinâmicas que conduzem as pessoas para a carreira médica também as predispõem para distúrbios emocionais e psiquiátricos. Estas características incluem compulsividade, rigidez, controle sobre as emoções, retardo de gratificações e formação de fantasias irrealistas sobre o futuro." Esse autor, nesse artigo, ainda destaca revisão realizada por Johnson (1991), em que aponta que as experiências de vida são importantes na determinação da vulnerabilidade do médico ao estresse ocupacional (NogueiraMartins, 1996).

\subsection{O GRAPAL}

Considerando-se esses e outros estudos e pesquisas realizadas(os) anteriormente sobre o tema, ficou identificada a necessidade de apoio psicológico a alunos de Medicina. 
Por conta do reconhecimento dessa demanda, foi criado, na Faculdade de Medicina da USP, o GRAPAL - Grupo de Assistência Psicológica ao Aluno da Faculdade de Medicina da Universidade de São Paulo - que iniciou suas atividades em 1986, com o objetivo de oferecer um espaço no qual fosse possível atender os estudantes de Medicina em relação às suas demandas emocionais e psicológicas (Millan, 2008).

Conforme dados extraídos do Relatório Anual de 2014 do Grupo de Assistência Psicológica ao Aluno da Faculdade de Medicina da Universidade de São Paulo, desde a sua criação, o GRAPAL realizou mais de 26.453 consultas a estudantes. Dentre elas, 20.163 eram a graduandos da Medicina, 3.457 eram a residentes e 2.816 aos que cursavam Fonoaudiologia, Fisioterapia ou Terapia Ocupacional.

Porém, confirmando as pesquisas que apontam a dificuldade de acesso dos estudantes de Medicina aos serviços de saúde mental, o GRAPAL refere que, embora ofereça gratuitamente a esses estudantes a oportunidade de terem reconhecidas possíveis psicopatologias e dificuldades emocionais que possam prejudicar de alguma forma sua vida pessoal, acadêmica e formação profissional, bem como lhes ofereça tratamento, atendimento, e apoio psicológico e psiquiátrico adequado à sua demanda, apenas uma parte desses alunos procura e/ou utiliza esse serviço.

Uma outra parte dos estudantes, ainda não identificada, não procura nem utiliza os serviços oferecidos pelo GRAPAL, apesar dos benefícios que poderia usufruir em razão da existência ou surgimento de sintomas de ansiedade, depressão ou de dificuldades emocionais e psicológicas ao longo do curso de Medicina.

O desinteresse e/ou evitação por parte desses alunos por esse auxílio psicológico e psiquiátrico oferecido gratuitamente poderia ser atribuído à manifestação de um fenômeno psíquico cunhado por S. Freud como "resistência", uma defesa psíquica inconsciente.

\subsection{O funcionamento psíquico e a resistência - breve exposição}

De acordo com o Dicionário de Psicanálise, define-se como resistência "a tudo que nos atos e palavras do analisando, durante o tratamento psicanalítico, se opõe ao acesso deste ao seu inconsciente. Por extensão, Freud falou de resistência à psicanálise para designar uma atitude de oposição às suas descobertas na medida em que elas revelavam 
desejos inconscientes e infligiam ao homem um vexame psicológico" (La Planche e Pontalis, 2000).

Assim, o inconsciente pode ser definido como o detentor de concepções latentes que se supõe estarem presentes na mente sem que o indivíduo as conheça ou delas se dê conta. Esse conceito se contrapõe ao de consciente, utilizado por Freud para referir-se às concepções e ideias que estão presentes na consciência do indivíduo e das quais ele se dá conta e tem conhecimento. "Assim, uma concepção inconsciente é uma concepção da qual não estamos cientes, mas cuja existência, não obstante, estamos prontos a admitir, devido a outras provas ou sinais" (Freud, 1912). Os sinais da ação inconsciente mais comuns e perceptíveis foram descritos por Freud no artigo "Sobre a Psicopatologia da vida cotidiana" (Freud, 1901); são os esquecimentos de nomes próprios, as parapraxias ou atos falhos, em que um indivíduo troca uma palavra por outra, comunicando algo diferente do que conscientemente se propôs a dizer, o que revelaria uma ideia ou um desejo inconsciente que acabou por se manifestar.

Também é possível que uma ideia que tenha se tornado inconsciente por força da repressão possa se tornar consciente, mas, para isso, é necessária uma grande quantidade de esforço, capaz de vencer a sensação imediata de repulsão que tem de ser dominada, e que foi denominada "resistência" (Freud, 1912).

A resistência é, então, a força que opera a repressão e outros mecanismos de defesa, que mantém inconscientes e reprimidos todas as ideias, os conflitos, os desejos e os impulsos que não podem se tornar conscientes, sob pena de fazer emergir (mais) um sofrimento no indivíduo.

A resistência foi, inicialmente, percebida e conceituada por Freud em Estudos sobre a histeria, artigo que cita e enumera diversos fenômenos clínicos de resistência. Nesse artigo, escrito no início do desenvolvimento de sua teoria, Freud concebia a resistência como uma força egoica contrária ao trabalho de rememoração por ele exigido durante o tratamento, que aumentava na medida em que o sujeito recuperava as lembranças que mais se aproximavam do núcleo patogênico da neurose, consistente num agrupamento de lembranças interassociadas e recalcadas por serem repulsivas à consciência e à aceitação pelo sujeito (Freud, 1895).

Com o amadurecimento de sua teoria, a resistência passou a ser compreendida como um mecanismo de defesa que se apresenta de cinco maneiras, sendo três delas ligadas ao ego, como o recalque (repressão), a transferência e os denominados ganhos secundários 
da doença, que torna o sintoma parte integrante e sintônica do ego, e que impede ou dificulta a cura. As outras duas formas de resistência são a compulsão à repetição e a reação terapêutica negativa (Freud, 1996).

O termo "defesa" foi utilizado, pela primeira vez, no artigo de Freud intitulado As neuropsicoses de defesa, de 1894, para descrever a luta do ego contra ideias ou afetos dolorosos ou insuportáveis. Mais tarde, a palavra foi abandonada e, com o decorrer do tempo, substituída por "repressão" (Freud, 1926).

A partir de Inibição, Sintoma e Ansiedade, de 1926, Freud passou a usar o conceito de defesa como uma designação geral para todas as técnicas de que o ego se serve em conflitos que possam redundar em neurose, ao passo que ele reteve "a palavra repressão para aquele método especial de defesa..." (Freud, 1926).

Por sua vez, Anna Freud apontou a existência de nove métodos ou mecanismos de defesas diferentes à disposição do ego, cuja finalidade é o combate à vida instintiva, sendo os mais conhecidos: a regressão, a repressão, a formação reativa, a anulação, a projeção, a introjeção, a identificação com o agressor e, ainda, a sublimação ou o deslocamento dos anseios instintivos, ressaltando que este pertence mais ao estudo da mente normal do que ao da neurose (Freud, 1996).

Tratando sobre a análise do ego, ela ainda ressalta a dificuldade do ego em trazer à consciência as suas partes inconscientes, e afirma que "tudo o que provém do ego é também uma resistência, em todos os sentidos da palavra: uma força dirigida contra a emergência do inconsciente e, por conseguinte, contra o trabalho do analista" (Freud, 1996).

Dessa forma, a resistência pode ser compreendida como todo mecanismo de que se utiliza o ego para combater e impedir toda ação ou processo que, como o analítico, busque trazer à consciência conteúdos imersos no inconsciente. Nesse sentido, Freud afirma que "Os mecanismos de defesa contra perigos antigos retornam no tratamento sob a forma de resistência à cura, e isto porque a cura também é considerada pelo ego como uma forma de perigo" (Freud, 1937).

Em relação ao uso da palavra "cura", Winnicott aponta que, em sua etimologia, a palavra cura significava "cuidado". Posteriormente, essa palavra passou a significar a erradicação da doença e da sua causa. Esse autor afirma que cabe aos médicos impedir que os dois sentidos da palavra cura sejam completamente dissociados. De qualquer maneira, ele afirma que é necessário, para que a cura aconteça, a presença da 
confiabilidade e da dependência (Winnicott, 1970) na relação analítica, condições ligadas à presença daquele que, seja médico, analista ou psicoterapeuta, está na condição de prestar o serviço que atenda a demanda do ser humano que sofre. Com isso, Winnicott volta-se à questão da relação transferencial, tão importante e presente em qualquer tipo de tratamento.

A transferência é uma das formas que assume a resistência, sendo designada em psicanálise como um "processo pelo qual os desejos inconscientes se atualizam em determinados objetos no quadro de um certo tipo de relação estabelecida com eles e, eminentemente, no quadro da relação analítica" (La Planche e Pontalis, 2000). Trata-se, aqui, de uma repetição de protótipos infantis vivida com um sentimento de atualidade acentuada em relação ao analista.

Melanie Klein, por meio de sua teoria sobre o desenvolvimento da personalidade e das duas posições do funcionamento psíquico, contribuiu para a compreensão dos mecanismos de defesa, inclusive em relação à questão da resistência. De acordo com sua teoria, nos primeiros meses de vida do ser humano, o ego se caracteriza por sua grande fragilidade, fazendo com que todas as experiências sejam sentidas como boas, se satisfatórias (quando atendidas as necessidades do bebê) ou más, se experimentadas intensas frustrações, desconforto e o medo de aniquilamento (quando suas necessidades não são atendidas adequadamente). Nessa fase, predomina a posição esquizo-paranóide, marcada pela dependência absoluta que tem o ser humano em relação à mãe ou ao seu cuidador, que exerce a função desta. A mãe é percebida e introjetada (representação mental) pelo bebê como um objeto bom, se satisfaz as necessidades da criança; e como um objeto mal e perseguidor se a frustra. Os impulsos amorosos e agressivos, então, são dirigidos ao objeto conforme ele seja percebido como bom ou mau, respectivamente (Klein, 1946).

Quando percebido como objeto mau, este é odiado e atacado em fantasia pelo bebê. Isso o torna um objeto perseguidor, do qual só é possível esperar algum tipo de retaliação. Consequentemente, torna-se necessária a idealização desses objetos, a fim de reduzir-se a ansiedade persecutória originada em razão dos ataques ao objeto (percebido como) mau e perseguidor. Por isso, são comuns, na infância, as fantasias de seres onipotentes, imortais e perfeitos, como os heróis com os quais a criança se identifica e que, onipotentemente, sempre vencem os vilões (Millan, 2005). 
Assim, surge, também, o sentimento de onipotência, que se presta a afastar o sentimento de fragilidade, de dúvida e de insegurança. Nas palavras de Millan, ao explicar esse tipo de funcionamento: "Quando o sentimento de onipotência está presente, desaparecem a dúvida, a insegurança e a necessidade de pedir ajuda a outras pessoas. Há a fantasia primitiva de que querer é poder e nega-se toda e qualquer fragilidade humana. Diante dessa configuração, não há preocupação com o outro e tampouco a possibilidade de sentir gratidão diante de uma ajuda. A inveja e o sadismo aparecem em sua forma mais bruta" (Millan, 2005).

Essas são as características que marcam a posição esquizo-paranoide, uma das duas posições propostas por Klein. A passagem para a outra posição, a posição depressiva, ocorre quando a mãe é capaz de conter os impulsos sádicos e destrutivos do bebê, bem como, sua voracidade; o que permite a integração dos dois objetos que foram anteriormente separados entre bom e mau. Isto quer dizer que a criança começa a perceber que o mesmo objeto que lhe frustra (e por isso o odeia) é também o que satisfaz suas necessidades (e por isso, também o ama). Aos poucos, ela vai se dando conta de que atacar a mãe ou o objeto amado lhe desperta um sentimento de culpa, e que, se conseguir tolerálo, poderá realizar movimentos reparatórios em relação a esse objeto. Porém, se a criança não conseguir suportar a culpa, ela poderá retornar à posição esquizo-paranoide.

A posição depressiva se caracteriza pela integração dos impulsos amorosos e agressivos e "a noção de responsabilidade pelos próprios atos, o respeito e a preocupação com os outros e uma maior segurança pelos recursos existentes. Aceitamse, então, os limites, internos e externos, sem que isso implique conformismo, e surge a capacidade de amar o objeto sem o manto da idealização. A autoestima estabelece-se de forma consistente e há maior flexibilidade em relação a si e aos outros. Desenvolve-se, então, a capacidade de sentir gratidão, a generosidade e o altruísmo, que constituem a semente da vocação médica" (Millan, 2005).

É importante ressaltar que essas posições se alternam e oscilam ao longo da vida do indivíduo, especialmente quando este se encontra sob certas circunstâncias desfavoráveis; não sendo certo afirmar que, uma vez que o sujeito tenha atingido a posição depressiva, nunca mais ele retornará à esquizo-paranoide (Millan, 2005). Porém, com o amadurecimento da personalidade, é esperado que os indivíduos permaneçam mais tempo 
na posição depressiva do que na esquizo-paranoide e que, quando estejam regredidos a esta última, possam dela se recuperar e retomar à depressiva.

Considerando essas duas posições psíquicas, Klein descreveu alguns mecanismos de defesa a elas inerentes observados conforme o tipo de ansiedade experimentada pelo ego. Dentre as diversas defesas apresentadas pelo indivíduo, destaca-se a defesa maníaca, característica da posição depressiva. Essa autora relata que a defesa maníaca pode assumir “tantas formas que, com certeza, não é fácil postular um mecanismo geral. Mas acredito que temos realmente esse tipo de mecanismo (ainda que suas variedades sejam infinitas) na dominação dos pais internalizados enquanto, ao mesmo tempo, a existência do mundo interno é depreciada e negada" (Klein, 1935).

A autora afirma que o objetivo da defesa maníaca é a busca de um refúgio pelo ego, não só contra a melancolia, mas também contra a ansiedade paranoide que este não consegue controlar (Klein, 1935).

Essa defesa atua por meio da negação da dor e da realidade psíquica, da idealização, do senso de triunfo manifestado pela depreciação e desprezo do objeto, e "utilização do senso de onipotência com o objetivo de controlar e dominar objetos" (Klein, 1935).

A negação, uma das formas da defesa maníaca, foi definida como um processo "pelo qual o sujeito, embora formulando um dos seus desejos, pensamentos ou sentimentos até então recalcado, continua a defender-se dele negando que lhe pertença” (La Planche e Pontalis, 2000).

Já a racionalização, outra forma bem comum de mecanismo de defesa por meio do qual se manifesta a resistência, é conceituada como um "processo pelo qual o sujeito procura apresentar uma explicação coerente do ponto de vista lógico, ou aceitável do ponto de vista moral, para uma atitude, uma ação, uma ideia, um sentimento etc., cujos motivos verdadeiros não percebe; ...” (La Planche e Pontalis, 2000). 
2 OBJETIVOS 


\section{OBJETIVOS}

\subsection{Objetivos principais}

1. Observar se há manifestação da resistência, por parte dos alunos da graduação do curso de Medicina, em relação à busca por auxílio psicológico;

2. Identificar prováveis aspectos psíquicos que possam estar relacionados à resistência e à sua expressão.

\subsection{Objetivos específicos}

1. Estimar a prevalência de depressão e ansiedade entre os graduandos de Medicina por intermédio dos instrumentos Inventário de Ansiedade de Beck (BAI) e Inventário de Depressão de Beck (BDI);

2. Avaliar os níveis dos sintomas ansiosos e depressivos com as variáveis ciclo da graduação e gênero;

3. Estimar a proporção de alunos que apresentam algum tipo de necessidade de auxílio ou tratamento em saúde mental e não o procuram, e

4. Investigar se existe relação entre a manifestação dos sintomas ansiosos e depressivos e a resistência em busca de auxílio psicológico. 


\section{CASUÍSTICA E MÉTODOS}

\subsection{Delineamento do estudo}

Esse é um estudo devidamente aprovado pelo Comitê de Ética em Pesquisa da Faculdade de Medicina da Universidade de São Paulo (Anexo C) consistente num estudo transversal, não controlado, de modelo misto de pesquisa, com enfoques quantitativo e qualitativo.

O enfoque quantitativo permeou a pesquisa ao buscar identificar e quantificar os estudantes matriculados na graduação da Faculdade de Medicina da Universidade de São Paulo (FMUSP) no ano de 2012 que apresentavam escores positivos para depressão e ansiedade, por intermédio da aplicação das escalas Beck para depressão (BDI) e ansiedade (BAI), bem como ao procurar identificar quais sujeitos manifestaram, em algum momento da sua graduação, a necessidade de buscar apoio, tratamento ou auxílio psicológico e não o fizeram, e aqueles que, nesse mesmo período, receberam de outrem a recomendação ou indicação para procurar por esse serviço e/ou atendimento e não procuraram.

O método qualitativo foi adotado para, por meio da análise e interpretação do Teste de Apercepção Temática (TAT) de Murray, com base na Teoria Psicanalítica, investigar e apontar os principais conflitos, ansiedades e mecanismos de defesa utilizados pelos sujeitos da pesquisa naquela atividade, que poderiam estar associados à resistência psíquica que dificulta ou impede o acesso desses sujeitos ao tratamento psicológico adequado.

\subsection{População e sujeitos}

A população-alvo consistiu na totalidade dos alunos matriculados do primeiro ao sexto ano da graduação da FMUSP no ano letivo de 2012, composta por 1.034 alunos.

Os sujeitos da pesquisa foram compostos por todos os alunos que, estando presentes em sala de aula no momento da aplicação dos testes, responderam aos BDI, BAI, 
Questões Complementares adequadamente, e concordaram em participar da pesquisa preenchendo e assinando o Termo de Consentimento Livre e Esclarecido.

\subsection{Material}

\subsubsection{Inventário de Depressão de Beck (BDI)}

O Inventário de Depressão de Beck, criado em 1961, é um instrumento autoaplicável, sendo "provavelmente a medida de autoavaliação de depressão mais usada tanto em pesquisa como em clínica" (Gorenstein et al., 2000).

O BDI pode ser empregado em várias propostas, e os autores afirmam que a nota de corte pode variar conforme a proposta do examinador e a amostra. Quando o objetivo for detectar o maior número de sujeitos deprimidos, os pontos de corte devem ser baixados a fim de diminuir os falsos negativos (Cunha, 2001). Essa autora, citando pesquisa de Oliver e Simons, de 1984, afirma que esses pesquisadores acreditam que, para fins de triagem de população normal, o BDI deveria adotar escore de 18 a 19 para uma estimativa de possível depressão.

O Center for Cognitive Therapy recomenda os seguintes pontos de corte para amostras diagnosticadas: i) $<10=$ sem depressão; ii) de 10 a $18=$ depressão leve a moderada; iii) de 19 a $29=$ depressão moderada a grave, e vi) de 30 a $63=$ depressão grave (Gorenstein et al., 2000).

Assim, para os fins dessa pesquisa, adotamos as seguintes notas de corte: Nível Mínimo: 0-11, Nível Leve: 12-19, Nível Moderado: 20-35 e Nível Grave: 36-63 (Cunha, 2001).

\subsubsection{Inventário de Ansiedade de Beck}

O Inventário de Ansiedade de Beck - BAI - foi criado em 1988 por Beck, Epstein, Brown e Steer, e consiste numa escala de autorrelato para medir a intensidade de sintomas de ansiedade (Cunha, 2001). Embora considerada uma das emoções humanas básicas, a ansiedade e os transtornos de ansiedades podem se apresentar como uma grande 
dificuldade ao indivíduo. Embora os sintomas de ansiedade estejam substancialmente relacionados aos quadros depressivos, a escala BAI foi criada para medir sintomas de ansiedade que são minimamente compartilhados com os de depressão (Cunha, 2001).

O BAI é composto de 21 itens que deverão ser avaliados pelo próprio sujeito numa escala com os seguintes níveis em ordem crescente de intensidade: 0 (sintoma ausente), 1 (sintoma suave), 2 (sintoma moderado) e 4 (sintoma severo).

Da mesma maneira que o BDI, as notas de corte podem ser mudadas conforme o propósito e a amostra da pesquisa, e "para a triagem de casos com possíveis sintomas de ansiedade os limites superiores dos níveis devem ser diminuídos, e, com isso, diminuiria o número de falsos negativos. Para obter uma amostra mais pura, em caso de pesquisa, o procedimento contrário deveria ser adotado, reduzindo o número de falsos positivos" (Cunha, 2001).

Para o fim dessa pesquisa, adotamos os escores: Nível Mínimo: 0-10; Nível Leve: 11-19; Nível Moderado: 20-30 e Nível Grave: 31-63 (Cunha, 2001).

Esses dois inventários de Beck adotados para essa pesquisa são compostos de 21 questões concisas e demoram, em média, cada um deles, de 5 a 10 minutos para serem respondidos.

\subsubsection{Questionário}

O Questionário (Anexo A) foi composto por 4 perguntas dirigidas ao aluno, que apresentou suas respostas com o assinalamento de um "X" nas opções "sim" e "não", e, depois, uma justificativa para a resposta dada. Essas questões foram elaboradas com a finalidade de identificar os alunos que:

(i) em algum momento da graduação, procuraram espontaneamente algum tipo de serviço ou auxílio psicológico, no qual se inclui o GRAPAL, e se concluíram ou não o tratamento procurado, ou o abandonaram antes de sua conclusão; 
(ii) durante a graduação, sentiram vontade ou necessidade de procurar algum profissional (da área de Saúde Mental), diferente de colega, professor ou parente, para conversar sobre alguma questão pessoal que lhe tenha gerado preocupação, insegurança ou ansiedade e NÃO o fizeram, ou, caso tenham procurado esse auxílio, abandonaram o tratamento buscado; e

(iii) receberam algum tipo de sugestão, encaminhamento ou recomendação para iniciar ou fazer algum tipo de psicoterapia ou procurar algum especialista da área da saúde mental e, mesmo assim, não procuram.

\subsubsection{Teste de Apercepção Temática}

O Teste de Apercepção Temática foi criado por Henry Murray, em 1935, e vem sendo, desde então, muito utilizado em pesquisas no Brasil. Esse teste consiste num método utilizado para revelar impulsos, emoções, sentimentos, complexos e conflitos da personalidade, trazendo à consciência tendências reprimidas e inconscientes do sujeito (Murray, 1995).

É um método projetivo para a investigação da personalidade que possibilita a "apreensão profunda de conteúdos dos quais nem sempre o sujeito tem consciência" (Silva, 1989). A "projeção" é um processo natural comum a todos os sujeitos e consiste na forma como "o sujeito percebe o meio ambiente e a ele responde em função de seus interesses, atitudes, hábitos, estados afetivos duradouros ou momentâneos, esperanças, desejos e etc.” (Silva, 1989).

O conceito de "apercepção", de acordo com Bellak, corresponde a uma percepção dinamicamente significativa da realidade, em que é criada uma terceira realidade resultante da interação dinâmica entre os objetos do mundo externo e o mundo interno da pessoa (Silva, 1989).

Embora o teste seja composto por um total de 31 pranchas ou lâminas estampadas com gravuras que retratam diferentes cenas, com diferentes graus de estruturação e realismo (Silva, 1989), ele foi aplicado nesta pesquisa em versão reduzida, adotando-se apenas cinco pranchas (1, 7RH, $8 \mathrm{RM}, 9 \mathrm{MF}$ e $12 \mathrm{H})$ selecionadas por terem conteúdo

pertinente à pesquisa. A aplicação das pranchas selecionadas consistiu na sua apresentação ao sujeito, uma a uma, como um teste de imaginação, em que ele é 
convidado a contar uma história sobre cada prancha, sendo instruído a criar uma história com começo, meio e fim, e descrever o que as personagens estariam pensando e sentindo.

Em função do seu interesse e/ou de sua necessidade de aprovação, o sujeito que se torna comprometido com essa atividade pode dizer coisas sobre as personagens fictícias da história que cria que não poderiam ser ditas por outra maneira, por corresponderem a aspectos de si mesmo. Este procedimento leva “o sujeito a projetar, no sentido geométrico do termo, o seu mundo interno nas situações apresentadas" (Silva, 1989).

A primeira prancha aplicada aos sujeitos que compareceram ao teste foi a prancha 1, denominada "O menino e o violino", que apresenta um estímulo mais estruturado e menos ameaçador, já que a figura retrata uma criança, geralmente percebida como distante do próprio sujeito. A temática mais frequente desta prancha é a relação com a autoridade (pais/professor), atitude frente ao dever, capacidade de realização e de atingir objetivos propostos, e, por ser o primeiro estímulo apresentado ao sujeito, ainda permite investigar a capacidade de adaptação desse frente a uma situação nova (teste/psicoterapia).

Em seguida, foi aplicada a prancha 7RH, denominada "Pai e filho", que aborda a atitude frente à figura paterna e que pode revelar como este é percebido, uma figura autoritária ou de apoio, e dá, ainda, indicações de tendências antissociais e do sujeito frente à psicoterapia.

A terceira prancha aplicada foi a 8RM, chamada "Intervenção cirúrgica". Estímulo forte e desconcertante, que abarca a área da agressividade. A quarta prancha apresentada foi a 9MF, chamada "Duas mulheres na praia", que remete à espionagem, culpa e perseguição, evoca situações frente ao perigo, ao desconhecido e ao proibido, e à psicoterapia e ao autoconhecimento.

A quinta e última prancha a ser aplicada foi a $12 \mathrm{H}$, "O hipnotizador", que evoca situações de passividade e impotência, que podem revelar atitudes frente às figuras de autoridade, à psicoterapia e à situação do teste. 


\subsubsection{O embasamento teórico adotado na interpretação do TAT}

Os resultados dos TATs aplicados foram analisados e interpretados com base na teoria psicanalítica, pelo mesmo indivíduo (psicóloga pesquisadora), a fim de evitar variáveis de concepções teóricas que pudessem estabelecer diferenças significativas na interpretação de cada TAT.

O embasamento teórico adotado fundamentou-se na descrição do funcionamento psíquico proposto por Freud e nas contribuições de Melanie Klein. Assim, consideraramse as instâncias consciente e inconsciente, e a descrição tópica e dinâmica do psiquismo. A descrição tópica se refere às 3 instâncias psíquicas conhecidas como Id, Ego e Superego; e a dinâmica à interação de representações mentais e relações existentes entre elas, conforme se verá mais detalhadamente na Discussão.

\subsection{Procedimento}

\subsubsection{Divulgação da pesquisa}

Inicialmente, procurou-se informar a população da pesquisa a respeito de sua importância, objetivos, métodos, instrumentos e procedimentos, por intermédio de e-mail informativo enviado pela Secretaria de Graduação aos alunos matriculados na graduação no ano letivo de 2012.

Em seguida, foi feito contato pessoal com os coordenadores/professores de cada ano da graduação, a quem foi apresentada a proposta da pesquisa com todas as informações pertinentes e solicitada a concessão de um tempo estimado de 30 minutos, em sala de aula, para que a pesquisa pudesse ser pessoalmente apresentada à população. Obtido o consentimento do professor e/ou coordenador, foi agendada data, dia e horário para a apresentação da pesquisa em sala de aula.

No dia e hora agendados, o(a) aplicador(a) compareceu à sala de aula e, aos alunos presentes, fez uma exposição da pesquisa, fornecendo as informações necessárias e convidando-os a dela participar. Na mesma ocasião, disponibilizou-se a esclarecer as dúvidas que pudessem surgir, inclusive sobre o material adotado (Inventário de Depressão 
e de Ansiedade de Beck, e questionário), expondo-os aos presentes na mesma oportunidade.

Após a apresentação da pesquisa e prestadas as informações necessárias, foi realizada a distribuição do material a cada aluno presente, juntamente com o Termo de Consentimento Livre e Esclarecido. Os alunos foram instruídos a lerem o Termo de Consentimento Livre e Esclarecido, e assiná-lo se estivessem de acordo com esse e, em caso positivo, orientados a preencherem e responderem os testes e questionário distribuídos.

Todos os sujeitos que participaram da pesquisa expressaram seu desejo de participação por meio da assinatura do Termo de Consentimento Livre e Esclarecido (TCLE), redigido de acordo com a Resolução $\mathrm{n}^{\circ}$ 196, de 10 de outubro de 1996, do Conselho Nacional de Saúde. O projeto de pesquisa foi aprovado pelo Comitê de Ética, em sessão ocorrida em 30/03/2012, sob Protocolo $n^{0}$ 104/11. No TCLE, constavam informações e esclarecimentos redigidos de forma didática e sucinta para que os sujeitos pudessem compreender os objetivos da pesquisa e os procedimentos adotados para sua realização a fim de poderem decidir sobre sua participação voluntária nessa. Nele, também constaram todos os possíveis riscos e desconfortos a que os sujeitos estariam expostos, como o leve e passageiro aumento da ansiedade, bem como a possibilidade de serem atendidos por especialistas em caso de necessidade. Para tanto, foram incluídos, no TCLE, as informações de acesso e contatos necessários ao agendamento desse tipo de atendimento.

\subsubsection{Coleta de dados}

\subsubsection{Inventários de Depressão e de Ansiedade de Beck e questionário complementar}

Numa primeira etapa, foram aplicados o Inventário de Depressão de Beck (BDI) e o Inventário de Ansiedade de Beck (BAI), e um Questionário composto por 4 perguntas.

Antes do início e ao longo da aplicação dos referidos testes e questionário, algumas dúvidas surgiram por parte de alguns alunos, referentes à pesquisa e/ou ao preenchimento dos inventários e questões complementares, e essas foram esclarecidas pelo(a) aplicador(a) na mesma oportunidade e no momento em que foram formuladas. 
Prestadas as orientações e os esclarecimentos necessários para o preenchimento dos BDI, BAI e Questões Complementares, foi solicitado aos estudantes que os preenchessem, conforme orientações verbais dadas em sala de aula, que repetiam as orientações por escrito contidas nos próprios instrumentos. As orientações dadas pelo BAI solicitam que o sujeito identifique o quanto tem sido incomodado "por cada sintoma durante a última semana, incluindo hoje”. O BDI recomenda que o sujeito escolha a afirmação que melhor descreve a maneira que "tem se sentido na última semana, incluindo hoje".

Conforme os alunos terminavam o preenchimento, eles acusavam o seu término e o(a) aplicador(a) os recolhia um a um.

Os testes (BAI e BDI) e questionário foram aplicados a todos os alunos da graduação que estavam presentes em sala de aula no momento da aplicação durante o ano letivo de 2012. As datas de aplicação dos testes e questionário foram as seguintes: $1^{\circ}$ ano - turma A - em 07/05/2012, $1^{\circ}$ ano - turma B - em 08/05/2012; $2^{\circ}$ ano - turma A - em 26/03/2012; $2^{\circ}$ ano - turma B - em 27/03/2012; $3^{\circ}$ ano - turma A - em 15/08/2012; $3^{\circ}$ ano - turma B - em 16/08/2012; $4^{\circ}$ ano - turma A - em 22/10/2012; $4^{\circ}$ ano - turma B em 18/07/2012, $5^{\circ}$ ano em 20/10/2012, e $6^{\circ}$ ano em 05/07/2012.

Os testes aplicados nos alunos do primeiro ao quarto ano se realizaram em sala de aula na presença dos respectivos professores, que cederam 30 minutos do início ou do final da aula para este fim. Apenas aos alunos do quinto e sexto anos, em virtude da divisão de suas turmas em "panelas" (grupos de trabalho de 12 a 15 internos, que rodiziam em estágios hospitalares), inerentes ao internato, a aplicação foi realizada durante atividade didática que reuniu, na mesma oportunidade, todos os alunos de cada ano do internato. A aplicação dos testes aos alunos do quinto ano se deu após uma atividade denominada OSCE (Objective Structured Clinical Examination - prova prática com estações no Laboratório de Habilidades da FMUSP) - e aos alunos do sexto ano a aplicação ocorreu antes do início de uma aula de revisão, preparatória para a prova de residência.

\subsubsection{Teste de Apercepção Temática}


Terminada a aplicação do BAI, BDI e questionário complementar em toda população, iniciou-se, então, a segunda fase da pesquisa, em que novos e-mails contendo uma Carta Convite com as informações relativas à aplicação do Teste de Apercepção Temática foram enviados aos sujeitos da pesquisa, convidando-os a participarem dessa nova fase, em data e horário que fossem convenientes a cada participante.

Para isso, foi informado, na Carta Convite (Anexo B), que o referido teste consistia numa atividade de contar histórias sobre cinco gravuras que seriam mostradas ao aluno e que o tempo estimado para a conclusão dessa atividade seria de, aproximadamente, 30 minutos. Foram, ainda, fornecidos os dados de contato da aplicadora, como telefone, celular e e-mail, por intermédio dos quais foram agendados os TATs com os indivíduos que se mostraram interessados em participar.

Cada um dos alunos que aceitou participar desse teste agendou um encontro com a pesquisadora, em dia e horário estabelecido pelo sujeito, de acordo com sua conveniência.

A aplicação das 5 pranchas do TAT demorou, em média, 30 minutos para cada sujeito. Os resultados foram anotados manualmente durante a aplicação, posteriormente, digitados e interpretados pelo pesquisador.

\subsubsection{Análise de dados}

\subsubsection{Tratamento estatístico do BDI e BAI, e questões complementares}

Os Inventários de Depressão e de Ansiedade de Beck, e Questões Complementares foram corrigidos, quantificados e seus resultados inseridos em uma planilha para análise estatística. Considerando-se que os resultados não seguem uma distribuição conhecida e por estarem em escalas de avaliação qualitativas ordinais, adotou-se a análise estatística não paramétrica por meio dos testes U de Mann Whitney, Kruskal-Wallis e QuiQuadrado, com nível de significância de $5 \%(\alpha=0,05)$. Foi utilizado o software estatístico SPSS, versão 16.0, para realização dos testes estatísticos.

Foram feitas comparações e realizados cruzamentos dos dados obtidos, por meio de tabelas de contingência, utilizando-se dois tipos de agrupamento dos sujeitos: por ano e por Ciclo da graduação. O agrupamento dos alunos segundo os anos da graduação ofereceu uma análise mais detalhada e o agrupamento que considerou os Ciclos Básico, 
Clínico e Internato permitiu trabalhar com maior quantidade de sujeitos por grupo $(\mathrm{N}$ maior) do que no agrupamento por ano da graduação, possibilitando uma visão mais geral dos sujeitos da pesquisa.

As análises consideraram os resultados do BAI e BDI em níveis de intensidade de sintomas Mínimo, Leve e Moderado, seguindo os critérios descritos no Manual da Versão em Português das ESCALAS BECK (Cunha, 2001).

Também foi feita análise estatística, por meio do método Kruskal-Wallis, comparando-se, inicialmente, os resultados individuais obtidos do BAI e BDI entre os anos da graduação e, posteriormente, comprando-se esses resultados entre os Ciclos Básico (agrupamentos dos primeiro e segundo anos da graduação), Clínico (agrupamentos dos terceiro e quarto anos da graduação) e Internato (agrupamentos dos quinto e sexto anos da graduação).

Posteriormente, foram realizadas outras comparações e associações de dados com o gênero dos sujeitos, por meio de tabelas de contingência, adotando-se os resultados dos escores apresentados nas escalas BAI e BDI, considerando-se os níveis de sintomas segundo a classificação em níveis Mínimo, Leve e Moderado. Este trabalho não abarcou o nível Grave (BAI = 30 e BDI =35) pela escassez ou ausência de resultados nessa categoria. Foram identificados apenas 3 sujeitos com escores de ansiedade maiores que 30, incluídos na categoria Nível Moderado e nenhum com depressão na categoria nível Grave.

\subsubsection{Questionário}

Da análise das respostas dadas às perguntas contidas no Questionário, foi possível identificar e quantificar os alunos que:

a) Apresentaram demanda para receber auxílio psicológico, assim considerados os alunos que responderam "SIM" a qualquer das questões, afirmando que, em algum momento da graduação, sentiram necessidade de buscar um apoio psicológico e não o fizeram, que procuraram algum tipo de serviço ou auxílio psicológico, no qual se inclui o GRAPAL e não concluíram o tratamento procurado, ou o abandonaram antes de sua conclusão; 
b) Receberam indicação de terceiro(s) para receber auxílio psicológico;

c) Estavam em terapia;

d) Iniciaram e concluíram algum tipo de tratamento psicológico;

e) Iniciaram e não concluíam ou abandonaram algum tipo de tratamento psicológico.

\subsubsection{Análise e interpretação do TAT}

A interpretação das respostas dadas às pranchas do TAT foi realizada de forma livre, enfatizando os aspectos de conteúdo.

$\mathrm{Na}$ análise de conteúdo, é enfocado “o tema levantado pelo indivíduo e o modo como desenvolve o mesmo. Tal enfoque baseia-se na hipótese de que o indivíduo identifica-se com uma (eventualmente mais de uma) personagem, atribuindo a esta suas próprias características e necessidades, além de configurar a situação e demais personagens do modo como configura sua percepção do ambiente e relação com o mesmo" (Silva, 1989).

Nesse sentido, ao explorarem-se os temas desenvolvidos pelo sujeito, é possível investigar-se a dinâmica da sua personalidade em diversas dimensões: sua autopercepção, suas principais necessidades e conflitos, como ele percebe seu ambiente e como pode resolver suas dificuldades (Silva, 1989).

Para fins dessa pesquisa que visa compreender os principais e mais utilizados mecanismos de defesa apresentados pelos sujeitos, foi dada maior ênfase aos conflitos despertados, tipos de ansiedades e defesas predominantes, integração do ego e adequação do superego.

Quanto à integração do ego, buscou-se verificar "o quanto o sujeito está consciente de seus conteúdos e sua capacidade para elaborá-los" (Silva, 1989). A integração do ego foi considerada "boa" quando o sujeito conseguiu manter um bom nível de vocabulário e riqueza de conteúdo das histórias contadas, um uso adequado das defesas, que permitem o aparecimento dos conflitos e aspectos pessoais, e que apresentam um desfecho para a história com um desenlace realista e soluções adequadas.

Foram considerados com "integração razoável do ego" os sujeitos que permitiram que o conflito emergisse, mas que não apresentaram a possibilidade de elaboração desse 
conflito, apresentando desfechos irreais e fantásticos ou dependentes de elementos externos.

"Fraca Integração do ego" foi a classificação atribuída àqueles sujeitos que não permitiram a emergência do conflito em suas histórias, apresentando relatos pobres, descritivos, hesitantes e/ou contraditórios.

Por último, ainda há nessa escala, a desintegração do ego, verificada quando ocorre uma "invasão de conteúdos inconscientes sem qualquer possibilidade de defesa" (Silva, 1989), o que se verifica quando o sujeito apresenta um relato com pouca ou nenhuma relação com o estímulo apresentado por meio da prancha, o que não foi observado em nenhum sujeito desta amostra.

Relativamente à adequação do superego, foi investigada a relação entre a manifestação do impulso e as consequências desta manifestação para o herói (personagem com a qual o sujeito mais se identifica), com o objetivo de avaliar se as consequências são proporcionais ao impulso, isto é, "se o 'castigo' é proporcional ao 'crime”" (Silva, 1989).

Assim, quanto mais grave é a consequência ou o "castigo" em relação ao impulso ou "crime", sendo evidente a desproporção entre eles, mais rígido é considerado o superego. Dessa forma, a adequação do superego pode ser percebida em uma graduação em que se apresenta, num extremo, classificado como "rígido", passando, em seguida, a ser classificado como "atuante", depois, como "flexível” e, no outro extremo, classificado como "frágil". 
4 RESUltados 



\section{RESULTADOS}

\subsection{Resultados do BAI}

Os inventários de ansiedade (BAI) foram respondidos por 439 sujeitos, sendo 195 mulheres e 244 homens, divididos segundo os Ciclos da Graduação da seguinte maneira:

Tabela 1 - Frequência de sujeitos que responderam o BAI em relação aos Ciclos da graduação e o gênero

\begin{tabular}{cccc}
\hline Ciclos & $\begin{array}{c}\text { Feminino } \\
\mathbf{N}(\boldsymbol{\%})\end{array}$ & $\begin{array}{c}\text { Masculino } \\
\mathbf{N}(\%)\end{array}$ & Total \\
\hline Básico & $76(46,9)$ & $86(53,1)$ & 162 \\
Clínico & $57(42,9)$ & $76(57,1)$ & 133 \\
Internato & $62(43,1)$ & $82(56,9)$ & 144 \\
Total & $195(44,4)$ & $244(55,6)$ & 439 \\
\hline
\end{tabular}

Os resultados obtidos por intermédio dos Inventários de Ansiedade de Beck foram analisados conforme a classificação por nível de severidade dos sintomas segundo critério recomendado pela Manual da versão em Português das ESCALAS BECK, (Cunha, 2001) adotando-se os níveis Mínimo (de 0 a 10), Leve (de 11 a 19), Moderado (de 20 a 30) e Grave (de 31 a 63). Contudo, considerando-se a baixa frequência de resultados graves, uma vez que apenas 3 sujeitos apresentaram resultados maiores que 30 (um do primeiro ano com $\mathrm{BAI}=32$, e um do quinto e um do sexto ano com $\mathrm{BAI}=37$ ) incluímos esses na categoria de "Sintomas Moderados/Graves".

Os resultados dos escores de ansiedade entre os três grupos revelaram uma tendência de diminuição da frequência de sujeitos com sintomas em nível Moderado conforme mais avançado era o Ciclo da graduação. Essa associação entre escores e Ciclos foi estatisticamente significativa $(p=0,001)$. Assim, constatou-se um aumento da frequência de sujeitos com sintomas Mínimos de ansiedade e uma redução da frequência de sujeitos com Nível Leve e Moderado, do Ciclo Básico ao Clínico e desse ao Internato (Tabela 2): 
Tabela 2 - Frequência de sujeitos por níveis de sintomas ansiosos segundo os Ciclos da graduação

\begin{tabular}{ccccc}
\hline Ciclos & $\begin{array}{c}\text { Mínimo } \\
\mathbf{n}(\%)\end{array}$ & $\begin{array}{c}\text { Leve } \\
\mathbf{n}(\%)\end{array}$ & $\begin{array}{c}\text { Moderado } \\
\mathbf{n}(\%)\end{array}$ & Total \\
\hline Básico & $118(72,8)$ & $33(20,4)$ & $11(6,8)$ & $162(100)$ \\
Clínico & $107(80,4)$ & $19(14,3)$ & $7(5,3)$ & $133(100)$ \\
Internato & $131(91,0)$ & $7(4,8)$ & $6(4,2)$ & $144(100)$ \\
Total & $356(81,0)$ & $59(13,5)$ & $24(5,5)$ & $439(100)$ \\
\hline$p=0,001$ & & & &
\end{tabular}

Ao compararmos os resultados dos três Ciclos, se percebeu um desequilíbrio na proporção da frequência dos sujeitos com sintomas ansiosos nos Níveis Mínimo e Leve, cuja variação foi de $18,2 \%$ e de $15,6 \%$, respectivamente, enquanto que em relação ao nível Moderado a variação entre os Ciclos foi menor, de 2,6\%.

A distribuição da frequência de sujeitos agrupados segundo o Ciclo da graduação segundo a intensidade dos sintomas ansiosos também se mostrou estatisticamente significativa $(p=0,001)$, especialmente em relação ao internato cujos alunos apresentaram o menor rank médio em intensidade de sintomas (Tabela 3, abaixo).

Tabela 3 - Teste de Kruskal-Wallis para BAI em relação aos Ciclos da graduação

\begin{tabular}{ccccc}
\hline $\begin{array}{c}\text { Ciclo da } \\
\text { Graduação }\end{array}$ & N & Mediana & Rank médio & $\mathbf{Z}$ \\
\hline Básico & 162 & 6,000 & 257,0 & 4,67 \\
Clínico & 133 & 6,000 & 228,8 & 0,95 \\
Internato & 144 & 3,000 & 170,3 & $-5,74$ \\
Total & 439 & & 220,0 & \\
\hline$p<0,001$ & & & &
\end{tabular}

Considerando-se os níveis de intensidade de sintomas segundo o ano da graduação, o quinto ano apresentou a menor e o terceiro ano a maior frequência de sujeitos com sintomas e essa associação se mostrou estatisticamente significativa (Tabela 4). 
Tabela 4 - Intensidade dos sintomas ansiosos em relação aos anos da graduação

\begin{tabular}{ccccc}
\hline $\begin{array}{c}\text { Ano da } \\
\text { Graduação }\end{array}$ & $\begin{array}{c}\text { sintoma mínimo } \\
\mathbf{n}(\%)\end{array}$ & $\begin{array}{c}\text { sintoma leve } \\
\mathbf{n}(\%)\end{array}$ & $\begin{array}{c}\text { sintoma } \\
\text { moderado } \\
\mathbf{n}(\%)\end{array}$ & Total \\
\hline 1 & $50(68,5 \%)$ & $19(26,0 \%)$ & $4(5,5 \%)$ & 73 \\
2 & $68(76,4 \%)$ & $14(15,7 \%)$ & $7(7,9 \%)$ & 89 \\
3 & $35(70,0 \%)$ & $10(20,0 \%)$ & $5(10,0 \%)$ & 50 \\
4 & $72(86,8 \%)$ & $9(10,8 \%)$ & $2(2,4 \%)$ & 83 \\
5 & $80(94,1 \%)$ & $3(3,5 \%)$ & $2(2,4 \%)$ & 85 \\
6 & $51(86,4 \%)$ & $4(6,8 \%)$ & $4(6,8 \%)$ & 59 \\
TOTAL & $356(81,1 \%)$ & $59(13,4 \%)$ & $24(5,5 \%)$ & 439 \\
\hline$p=0,001$ & & &
\end{tabular}

Considerando-se a frequência dos sujeitos com sintomas ansiosos em nível Mínimo e Leve, percebeu-se uma variação entre os anos da graduação de 25,6\% e 22,5\%, respectivamente. A variação da frequência de sujeitos em Nível Moderado se mostrou mais equilibrada, com variação de 7,6\%, sendo que o quarto e quinto anos apresentaram a menor $(2,4 \%$ dos sujeitos) e o terceiro ano a maior frequência $(10 \%)$ de sujeitos ansiosos.

O terceiro ano apresentou a maior frequência de sujeitos com sintomas moderados e a menor de sujeitos com sintomas mínimos, porém foi o ano da graduação com o menor número de sujeitos da amostra, com apenas 50 alunos.

Ao se relacionar os níveis de sintomas ansiosos com o gênero, revelou-se que, de uma forma geral, mais mulheres $(32,9 \%)$ apresentaram sintomas ansiosos em níveis Leve e Moderado que os homens $(13,9 \%)$, sendo essa diferença estatisticamente significativa $(p=0,01)$, conforme Tabela 5, abaixo:

Tabela 5 - Intensidade dos sintomas ansiosos em relação ao gênero

\begin{tabular}{cccc}
\hline $\begin{array}{c}\text { Nível de sintomas } \\
\text { ansiosos }\end{array}$ & $\begin{array}{c}\text { Feminino } \\
\mathbf{n}(\%)\end{array}$ & $\begin{array}{c}\text { Masculino } \\
\mathbf{n}(\%)\end{array}$ & Total \\
\hline Mínimo & $146(74,9 \%)$ & $210(86,1 \%)$ & 356 \\
Leve & $36(26.2 \%)$ & $23(9,4 \%)$ & 59 \\
Moderado & $13(6,7 \%)$ & $11(4,5 \%)$ & 24 \\
Total & $195(100 \%)$ & $244(100 \%)$ & 439 \\
\hline$p=0,01$ & & &
\end{tabular}




\subsection{Resultados do BDI}

O Inventário de depressão (BDI) foi respondido por 437 alunos, sendo 193 mulheres e 244 homens, assim divididos segundo os Ciclos da graduação (Tabela 6):

Tabela 6 - Frequência de sujeitos que responderam o BDI em relação aos Ciclos da graduação e o gênero

\begin{tabular}{cccc}
\hline Ciclos & $\begin{array}{c}\text { Feminino } \\
\mathbf{N}(\%)\end{array}$ & $\begin{array}{c}\text { Masculino } \\
\mathbf{N}(\%)\end{array}$ & $\begin{array}{c}\text { Total } \\
\mathbf{N}\end{array}$ \\
\hline Básico & $76(46,9)$ & $86(53,1)$ & 162 \\
Clínico & $57(42,9)$ & $76(57,1)$ & 133 \\
Internato & $60(42,3)$ & $82(57,7)$ & 142 \\
Total & $193(44,2)$ & $244(55,8)$ & 437 \\
\hline
\end{tabular}

Da mesma forma que os resultados obtidos por intermédio do Inventário Beck de Ansiedade (BAI), os resultados do BDI foram analisados conforme a classificação por nível de severidade dos sintomas segundo critério recomendado pela Manual da versão em Português das ESCALAS BECK, (Cunha, 2001) adotando-se os níveis Mínimo (de 0 a 11), Leve (de 12 a 19), Moderado (de 20 a 35) e Grave (de 36 a 63).

Tabela 7 - Nível de sintomas de depressão segundo o Ciclo da graduação

\begin{tabular}{cccc}
\hline Ciclos & $\begin{array}{c}\text { Mínimo } \\
\mathbf{N}(\%)\end{array}$ & $\begin{array}{c}\text { Leve } \\
\mathbf{N}(\%)\end{array}$ & $\begin{array}{c}\text { Moderado } \\
\mathbf{N}(\%)\end{array}$ \\
\hline Básico & $130(80,3)$ & $26(16,0)$ & $6(3,7)$ \\
Clínico & $99(74,4)$ & $27(20,3)$ & $7(5,3)$ \\
Internato & $120(84,5)$ & $17(12,0)$ & $5(3,5)$ \\
Total & $349(80,0)$ & $70(16,0)$ & $18(4,1)$ \\
\hline$p=0,347$ & & &
\end{tabular}

A Tabela 7, supra, revelou que o Internato apresentou a menor frequência de sujeitos deprimidos que nos demais Ciclos, seguido pelo Ciclo Básico e, depois, pelo Ciclo Clínico. 
A distribuição da frequência de sujeitos conforme a intensidade do sintoma revelou que os internos apresentaram o menor rank médio em depressão, sendo esse resultado considerado significativo estatisticamente $(p=0,011)$, conforme Tabela 8.

Tabela 8 - Teste de Kruskal-Wallis para BDI em relação aos Ciclos da graduação

\begin{tabular}{ccccc}
\hline $\begin{array}{c}\text { Ciclo da } \\
\text { Graduação }\end{array}$ & N & Mediana & Rank médio & $\mathbf{Z}$ \\
\hline Básico & 162 & 5,500 & 221,5 & 0,31 \\
Clínico & 133 & 6,000 & 241,1 & 2,42 \\
Internato & 142 & 5,000 & 195,5 & $-2,70$ \\
Total & 437 & & 219,0 & \\
\hline$p=0,011$ & & & &
\end{tabular}

Da mesma maneira que no agrupamento por Ciclos da graduação, não foi considerada significativa do ponto de vista estatístico a diferença de intensidade de sintomas depressivos entre os sujeitos quando agrupados segundo o ano da graduação, conforme Tabela 9.

Tabela 9 - Intensidade dos sintomas depressivos em relação aos anos da graduação

\begin{tabular}{ccccc}
\hline $\begin{array}{c}\text { Ano da } \\
\text { Graduação }\end{array}$ & $\begin{array}{c}\text { sintoma mínimo } \\
\mathbf{n}(\%)\end{array}$ & $\begin{array}{c}\text { sintoma leve } \\
\mathbf{n}(\%)\end{array}$ & $\begin{array}{c}\text { sintoma } \\
\text { moderado } \\
\mathbf{n}(\%)\end{array}$ & $\begin{array}{c}\text { TOTAL } \\
\mathbf{N}(\%)\end{array}$ \\
\hline 1 & $58(79,5)$ & $11(15,0)$ & $4(5,5)$ & $73(100)$ \\
2 & $72(80,9)$ & $15(16,9)$ & $2(2,2)$ & $89(100)$ \\
3 & $37(74,0)$ & $8(16,0)$ & $5(10,0)$ & $50(100)$ \\
4 & $62(74,7)$ & $19(22,9)$ & $2(2,4)$ & $82(100)$ \\
5 & $75(88,2)$ & $7(8,2)$ & $3(3,6)$ & $84(100)$ \\
6 & $45(79)$ & $10(17,5)$ & $2(3,5)$ & $57(100)$ \\
TOTAL & $349(79,9)$ & $70(16,0)$ & $18(4,1)$ & $437(100)$ \\
\hline$p=0,219$ & & &
\end{tabular}

Esse agrupamento mostrou que, entre os seis anos da graduação, a variação da frequência dos sujeitos com sintomas depressivos em Nível Mínimo (de 14,2\%), e Leve (de $14,7 \%)$, foi maior que a variação encontrada em Nível Moderado (7,8\%). 
$\mathrm{O}$ quinto ano apresentou a menor (8,2\% dos sujeitos) e o quarto ano a maior frequência $(22,9 \%)$ de sujeitos com sintomas Leves. Essa variação não foi estatisticamente significativa $(p=0,219)$.

Apesar desses resultados não revelarem uma tendência de aumento ou redução da frequência dos sintomas depressivos entre os Ciclos ou anos da graduação (Tabelas 7 e 9), a comparação do Ciclo Básico com o Internato apresentou uma redução na frequência de alunos com sintomas leve e moderado entre os internos e um aumento da frequência de sujeitos com sintomas mínimos entre os calouros.

Em relação ao gênero, os resultados do BDI revelaram que, de forma geral, as mulheres apresentaram mais depressão que os homens, uma vez que a frequência de mulheres com sintomas Leves era superior a dos homens e, em nível mínimo, esse resultado se inverteu, sendo a frequência de homens superior que a de mulheres. Essa diferença não foi significativa do ponto de vista estatístico $(p=0,717)$, conforme Tabela 10, abaixo:

Tabela 10 - Intensidade de sintomas depressivos em relação ao gênero

\begin{tabular}{cccc}
\hline $\begin{array}{c}\text { Nível de sintomas } \\
\text { depressivos }\end{array}$ & $\begin{array}{c}\text { Feminino } \\
\mathbf{N}(\%)\end{array}$ & $\begin{array}{c}\text { Masculino } \\
\mathbf{N}(\%)\end{array}$ & $\begin{array}{c}\text { Total } \\
\mathbf{N}(\%)\end{array}$ \\
\hline Mínimo & $151(78,2)$ & $198(81,2)$ & $162(80)$ \\
Leve & $34(17,6)$ & $36(14,8)$ & $70(16,0)$ \\
Moderado & $8(4,2)$ & $10(4,0)$ & $18(4,0)$ \\
Total & 193 & 244 & 437 \\
\hline$p=0,717$ & & &
\end{tabular}

Em relação ao gênero, 13 (ou 6,8\%) mulheres apresentaram escores =20 para ansiedade e 8 (ou 4,2\%) para depressão. Entre os homens, esses índices foram 11 (ou $4,5 \%$ ) e 10 (ou $4,1 \%$ ), respectivamente.

No total, foram identificados 6 sujeitos com depressão e ansiedade em nível moderado, sendo 3 mulheres e 3 homens.

Apresentaram somente sintomas depressivos moderados 12 sujeitos (5 mulheres e 7 homens) e 18 sujeitos tinham escores $=20$ apenas para ansiedade, sendo 10 do sexo feminino e 8 do masculino. 


\subsection{Resultados do questionário}

\subsubsection{Associação dos Ciclos e anos da graduação à demanda por auxílio psicológico}

O Questionário foi respondido por $433(98,4 \%)$ sujeitos que apresentaram resposta válida a, pelo menos, uma das 3 primeiras questões e/ou escolheram uma das duas alternativas constantes na Questão 4.

Os alunos que responderam "SIM" a qualquer uma das três primeiras perguntas foram considerados "com demanda" para receber algum auxílio psicológico. Essa resposta foi dada por 218 (ou 50,3\%) alunos dentre os 433 que responderam o Questionário, distribuídos segundo os Ciclos da graduação conforme Tabela 11, abaixo:

Tabela 11 - Associação da frequência de alunos com demanda para atendimento psicológico (inclusive psiquiátrico) e os Ciclos da graduação

\begin{tabular}{ccc}
\hline Ciclos da Graduação & N & $\begin{array}{c}\text { Alunos com demanda própria para } \\
\text { atendimento psicológico }(\%)\end{array}$ \\
\hline Básico & 161 & $63(39,1)$ \\
Clínico & 132 & $72(54,5)$ \\
Internato & 140 & $83(59,3)$ \\
Total & 433 & $218(50,3)$ \\
\hline$p=0,001$ & &
\end{tabular}

Os resultados apontaram uma tendência de crescimento da demanda por atendimento psicológico conforme mais adiantado era o Ciclo da graduação que cursavam os sujeitos. Quando divididos segundo os anos da graduação (Tabela 12), os sextanistas apresentaram, proporcionalmente em relação aos calouros, quase o dobro de sujeitos interessados em receber algum tipo de auxílio psicológico, diferença considerada significativa estatisticamente $(p=0,001)$. 
Tabela 12 - Associação da frequência de alunos com demanda para auxílio psicológico e os anos da graduação

\begin{tabular}{ccc}
\hline $\begin{array}{c}\text { Ano da } \\
\text { Graduação }\end{array}$ & N & $\begin{array}{c}\text { Alunos com demanda própria para } \\
\text { atendimento psicológico (\%) }\end{array}$ \\
\hline 1 & 72 & $28(38,8)$ \\
2 & 89 & $35(39,3)$ \\
3 & 50 & $17(34,0)$ \\
4 & 82 & $55(67,0)$ \\
5 & 85 & $43(50,6)$ \\
6 & 55 & $40(72,7)$ \\
Total & 433 & $218(50,3)$ \\
\hline$p=0,001$ & &
\end{tabular}

\subsubsection{Associação dos gêneros à demanda por auxílio psicológico}

Em relação ao gênero, dos 433 sujeitos que responderam adequadamente a uma das perguntas do Questionário, 193 (ou 44,6\%) eram mulheres e 240 (ou 55,4\%) homens. Desses, 100 (ou 51,0\%) sujeitos do gênero feminino e 118 (49,0\%) do masculino apresentaram demanda por auxílio psicológico, e essa associação do gênero à demanda ou necessidade de receber algum tipo de auxílio psicológico não se mostrou estatisticamente significativa (Tabela 13, abaixo).

Tabela 13 - Associação do gênero à demanda por auxílio psicológico

\begin{tabular}{cccc}
\hline Demanda & $\begin{array}{c}\text { Feminino } \\
\mathbf{N}(\boldsymbol{\%})\end{array}$ & $\begin{array}{c}\text { Masculino } \\
\mathbf{N}(\boldsymbol{\%})\end{array}$ & Total \\
\hline Sem & $93(49,0)$ & $122(51,0)$ & 215 \\
Com & $100(51,0)$ & $118(49,0)$ & 218 \\
Total & 193 & 240 & 433 \\
\hline$p=0,584$ & & &
\end{tabular}




\subsubsection{Associação da intensidade dos sintomas ansiosos e depressivos à demanda por auxílio psicológico}

Considerando-se os 24 sujeitos com ansiedade em Nível Moderado, nem todos revelaram possuir demanda por auxílio psicológico. Desses, apenas 14 estavam entre os 218 que tinham demanda por auxílio psicológico (Tabela 14), sendo que, dentre esses 14 sujeitos, somente 4 estavam em psicoterapia. Assim, dos 24 sujeitos com transtorno de ansiedade, 20 estavam sem tratamento.

Em relação aos resultados do BDI, dos 18 alunos que apresentaram escores $\geq 20$ para depressão, 11 sujeitos estavam entre os 217 que apresentaram demanda ou interesse em receber algum tipo de auxílio psicológico. Porém, desses 11 alunos, apenas 5 estavam em terapia. Dessa forma, dos 18 sujeitos deprimidos, 13 estavam sem tratamento.

Tabela 14 - Nível de sintomas de ansiedade em relação à demanda por auxílio psicológico

\begin{tabular}{cccc}
\hline $\begin{array}{c}\text { BAI (em nível de } \\
\text { sintoma) }\end{array}$ & $\begin{array}{c}\text { Sem Demanda } \\
\mathbf{N}(\boldsymbol{\%})\end{array}$ & $\begin{array}{c}\text { Com Demanda } \\
\mathbf{N}(\%)\end{array}$ & Total \\
\hline Mínimo & $188(53,7)$ & $162(46,3)$ & 350 \\
Leve & $16(27,6)$ & $42(72,4)$ & 58 \\
Moderado & $10(41,7)$ & $14(58,3)$ & 24 \\
\hline$p=0,001$ & & &
\end{tabular}

Em relação à intensidade dos sintomas, os resultados dos testes mostraram haver menor frequência de sujeitos com demanda por auxílio psicológico quando o nível de ansiedade era Mínimo (46,3\%) e maior frequência quando os níveis de ansiedade aumentavam para Leve $(72,4 \%)$ e Moderado (58,3\%). Contudo, os sujeitos com ansiedade em nível Leve apresentaram, proporcionalmente, maior demanda por auxílio psicológico do que os indivíduos com ansiedade Moderada (e mais severa), e essa diferença foi considerada estatisticamente significativa $(p=0,001)$.

De maneira geral, considerando a intensidade de sintomas ansiosos da amostra estudada, os sujeitos sem demanda por auxílio psicológico apresentaram rank médio menor (196,3) do que os sujeitos que tinham demanda por esse auxílio (rank médio de 236.3). Essa diferença foi significativa estatisticamente $(p=0,001)$ (Tabela 15). 
Tabela 15 - Teste de Kruskal-Wallis para escores de ansiedade e demanda por auxílio psicológico

\begin{tabular}{cccc}
\hline $\begin{array}{c}\text { Demanda por auxílio } \\
\text { psicológico }\end{array}$ & N & Mediana & Rank médio \\
\hline Sem & 214 & 4,000 & 196,4 \\
Com & 218 & 6,000 & 236,3 \\
Total & 432 & & \\
\hline$p=0,001$ & & &
\end{tabular}

Similarmente, a relação entre demanda por auxílio psicológico e os níveis de sintomas depressivos (Tabela 16), repetiu o mesmo movimento observado em relação aos sintomas ansiosos.

Foi percebida uma frequência maior de sujeitos com demanda para auxílio psicológico quando a intensidade dos sintomas depressivos era mais severa (níveis Leve e Moderado), e menor quando os sintomas eram mínimos. Porém, proporcionalmente, os sujeitos com sintomas depressivos Leves apresentaram mais demanda por auxílio psicológico $(68,11 \%)$ do que os alunos com depressão em nível moderado $(61,11 \%)$ e essa foi considerada uma diferença significativa $(p=0,003)$.

Tabela 16 - Níveis de sintomas depressivos em relação à demanda por auxílio psicológico

\begin{tabular}{cccc}
\hline $\begin{array}{c}\text { BDI (em nível de } \\
\text { sintomas) }\end{array}$ & $\begin{array}{c}\text { Sem Demanda } \\
\mathbf{N}(\boldsymbol{\%})\end{array}$ & $\begin{array}{c}\text { Com Demanda } \\
\mathbf{N}(\boldsymbol{\%})\end{array}$ & Total \\
\hline Mínimo & $184(53,6)$ & $159(46,4)$ & 343 \\
Leve & $22(31,9)$ & $47(68,1)$ & 69 \\
Moderado & $7(38,9)$ & $11(61,1)$ & 18 \\
Total & $213(49,5)$ & $217(50,5)$ & 430 \\
\hline$p=0,003$ & & &
\end{tabular}

Da mesma forma, considerando os níveis de sintomas depressivos, os sujeitos sem demanda por auxílio psicológico apresentaram o menor rank médio $(183,8)$, enquanto que os sujeitos com demanda por esse tipo de auxílio apresentaram rank médio de 246,6. Essa diferença foi estatisticamente significativa $(p<0,001)$ (Tabela 17, a seguir). 
Tabela 17 - Teste de Kruskal-Wallis para escores de depressão e demanda por auxílio psicológico

\begin{tabular}{cccc}
\hline $\begin{array}{c}\text { Demanda por auxílio } \\
\text { psicológico }\end{array}$ & N & Mediana & Rank médio \\
\hline Sem & 213 & 4,000 & 183,8 \\
Com & 217 & 7,000 & 246,6 \\
Total & 430 & & 215,5 \\
\hline$p<0,001$ & & &
\end{tabular}

\subsubsection{Associação entre a demanda por auxílio psicológico, o gênero, a intensidade de sintomas e o acesso aos serviços em saúde mental}

Apesar de metade da amostra (218 ou 50,3\%) ter revelado possuir demanda por algum tipo de auxílio psicológico, apenas 72 (ou 16,6\%) sujeitos informaram que já tiveram acesso a algum tipo de atendimento específico nessa área. Desses, 39 (20,2\%) eram mulheres e $33(13,7 \%)$, homens. E essa diferença não se mostrou significativa do ponto de vista estatístico $(p=0,070)$.

Considerando-se os 72 sujeitos que tiveram acesso a algum atendimento em serviço de saúde mental, $42(58,4 \%)$ afirmaram que estavam sendo atendidos, naquela ocasião, em algum tipo de psicoterapia (inclusive atendimentos clínicos ou psiquiátricos), 24 $(33,3 \%)$ afirmaram que já haviam concluído algum tipo de tratamento psicológico e 6 (ou $8,3 \%$ ) indivíduos relataram que iniciaram, mas não concluíram ou abandonaram o tratamento.

Os 42 sujeitos que afirmaram, naquela ocasião, estarem recebendo algum tipo de auxílio psicológico eram predominantemente do gênero feminino e com sintomas ansiosos (Tabela 18) e depressivos (Tabela 19) em nível mínimo.

Tabela 18 - Intensidade dos sintomas ansiosos dos sujeitos em processo psicoterapêutico em relação ao gênero

\begin{tabular}{cccc}
\hline $\begin{array}{c}\text { Intensidade da } \\
\text { ansiedade }\end{array}$ & $\begin{array}{c}\text { Gênero } \\
\text { Feminino } \\
\mathbf{N}(\boldsymbol{\%})\end{array}$ & $\begin{array}{c}\text { Gênero Masculino } \\
\mathbf{N}(\%)\end{array}$ & $\begin{array}{c}\text { Total } \\
\mathbf{N}(\mathbf{1 0 0 \%})\end{array}$ \\
\hline Mínimo & $19(63,3)$ & $11(36,7)$ & 30 \\
Leve & $5(62,5)$ & $3(37,5)$ & 8 \\
Moderado & $2(50,0)$ & $2(50,0)$ & 4 \\
Total & $26(61,9)$ & $16(38,1)$ & 42 \\
\hline$p=0,875$ & & &
\end{tabular}


Em relação aos Níveis de depressão, os 42 sujeitos que estavam recebendo algum auxílio psicológico estavam assim distribuídos, segundo o gênero e a intensidade do sintoma (Tabela 19, abaixo):

Tabela 19 - Intensidade dos sintomas depressivos dos sujeitos em processo psicoterapêutico segundo o gênero

\begin{tabular}{cccc}
\hline $\begin{array}{c}\text { Intensidade de } \\
\text { depressão }\end{array}$ & $\begin{array}{c}\text { Gênero } \\
\text { Feminino } \\
\mathbf{N}(\boldsymbol{\%})\end{array}$ & $\begin{array}{c}\text { Gênero Masculino } \\
\mathbf{N}(\boldsymbol{\%})\end{array}$ & $\begin{array}{c}\text { Total } \\
\mathbf{N}(\mathbf{1 0 0 \%})\end{array}$ \\
\hline Mínimo & $16(64,0)$ & $9(36,0)$ & 25 \\
Leve & $7(58,3)$ & $5(41,7)$ & 12 \\
Moderado & $3(60,0)$ & $2(40,0)$ & 5 \\
Total & $26(61,9)$ & $16(38,1)$ & 42 \\
\hline$p=0,942$ & & &
\end{tabular}

Em relação ao gênero, a frequência de mulheres com ansiedade em nível Mínimo e Leve que acessaram os serviços em saúde mental foi, em média, 25,5\% maior que a dos homens, embora tenha sido igual quando a intensidade dos sintomas ansiosos era em Nível Moderado.

Ao considerarmos os sintomas depressivos, a frequência de mulheres que acessaram os serviços em saúde mental foi maior que a dos homens independentemente da intensidade desses sintomas. Contudo, foi percebida uma tendência de diminuição dessa diferença de acesso a esses serviços entre os gêneros, proporcional ao agravamento dos sintomas da doença (em Nível Mínimo, a frequência de mulheres que estavam em terapia era $28 \%$ maior que a dos homens, em Nível Leve, essa diferença passou a ser de 16,6\% e, em Nível Moderado, 20\%), conforme Tabelas 18 e 19, acima.

Dos 218 sujeitos que apresentaram demanda para receber algum auxílio psicológico, percebeu-se que a frequência dos sujeitos que estavam em terapia aumentava conforme se intensificavam os seus sintomas, tanto ansiosos como depressivos (Tabela 20).

Observou-se, também, que a frequência dos sujeitos com depressão em nível Moderado ( $\geq 20)$ e que estavam em terapia $(45,5 \%)$ era quase 1,5 vezes maior do que a dos sujeitos com igual nível de ansiedade $(28,6 \%)$. 
Tabela 20 - Nível de sintomas ansiosos e depressivos dos sujeitos com demanda por auxílio psicológico em relação ao tratamento psicológico em andamento

\begin{tabular}{ccccccc}
\hline & \multicolumn{3}{c}{ BAI } & \multicolumn{3}{c}{ BDI } \\
\cline { 2 - 7 } Nível de & $\begin{array}{c}\text { Sem } \\
\text { tratamento } \\
\mathbf{N}(\%)\end{array}$ & $\begin{array}{c}\text { Em } \\
\text { tratamento } \\
\mathbf{N}(\%)\end{array}$ & total & $\begin{array}{c}\text { Sem } \\
\text { tratamento } \\
\mathbf{N}(\%)\end{array}$ & $\begin{array}{c}\text { Em } \\
\text { tratamento } \\
\mathbf{N}(\%)\end{array}$ & total \\
\hline Mínimo & $132(81,5)$ & $30(18,5)$ & 162 & $134(84,2)$ & $25(15,7)$ & 159 \\
Leve & $34(81,0)$ & $8(19,0)$ & 42 & $35(74,5)$ & $12(25,5)$ & 47 \\
Moderado & $10(71,4)$ & $4(28,6)$ & 14 & $6(54,5)$ & $5(45,5)$ & 11 \\
Total & 176 & 42 & 218 & 175 & 42 & 217 \\
\hline $\begin{array}{l}p(B A I)=0,0683 \\
p(B D I)=0,036\end{array}$ & & & & & &
\end{tabular}

Não concluíram ou abandonaram o tratamento em saúde mental iniciado 6 sujeitos, sendo 4 do gênero feminino e 2 do masculino. Das 4 mulheres que não concluíram a terapia, 2 mulheres tinham sintomas ansiosos $(\mathrm{BAI}=5$ e 1$)$ e depressivos $(\mathrm{BDI}=1$ e 3$)$ em Nível Mínimo, a terceira aluna apresentou ansiedade Leve (BAI=17) e depressão mínima (BDI=11), e a quarta tinha ansiedade Leve (BAI=13) e depressão moderada (BDI=26). Os dois homens tinham sintomas ansiosos e depressivos em Nível Mínimo (BAI= 3 e 1 e $\mathrm{BDI}=5$ e 2, respectivamente). Essa associação entre gênero e abandono de terapia não foi considerada significativa do ponto de vista estatístico $(p=0,197)$.

Concluíram o tratamento iniciado 24 sujeitos, sendo $9(10,4 \%)$ mulheres e 15 $(13,6 \%)$ homens.

Os sujeitos que responderam "NÃO" às 3 primeiras questões foram considerados como sujeitos que não possuíam demanda ou necessidade de buscar algum tipo de auxílio psicológico (sujeitos "sem demanda") e totalizaram 214 (ou 49,5\%) dos 432 sujeitos que responderam o BAI e 213 (49,2\%) dos 433 sujeitos que responderam o BDI.

Os níveis de sintomas ansiosos e depressivos desses sujeitos constam nas Tabelas 14 e 16. 


\subsubsection{Associação entre os sujeitos que receberam indicação de terceiros para receber auxílio psicológico, o gênero e a intensidade dos sintomas}

A quarta e última pergunta constante do Questionário procurou identificar os alunos que já receberam de terceiros algum tipo de sugestão, encaminhamento ou recomendação para iniciar ou fazer algum tipo de psicoterapia ou para procurar algum especialista da área de saúde mental, e, mesmo assim, não procuraram. Foram consideradas válidas as respostas marcadas por um "X" em uma das duas alternativas: "isso já me aconteceu" ou "isso nunca me aconteceu".

Foram consideradas válidas 429 respostas a essa pergunta, sendo que $66(15,4 \%)$ sujeitos escolheram a alternativa "isso já me aconteceu". Essa resposta foi dada por 30 $(15,7 \%$ ) das 191 mulheres e 36 (ou 15,1\%) dos 238 homens (Tabela 21).

Tabela 21 - Associação do gênero com o recebimento de indicação de terceiros para buscar auxílio psicológico

\begin{tabular}{cccc}
\hline Gênero & $\begin{array}{c}\text { Não recebeu } \\
\mathbf{N}(\%)\end{array}$ & $\begin{array}{c}\text { Recebeu } \\
\mathbf{N}(\%)\end{array}$ & Total \\
\hline Feminino & $161(84,3)$ & $30(15,7)$ & 191 \\
Masculino & $202(84,9)$ & $36(15,1)$ & 238 \\
Total & $363(84,6)$ & $66(15,4)$ & 429 \\
& & & \\
\hline$p=0,868$ & & &
\end{tabular}

A associação entre o recebimento de indicação para procurar ajuda psicológica, e os níveis e sintoma ansiosos mostrou que a maioria dos sujeitos com sintoma em nível moderado $(83,3 \%)$ não recebeu essa recomendação, assim como os sujeitos com igual nível de sintomas depressivos (83,3\%), conforme Tabelas 22 e 23, a seguir. 
Tabela 22 - Frequência de sujeitos que receberam indicação de terceiros para buscar auxílio psicológico e o nível de sintomas ansiosos

\begin{tabular}{cccc}
\hline Intensidade do BAI & $\begin{array}{c}\text { Sem indicação } \\
\mathbf{N}(\boldsymbol{\%})\end{array}$ & $\begin{array}{c}\text { Com indicação } \\
\mathbf{N}(\boldsymbol{\%})\end{array}$ & Total \\
\hline Mínimo & $293(84,4)$ & $54(15,6)$ & 347 \\
Leve & $49(86,0)$ & $8(14)$ & 57 \\
Moderado & $20(83,3)$ & $4(16.7)$ & 24 \\
Total & $362(84,6)$ & $66(15,4)$ & 428 \\
\hline$p=0,943$ & & &
\end{tabular}

Tabela 23 - Frequência de sujeitos que receberam indicação de terceiros para buscar auxílio psicológico e o nível de sintomas depressivos

\begin{tabular}{cccc}
\hline Intensidade do BDI & $\begin{array}{c}\text { Sem indicação } \\
\mathbf{N}(\%)\end{array}$ & $\begin{array}{c}\text { Com indicação } \\
\mathbf{N}(\boldsymbol{\%})\end{array}$ & Total \\
\hline Mínimo & $295(86,8)$ & $45(13,2)$ & 340 \\
Leve & $51(75,0)$ & $17(25,0)$ & 68 \\
Moderado & $15(83,3)$ & $3(16,7)$ & 18 \\
Total & $361(84,7)$ & $65(15,3)$ & 426 \\
\hline$p=0,047$ & & &
\end{tabular}

\subsection{Justificativas dadas às perguntas do questionário}

\subsubsection{Razões para não procurar auxílio psicológico ou não dar sequência ao tratamento (formas de resistência)}

Ao responderem às 3 primeiras perguntas do Questionário, foi solicitado aos participantes que justificassem a alternativa escolhida, caso esta fosse uma resposta negativa à busca por auxílio psicológico ou à conclusão do tratamento iniciado.

As justificativas apresentadas pelos sujeitos foram variadas, e de cunho pessoal e subjetivo, o que impossibilitou sua categorização e a análise estatística dessas. Contudo, foi possível identificar dois tipos de justificativas cuja frequência se destacou em relação às demais, quais sejam: "sem necessidade" (citada 383 vezes) e "sem tempo" (citada 78 vezes). 
A primeira justificativa mais frequente apareceu redigida de formas diferentes, mas com mesmo sentido, como, por exemplo, "não precisei", "não senti necessidade", "não achei que fosse necessário", "não tinha nenhuma queixa", "não tive nenhum problema que justificasse", "não era necessário".

A segunda justificativa mais frequente, "sem tempo", também foi apresentada em formas similares com mesmo sentido, como "não tive tempo", "falta de tempo disponível no programa (da faculdade)", "não tive muito tempo".

As respostas que ensejavam algum tipo de interpretação ou tinham conotação dúbia ou subjetiva não foram computadas, tanto em relação à falta de necessidade: "a graduação se iniciou há pouco", "procurei para saber sobre doença de parente"; como à falta de tempo: "indisponibilidade de horários" (de quem?), "procrastinei o início", “disponibilidade" (de quê?).

Responderam e justificaram, pelo menos, uma das 3 questões 286 sujeitos, dos quais 119 (ou 41,60\%) eram do Ciclo Básico, 84 (ou 29,37\%) do Clínico e 83 (ou $29,02 \%$ ) do Internato.

Além dessas, a terceira justificativa mais utilizada nas 3 primeiras questões foi a "falta de interesse".

Em relação ao abandono do tratamento oferecido pelo GRAPAL (Questão 1), 32 sujeitos alegaram que "Não gostaram do atendimento", justificando esse comportamento por motivos muito variados, alguns objetivos, como a falta de horários disponíveis, e outros de cunho subjetivo, como, por exemplo, a "falta de empatia com os profissionais" ou "por terem ouvido falar que o serviço não era bom" ou, ainda, por "vergonha", "medo de exposição" e "medo do "sigilo".

Em relação ao uso de outros serviços em saúde mental (Questão 2), foram identificadas as seguintes justificativas: "não sei”, "preguiça", "muito caro", “o tratamento é muito demorado", "não pensei sobre a possibilidade", "desconhecimento sobre o assunto", "melhora espontânea do quadro", "falta de estímulo", "falta de segurança", "não achei que faria diferença", "alcancei meus objetivos", "procurei resolver sozinha", "falta de acesso facilitado, não estereotipado" e "falta de iniciativa".

Quanto ao comportamento de não buscar auxílio psicológico profissional, diferente de parentes, colegas e professores (Questão 3), foram identificadas justificativas como "vontade houve que logo passou", "desconhecimento", "não sabia onde ir", "achei tratarse de algo pouco significante e que fosse passar", "melhora do quadro", "consegui lidar 
sozinha", "vergonha", "financeiro", "procurei outras formas mais acessíveis", "melhora das condições predisponentes" e "meu sentimento melhorou sem ajuda profissional".

Considerando os escores de ansiedade e depressão de maior intensidade (níveis Leve/Moderado) e os anos da graduação de alguns sujeitos, foram encontradas as seguintes justificativas:

a) Primeiro ano da graduação:

Uma justificativa apresentada por um dos alunos do primeiro ano, com BAI=30 e $\mathrm{BDI}=22$, para o comportamento de não buscar auxílio psicológico profissional, seja no GRAPAL (questão 1) seja em outro serviço (questão 2), foi: “não foi observada necessidade para tal fim". O mesmo ocorreu com outros 4 calouros com escores de ansiedade iguais a 20, 19 e 18 cada.

Em relação à depressão, foi identificado um aluno com escore igual a 23 cuja justificativa foi "sem tempo" e outro, com escore igual a 21, que alegou: "sem necessidade".

b) Segundo ano da graduação:

Um aluno com BAI=26 e BDI=19 alegou indisponibilidade de horários (para não procurar ajuda no GRAPAL) e "prolongamento de tempo" para justificar o comportamento de não buscar outros serviços em saúde mental (questão 2).

Outro aluno com BAI = 21 e BDI= 17 alegou "desmotivação" (questões 1 e 2).

Um dos sujeitos com BAI=18 e BDI=13 citou "sem tempo", e outros três sujeitos com escores de ansiedade iguais a 22, 19, e 18 cada, utilizaram a falta de necessidade para explicar o comportamento de não buscar auxílio psicológico (questão 2).

Outro aluno do mesmo ano, com escore de depressão igual a 20, afirmou não procurar o GRAPAL porque estava "sem tempo" e que não procurou outros serviços de saúde mental porque "não tinha necessidade".

c) Terceiro ano da graduação:

Um dos alunos com escore de ansiedade igual a 20 alegou "sem tempo" para buscar algum tipo de auxílio psicológico (questão 2) e outro com BAI=23 alegou "não me senti encorajada" (questão 1). 
Quatro sujeitos do gênero feminino que apresentaram escores de depressão igual a 26, 23, 21 e 20 alegaram "falta de tempo", "sem interesse", "sem necessidade" e "não tive motivo", respectivamente, para não procurar o GRAPAL ou qualquer outro serviço de saúde mental.

d) Quarto ano da graduação:

No quarto ano, foi observada uma aluna com BAI=17 que alegou não ter procurado o GRAPAL por não sentir necessidade (não respondeu as outras questões) e um aluno com escore de ansiedade igual a 22 alegou que não procurou nem o GRAPAL nem outro serviço de saúde mental porque não sentia necessidade.

Um aluno com BDI=17 disse não procurar serviço de saúde mental (incluindo o GRAPAL) por sentir “melhora nas condições predisponentes”.

e) Quinto ano da graduação:

No quinto ano, um aluno com escore de ansiedade igual a 20 justificou "não precisei" e outro com escore de depressão igual a 17 citou a "falta de interesse" para não buscarem auxílio psicológico profissional no GRAPAL ou em outros serviços especializados.

f) Sexto ano da graduação:

Uma aluna com escore de ansiedade igual a 21 afirmou "não senti necessidade" para justificar o comportamento de não buscar auxílio psicológico no GRAPAL (não apresentou justificativas para as outras questões); e um aluno com escore de ansiedade igual a 23 justificou seu comportamento de não buscar auxílio psicológico no GRAPAL alegando "não fui chamado" (também não apresentou justificativas para as demais questões).

\subsection{Resultados dos TATs}

Tanto os Inventários de Depressão e de Ansiedade de Beck como o formulário de Questões Complementares e o TCLE continham um espaço próprio a ser preenchido pelos alunos com seu endereço eletrônico (e-mail) a fím de serem contatados e 
convidados, posteriormente, para participar da segunda fase da pesquisa. Excluídos os protocolos cujos e-mails não existiam, os ilegíveis e os que não foram fornecidos, foram enviadas Cartas-Convites para 109 sujeitos para participarem do Teste de Apercepção Temática, assim distribuídos nos anos da graduação:

Tabela 24 - Sujeitos convidados para participar do TAT

\begin{tabular}{|c|c|c|c|c|c|c|c|c|c|}
\hline \multirow{2}{*}{ ANO } & \multirow{2}{*}{ GÊNERO } & \multicolumn{4}{|c|}{ BAI (escore) } & \multicolumn{4}{|c|}{ BDI (escore) } \\
\hline & & 0 & $1-10$ & $11-19$ & $\geq \mathbf{2 0}$ & $\mathbf{0}$ & $1-11$ & $12-19$ & $\geq \mathbf{2 0}$ \\
\hline \multirow[t]{2}{*}{1} & F & 0 & 5 & 5 & 1 & 0 & 5 & 3 & 1 \\
\hline & M & 0 & 3 & 3 & 1 & 0 & 4 & 1 & 2 \\
\hline \multirow[t]{2}{*}{2} & $\mathrm{~F}$ & 0 & 6 & 3 & 1 & 0 & 7 & 3 & 0 \\
\hline & M & 0 & 12 & 1 & 2 & 0 & 10 & 5 & 0 \\
\hline \multirow[t]{2}{*}{3} & $\mathrm{~F}$ & 1 & 4 & 4 & 2 & 0 & 8 & 0 & 3 \\
\hline & M & 0 & 6 & 1 & 0 & 0 & 7 & 0 & 0 \\
\hline \multirow[t]{2}{*}{4} & F & 1 & 2 & 2 & 0 & 1 & 2 & 2 & 0 \\
\hline & M & 1 & 12 & 0 & 1 & 0 & 12 & 2 & 0 \\
\hline \multirow[t]{2}{*}{5} & $\mathrm{~F}$ & 1 & 5 & 0 & 0 & 0 & 5 & 1 & 0 \\
\hline & M & 2 & 6 & 0 & 0 & 1 & 5 & 1 & 1 \\
\hline \multirow[t]{2}{*}{6} & F & 2 & 4 & 1 & 1 & 1 & 5 & 2 & 0 \\
\hline & M & 0 & 6 & 1 & 0 & 0 & 4 & 2 & 0 \\
\hline \multirow[t]{2}{*}{ TOTAL } & F & 5 & 26 & 15 & 5 & 2 & 32 & 11 & 4 \\
\hline & $\mathrm{M}$ & 3 & 45 & 6 & 4 & 1 & 42 & 11 & 3 \\
\hline
\end{tabular}

Foram realizados os testes estatísticos U de Mann-Whitney e Qui-quadrado, com os escores dos alunos aos quais foram encaminhadas as Cartas-Convites. Ao compararem-se os níveis de sintomas ansiosos com o gênero, foi identificada diferença significativa $(p=0,027)$, relacionada ao quinto ano, que não teve nenhum aluno com escore Leve ou Moderado convidado a participar do teste.

Das 109 cartas-convites encaminhadas, apenas 7 sujeitos manifestaram interesse em participar do TAT. Dos 7 sujeitos que aceitaram realizar o TAT, três eram do sexo feminino (dois do primeiro ano e um do segundo ano) e quatro do sexo masculino, um cursando o segundo ano e três cursando o quarto ano da graduação). 
Nenhum desses sete participantes apresentou escore positivo para depressão ou ansiedade, tendo todos sido incluídos na categoria de sujeitos da pesquisa por enquadrarse segundo o critério (ii) do item 3.1 supra, que define como sujeito da pesquisa aqueles que "não atingiram a nota de corte, não apresentando escores positivos para quadros depressivos/ansiosos, mas que sentem ou já sentiram, durante a graduação, algum tipo de dificuldade ou sofrimento emocional e psíquico, e não procuraram nenhum tipo de auxílio em saúde mental. Os escores para depressão e ansiedade desses sete sujeitos foram:

Tabela 25 - Escores, gênero e ano da graduação dos sujeitos que realizaram o TAT

\begin{tabular}{ccccc}
\hline Aluno & Ano da graduação & Gênero & Resultado do BAI & Resultado do BDI \\
\hline 1 & 1 & F & 16 & 17 \\
2 & 1 & F & 14 & 13 \\
3 & 2 & F & 08 & 09 \\
4 & 2 & M & 07 & 13 \\
5 & 4 & M & 02 & 04 \\
6 & 4 & M & 02 & 09 \\
7 & 4 & M & 04 & 06 \\
\hline
\end{tabular}

Os testes foram analisados e interpretados, e não estão presentes em sua forma integral por recomendação do CRP, a fim de preservar o sigilo dos conteúdos. Os aspectos psíquicos considerados mais importantes para os objetivos dessa pesquisa foram sintetizados e apresentados imediatamente após cada prancha para melhor compreensão, quais sejam: (i) quais sentimentos foram despertados, (ii) os tipos de ansiedades e defesas percebidos, (iii) os conflitos prevalentes, (iv) a integração do ego, e (v) a adequação do superego.

Da análise das interpretações dos TATs, observamos que todos os sujeitos do sexo feminino mencionaram, pelo menos, um sentimento em cada uma das 5 pranchas que lhes foram apresentadas. O mesmo não ocorreu com 3 sujeitos do sexo masculino. Apenas um aluno (6) mencionou sentimentos em todas as 5 pranchas. Os demais sujeitos (do gênero masculino) não mencionaram sentimentos em, pelo menos, uma das pranchas (o Aluno 4 omitiu sentimentos na prancha 8RM, o Aluno 5 omitiu sentimentos na prancha 7RH e o Aluno 7 omitiu sentimentos na prancha 9MF). 
Durante a aplicação do TAT, foram mencionados 108 sentimentos pelos 7 sujeitos. A grande maioria (84 ou 78,5\%) dos sentimentos mencionados estava associada a um estado de mente depressivo e/ou ansioso, como a tristeza (mencionada 8 vezes), o cansaço (citado 7 vezes), a preocupação (citada 8 vezes), a raiva (mencionada 6 vezes), além de sentimentos como o desânimo, angústia, insegurança, insatisfação e chateação, todos citados mais de duas vezes, e outros sentimentos similares ou de sentido aproximado de outros já mencionados.

Sentimentos percebidos como positivos ou otimistas apareceram 23 vezes, como gostar (10 vezes), calma (3 vezes), felicidade (2 vezes), satisfação (duas vezes), alívio, confiança, afeto, amor, otimismo, e "não derrotado", mencionados uma vez.

Somente dois sujeitos, ambos do sexo masculino (Alunos 5 e 6) não mencionaram nenhum dos sentimentos ditos positivos ou otimistas. Também mencionaram sentimentos com menos frequência o Aluno 5 (citou sentimentos por 4 vezes) e o Aluno 6 (por 9 vezes). $\mathrm{O}$ aluno que mencionou sentimentos com mais frequência foi o Aluno 7 (23 vezes), seguido pela Aluna 2 (22 vezes), pelas Alunas 1 e 3 (18 vezes) e pelo Aluno 4 (13 vezes).

Em relação às defesas que emergiram, houve um predomínio de defesas do tipo racionalização em 4 sujeitos, um do sexo feminino e 3 do sexo masculino (Alunos 2, 4, 6 e 7). Em um sujeito do sexo feminino (Aluna 1), predominou a defesa maníaca, e, em dois sujeitos (Aluna 3 e Aluno 5), não houve predomínio de um único tipo de defesa. Essas surgiram em tipos variados (racionalização, negação, dissociação, idealização regressão e defesa maníaca).

Considerando-se os tipos de ansiedades percebidas, todos os sujeitos apresentaram, em, pelo menos, uma prancha, ansiedade paranoide. Todos os sujeitos também revelaram, em, pelo menos, uma prancha, o conflito relativo à realização de tarefas, isto é, ter necessidade ou obrigação em realizar uma atividade e não querer ou não saber se é capaz de realizá-la.

Quanto à integração do ego, em média, prevaleceu uma integração egoica boa e razoável (das 35 pranchas apresentadas aos 7 sujeitos, 22 revelaram integração de ego consideradas "razoável" e "boa"). As outras 13 pranchas identificaram integração do ego "fraca"). Seis sujeitos (Alunos 1, 2, 3, 4, 5 e 6) apresentaram integração fraca do ego em, pelo menos, uma prancha, sendo as demais consideradas de integração razoável. Somente um sujeito (Aluno 7) não apresentou nenhuma prancha cuja interpretação indicava 
integração "fraca" de ego, prevalecendo, em seu TAT, uma integração egoica considerada "boa".

Em relação à adequação do superego, este foi pouco evidenciado na maioria das pranchas, só pôde ser percebido em 16 das 35 pranchas. Porém, quando identificado, o superego foi classificado como "rígido" em 8 pranchas, "atuante" em 5 pranchas e "flexível” em 3 pranchas.

Tabela 26 - Integração do ego

\begin{tabular}{cccccc}
\hline Aluno & Prancha 1 & Prancha 7RH & Prancha 8RM & Prancha 9MF & Prancha 12H \\
\hline 1 & Razoável & Razoável & Fraca & Fraca & Fraca \\
2 & Boa & Fraca & Razoável & Boa & Razoável \\
3 & Razoável & Razoável & Fraca & Fraca & Fraca \\
4 & Boa & Razoável & Fraca & Razoável & Razoável \\
5 & Razoável & Fraca & Razoável & Fraca & Fraca \\
6 & Razoável & Razoável & Fraca & Fraca & Razoável \\
7 & Razoável & Boa & Boa & Boa & Boa \\
\hline
\end{tabular}

Considerando que o superego só pode ser apreendido por meio do desfecho da história, a sua ausência implica a omissão por parte dos sujeitos que, embora tenham sido instruídos para criar um final para história, não o fizeram em todas as pranchas que lhes foram apresentadas, restando 21 histórias sem conclusão.

Apenas os Alunos 2 e 7 criaram desfecho em todas as pranchas que lhes foram apresentadas. O Aluno 1 não apresentou nenhum desfecho em nenhuma das 5 pranchas; os Alunos 3 e 6 criaram desenlaces em duas pranchas; e os Alunos 4 e 5 criaram desenlaces em apenas uma prancha. 
Tabela 27 - Adequação do superego

\begin{tabular}{cccccc}
\hline Aluno & Prancha 1 & Prancha 7RH & Prancha 8RM Prancha 9MF & Prancha 12H \\
\hline 1 & $\begin{array}{c}\text { Não } \\
\text { Evidente }\end{array}$ & Não Evidente & $\begin{array}{c}\text { Não } \\
\text { Evidente }\end{array}$ & $\begin{array}{c}\text { Não } \\
\text { Evidente }\end{array}$ & Não Evidente \\
2 & Rígido & Rígido & Rígido & Atuante & Rígido \\
3 & Rígido & Não Evidente & $\begin{array}{c}\text { Não } \\
\text { Evidente }\end{array}$ & Rígido & Não Evidente \\
4 & Não & Não Evidente & $\begin{array}{c}\text { Não } \\
\text { Evidente } \\
\text { Evidente }\end{array}$ & $\begin{array}{c}\text { Não } \\
\text { Evidente }\end{array}$ & Rígido \\
5 & Não & Rígido & $\begin{array}{c}\text { Não } \\
\text { Evidente }\end{array}$ & Evidente & Não Evidente \\
6 & Atuante & Não Evidente & $\begin{array}{c}\text { Não } \\
\text { Evidente }\end{array}$ & Atuante & Não Evidente \\
7 & Atuante & Flexível & Flexível & Atuante & Flexível \\
\hline
\end{tabular}




\section{DISCUSSÃO}

Considerando-se a associação entre os resultados obtidos, foi observada uma diminuição na frequência de sujeitos ansiosos em nível Leve e Moderado, e um aumento dessa frequência em Nível Mínimo, conforme os Ciclos mudavam do Básico ao Clínico e desse ao Internato, indicando uma tendência de redução dos escores de ansiedade conforme o avanço do curso. Esse resultado, considerado significante do ponto de vista estatístico, pode indicar que a intensidade de sintomas ansiosos talvez não esteja unicamente associada ao currículo médico, embora esse seja um fator importante, como já observado em outros importantes estudos acerca da saúde mental do estudante de Medicina (Baldassim, 2003; Millan et al., 2005; Smith et al., 2007).

Essa frequência menor de sujeitos com ansiedade mais severa nos últimos Ciclos também pode ter sido influenciada pelos escores apresentados pelos sujeitos do quinto ano, que se mostraram abaixo da média dos demais anos da graduação e reduziram os resultados apresentados pelo Internato, sendo que essa diferença foi considerada estatisticamente significativa $(p=0,001)$.

Os escores predominantemente baixos apresentados no BAI pelo quinto ano podem ter sofrido influência direta do contexto em que foi aplicado o teste, logo após a realização de uma atividade denominada OSCE, cuja tradução para o Português é "Avaliação Estruturada e Objetiva de Desempenho Clínico”. Embora seja uma avaliação, o OSCE não é uma prova, não gera nenhuma alteração nas notas dos alunos nem em sua aprovação no final do ano letivo. É considerado um momento em que o aluno tem a oportunidade de avaliar seu conhecimento, e que o habilita a perceber e corrigir eventual falha ou déficit em relação aos conteúdos aprendidos. Por isso, é mais considerada uma atividade de treinamento, que permite ao aluno simular a realização da prova de residência, o que, eventualmente, pode ajudá-lo a controlar a própria ansiedade.

Assim, é possível que, após a realização dessa atividade, os alunos estivessem se sentindo empolgados e aliviados em relação à atividade do OSCE, o que poderia influenciar os resultados dos inventários, reduzindo seus escores.

Por outro lado, a maior frequência de sujeitos ansiosos no Ciclo Básico pode ser explicada em função de fatores ansiogênicos com os quais o estudante se depara no início 
do curso, como os processos de adaptação e socialização dos alunos iniciantes ao novo ambiente acadêmico em que foram inseridos.

O processo de socialização, adaptação e inserção do aluno em um novo grupo consiste num movimento de expansão e extroversão, contrário ao que vinha sendo por ele realizado, quando se dedicava quase que exclusivamente aos estudos para o vestibular.

Antes de ingressar na faculdade, especialmente na Universidade de São Paulo, cuja nota de corte para aprovação no vestibular é alta, o sujeito se vê, de certa maneira, obrigado a permanecer por um período, em média de dois anos, imerso nos estudos, privando-se, muitas vezes, de uma vida social satisfatória, o que implica num movimento de introversão e isolamento em algum grau.

Uma vez atingida a meta de ingressar na faculdade, o sujeito tem que realizar um movimento inverso, de expansão e extroversão, para se adaptar a outro ambiente inteiramente novo e estranho, e de se abrir para um novo grupo, para uma nova rotina, e estabelecer novos vínculos com pessoas e professores desconhecidos.

Normalmente, essa é uma atividade desejada por esses sujeitos, mas nem por isso não ansiogênica, especialmente para quem, na maioria das vezes, ainda está vivenciando a adolescência. Essa transição, já ressaltada anteriormente, está relacionada à tendência de agrupamento e à complexa construção da identidade.

É sabido que essas mudanças de etapas no desenvolvimento humano não ocorrem de forma pontual, mas, por meio de um processo que se prolonga no tempo, marcado por avanços e retrocessos, até sua estabilização. Aliás, a experiência em relação à mudança e ao novo não é, de modo geral, considerada uma tarefa simples e fácil, especialmente para aqueles sujeitos que possuem traços obsessivos, como é característico no estudante de Medicina (Millan, 2005).

Assim, o ingresso na faculdade é marcado por inúmeras mudanças e novas tarefas que o jovem deve cumprir e que poderiam explicar a maior frequência de sujeitos ansiosos. Ele precisa conscientizar-se que, nesse momento, está sendo inserido num universo desconhecido, mais amplo, diversificado e complexo do que aquele a que estava habituado. Assim, tem que realizar diversas adaptações, como aos novos métodos de ensino e estudo, às notas, que não são mais tão excepcionais e altas como estavam habituados, à nova cidade (para quem não é natural deste município), transporte e moradia (para aqueles que vieram de outras localidades), a novos amigos, professores e formas de se relacionar, à nova rotina, a novos horários e à nova alimentação (Millan et al., 1999). 
É comum que os grupos que se formam nesse momento permaneçam os mesmos até o final do curso, sendo que não é difícil que aqueles que apresentam dificuldade nesse agrupamento inicial permaneçam deslocados e isolados até a conclusão do curso. Esse fenômeno pode preocupar e disparar ou aumentar a ansiedade, principalmente naqueles estudantes mais tímidos.

Esses agrupamentos ocorrem, predominantemente, por identificações que os sujeitos fazem uns com os outros. Porém, para que um sujeito se identifique com outro, é preciso contar com uma base de personalidade previamente desenvolvida (na primeira infância) em grau suficiente para que os relacionamentos e os vínculos possam ser estabelecidos (relações objetais).

Contudo, essa base da personalidade do indivíduo nem sempre teve uma boa constituição inicial, e as questões a ela inerentes, que estavam, de certa forma, adormecidas e encobertas pela meta de ingressar na faculdade, muitas vezes, ressurgem no início do curso, podendo se manifestar por meio de sintomas ansiosos e/ou depressivos.

Conforme o sujeito vai se adaptando ao novo ambiente, se inserindo num grupo, e estabelecendo relacionamentos e vínculos importantes, passa a sentir-se acolhido, apoiado e mais seguro, o que tenderia a reduzir esses sintomas (Hefner, Eisemberg, 2009).

Há, ainda, a questão já apontada por Millan e cols., denominada de "fase do desencanto", na qual se observa a desilusão e frustração sofrida pelos alunos do Ciclo Básico, que sucede a "fase da euforia" pós-aprovação no vestibular e ingresso na faculdade (Millan et al., 1999). De acordo com esses autores, o aluno desse estágio sofre uma desilusão relacionada à "didática, à longa duração das aulas, ao excessivo volume de estudo...”. Ademais, há, ainda, a decepção sofrida com as notas das provas abaixo das expectativas, uma vez que esses alunos eram reconhecidos como os melhores da classe. "A perda desse status, pode provocar em alguns casos, sentimentos de desvalia e desejo de abandonar o curso, e em outros, uma verdadeira crise de identidade... Somando-se a isso, no final de cada um dos cursos aparece a angústia de nada ter aprendido, ou ainda de ter esquecido toda a matéria estudada" (Millan et al., 1999).

Em relação aos níveis de sintomas ansiosos (Tabela 2), observou-se que, entre os Ciclos Básico e Internato, a frequência de sujeitos ansiosos aumentou 18,2\% em nível Mínimo e diminuiu 15,6\% em nível Leve. Já em relação aos sintomas em nível Moderado, 
a variação observada entre esses Ciclos foi de 2,6\% (para menor), sendo essa variação estatisticamente significativa $(p=0,001)$.

Essa flutuação menor (de 2,6\%) de sujeitos com sintomas em nível moderado pode sugerir uma constância de sintomas ansiosos (traços) e não apenas de estados ansiosos reativos ou responsivos ao ambiente, apesar da limitação imposta pela transversalidade desta pesquisa, o que somente poderia ser contornado por meio de estudos longitudinais que pudessem acompanhar os mesmos sujeitos ao longo de sua formação.

Assim, esse resultado, que aponta para uma redução de apenas 2,6\% na frequência de sujeitos com transtorno de ansiedade entre o início e a fase final do curso, pode sinalizar a existência de um número de sujeitos ansiosos que se mantém quase constante, talvez por falta de intervenções ou de acesso a tratamentos especializados.

$\mathrm{Na}$ análise dos resultados considerados em relação ao ano da graduação, observouse que o terceiro ano foi o que apresentou a maior frequência de sujeitos ansiosos e deprimidos em relação aos demais. Embora tenha sido o ano da graduação com o menor $\mathrm{N}$ (apenas 50 indivíduos) e esse número representar uma limitação à pesquisa, esse resultado pode estar relacionado às preocupações com os agrupamentos em "panelas" (grupos de trabalho durante o internato), ao medo de ficar no "lixão", ao ressentimento em razão da dependência financeira familiar, e à competição por melhores notas (Millan, 2005).

É também o momento em que, passada a "fase de euforia", alguns alunos experimentam a "fase da desilusão" (Millan et al., 1999) de forma mais intensa, possivelmente por terem mais dificuldade de lidar com a desilusão e o luto decorrente. Há, ainda, as questões relativas aos relacionamentos entre colegas, como as dificuldades em lidar com os conflitos, mudanças de grupos, isolamento e estigmas que nesse momento, passado algum tempo de convívio, já estão formados. 
Os resultados dos testes de depressão, ao contrário, não revelaram nenhuma tendência de aumento ou redução da frequência de sujeitos deprimidos ao longo do curso. Mas a variação da frequência de sujeitos com depressão nos Níveis Mínimo, Leve e Moderado, de 10,1\%, 8,3\% e 1,6\%, respectivamente, quando agrupados segundo os Ciclos da graduação, repete o encontrado por meio dos inventários de ansiedade, nos quais a menor flutuação da frequência de sujeitos também foi encontrada entre os que apresentaram sintomas mais severos, em nível moderado.

Reconsiderando-se a ressalva anteriormente realizada à limitação imposta pelo método transversal adotado nesse estudo, esses resultados podem indicar que uma parcela de sujeitos permanece deprimida do início ao final do curso, o que poderia ser indicador de que esses sujeitos afetados mais intensamente pela depressão e pela ansiedade permanecem sem tratamentos adequados durante todo o período da graduação.

De maneira geral, como demonstrado em outras pesquisas anteriormente citadas, $o$ rigor curricular e a crescente complexidade do curso, que aumenta com o seu avanço, é um importante fator associado à ansiedade e à depressão. Porém, parece não ser o único, uma vez que, no presente estudo, o ciclo básico apresentou a maior frequência de sujeitos ansiosos, o que aponta a presença de outros fatores associados à doença, como as questões ligadas à socialização, adaptação a um meio estranho e a formação da identidade do aluno.

Em relação ao gênero, os resultados do BDI parece confirmar outro estudo (Millan, 2005) que mostrou que, entre estudantes de Medicina, não há prevalência do gênero em relação aos níveis de sintomas depressivos.

\subsection{Questionário}

A análise dos resultados do Questionário, que buscou investigar a demanda e o acesso dos sujeitos em relação ao auxílio psicológico, revelou que a metade da população estudada (218 ou 50,3\%) que respondeu afirmativamente a, pelo menos, uma das três primeiras questões foi considerada com demanda ou algum tipo de necessidade ou interesse em receber auxílio psicológico.

Considerando-se esses 218 sujeitos, observou-se que a frequência de sujeitos com essa demanda aumentava conforme o avanço do curso, sendo que o Internato apresentou a maior frequência de sujeitos (com demanda por auxílio psicológico). Apesar dos 
sujeitos do Internato estarem mais tempo na graduação e esse resultado ter um registro histórico (desde o início do curso), essa variação mostrou-se significativa do ponto de vista estatístico $(p=0,001)$.

Não obstante o caráter histórico e cumulativo da percepção dessa necessidade, não se podem ignorar outras importantes razões que justificam essa tendência de aumento da demanda por auxílio psicológico ao longo do curso, como o aumento das exigências acadêmicas e curriculares que crescem em complexidade e quantidade de conteúdo, o regime de dedicação integral, a preocupação com a prova da residência e escolha da especialidade, e as tensões inerentes aos atendimentos a pacientes (Millan et al., 1999).

Nos três primeiros anos, período em que os alunos dispõem de mais tempo livre que nos demais anos do curso, é comum constatar que esses se envolvem em mais atividades extracurriculares ou eletivas do que são realmente capazes de realizar. Muitas vezes, acumulam participações em várias Ligas, em atividades relacionadas ao Centro Acadêmico, ao Departamento Científico, em Iniciações Científicas, Congressos universitários, Bandeira Científica, Med-Alegria, Med-Ensina, Med Jr. e outras extensões ou dedicam-se intensamente aos treinos e às competições oferecidos pela Atlética.

Esse excesso de atividades, muitas vezes, ocorre em função de alguns fatores objetivos, como o grande interesse pelas atividades oferecidas pela faculdade, pela curiosidade em aprender o máximo possível, pelo desejo de participar da vida universitária ou incrementar o currículo a fim de adquirir um diferencial na prova da residência. Porém, outras vezes, ocorrem por fatores inconscientes, como a voracidade, a competitividade, a onipotência, e fatores relacionados à valorização da autoimagem e à construção da identidade.

Assim, muitas vezes, os estudantes permanecem por um determinado período realizando atividades em excesso, sem se darem conta do quanto pode este comportamento lhes despertar ansiedade. Não é incomum sofrerem ao se depararem com a difícil percepção de que precisam abrir mão de alguma atividade eletiva. 
É certo que os indivíduos são diferentes entre si, e que, em função disso, também apresentem habilidades e necessidades de descanso e sono diversas, o que acaba resultando num aumento do estresse para aqueles que possuem maior necessidade de sono ou tempo na realização das tarefas a que se propuseram realizar.

Mas essas diferenças individuais, quando ignoradas pelos estudantes que se comparam uns com os outros, atribuem para aqueles que realizam poucas atividades eletivas ou acabam desistindo de alguma(s) dela(s), um caráter pejorativo, associado, muitas vezes, à incapacidade ou incompetência, que depõe contra a imagem (ideal) do estudante perante o grupo.

Além do excesso de atividades nessa fase, os sintomas ansiosos e depressivos também podem ser agravados ou disparados em função da forma como os alunos se relacionam com a execução dessas inúmeras tarefas a que se propõe realizar. A grande maioria dos alunos que se insere em alguma dessas atividades o faz com grande envolvimento pessoal, se empenhando em realizá-las com elevado grau de exigência e

performance. É comum que alunos que participam de alguma modalidade esportiva na Atlética, por exemplo, deixem de assistir a aulas e estudar as matérias curriculares para dedicarem o máximo de tempo possível aos treinos.

Aqueles que querem apenas praticar uma atividade física, seja pelo gosto de praticar um esporte, seja para ter uma vida menos sedentária e mais saudável, acabam procurando academias particulares e outros centros esportivos diferentes da Atlética. A competitividade, embora tenha aspectos positivos, como apontado em outro estudo (Millan et al., 1999), traz consigo, em alguns casos, um custo emocional nem sempre consciente e percebido pelo aluno.

Assim, a forma como alguns alunos se relacionam com essas atividades pode, por vezes, se tornar uma fonte de preocupação e angústia, em razão da quantidade de tarefas assumidas, da intensidade do envolvimento com essas tarefas e do nível de exigência, muitas vezes, irreal e idealizado em relação aos resultados esperados.

Esse perfeccionismo e a idealização dos resultados foram observados no TAT, como mostra o trecho apresentado pelo Aluno 2 na Prancha 1 (O menino e o violino): “...Ele tá meio frustrado porque não consegue tocar do jeito que queria. Ele tá tentando melhorar mas está cansado. Ele olha preocupado para o violino porque sabe que tem que praticar para se apresentar bem." (sic). 
Parece que este tipo de comportamento competitivo acaba por criar um modelo idealizado de "self" com o qual os alunos se identificam em função de características comuns de suas personalidades, como o perfeccionismo, a competitividade e os traços obsessivos; e, quando compartilhado pelo grupo estudantil, define modelos de "como ser um aluno FMUSP”. Pode ser que esses modelos idealizados passem a ser perseguidos por muitos alunos, sob pena de serem discriminados e não aceitos pelo grupo ou dele serem segregados, tornando-se um "shibboleth" médico.

Essa dinâmica lembra o mito grego conhecido como "Cama de Procusto" ou "Leito de Procusto". De acordo com esse mito, havia um bandido, gigante, chamado Procusto ou "Esticador", que possuía uma cama de ferro que tinha exatamente o seu tamanho. Ele fazia com que suas vítimas deitassem em sua cama, e, se fossem maiores que ela, Procusto cortava-lhes a parte do corpo que ficava para fora, amputando-lhes a parte dos membros que excedia o tamanho da cama; e, se fossem menores que a cama, ele as esticava até que atingissem o seu tamanho exato. Um dia, a deusa Atena, ouvindo o clamor das vítimas de Procusto, foi ao seu encontro para convencê-lo a parar com essa conduta. Porém, o gigante argumentou que estava apenas fazendo justiça, acabando com as diferenças entre as pessoas. Atena calou-se, e seu silêncio fez com que aumentasse ainda mais a crueldade de Procusto. Foi, então, que o herói Teseu surgiu e fez com que Procusto se deitasse em sua cama, mas na posição transversal, ficando com a cabeça e pés para fora dessa. Teseu cortou as partes que excediam a cama e, assim, matou o bandido.

Esse mito trata da intolerância em relação àqueles que são diferentes de um determinado modelo ou padrão, tema que, aliás, é extremamente atual. A intolerância às diferenças ou aos desiguais parece ser uma característica do ser humano, que impõe a estes um grande sofrimento, uma mutilação física ou psicológica. É, portanto, um fator capaz de produzir ou intensificar tanto a ansiedade como a depressão, pois origina, naqueles que não se encaixam nos modelos ou padrões estabelecidos, o medo da discriminação e da violência (inclusive a psíquica), bem como incita o aparecimento de mecanismos de defesa necessários para combatê-lo.

Ademais, também seria possível adotar esse modelo para as questões intrapsíquicas, de forma que a intolerância com um "jeito de ser" pode existir dentro do próprio sujeito. Assim, o indivíduo que percebe ser diferente do seu ideal de ego, isto é, se percebe diferente daquela pessoa que gostaria de ser, pode entrar em conflito consigo mesmo, não se aceitando como indivíduo, com suas características e possíveis limitações. Por meio 
do mecanismo da projeção, esse comportamento de não tolerar aspectos inaceitáveis de seu próprio self, passa a ser projetado no ambiente, tal qual fez Procusto, que, aparentemente, não aceitava seu gigantismo.

Assim, a identidade dos sujeitos, em processo de formação de identidade (por meio dos processos psíquicos de projeção/introjeção de conteúdos internos inconscientes), pode facilitar a criação de um ambiente com características de extrema exigência, persecutório, e muito competitivo, e, portanto, favorável ao aumento da ansiedade e depressão. Desta forma, os aspectos inconscientes projetados no ambiente afetam o clima institucional e este, os indivíduos nele inseridos; aparentemente, cria-se, então, um círculo ou sistema fechado que se retroalimenta. Dentre esses conteúdos inaceitáveis, que destoam da forma como o sujeito gostaria de ser, pode estar o reconhecimento da própria fragilidade e doença, materializada na busca por auxílio psicológico e/ou no próprio tratamento.

Uma possível explicação para o aumento da demanda por auxílio psicológico entre o Ciclo Básico e o Clínico pode ocorrer em função do aumento da autopercepção de si mesmo e da existência de um mundo interno e subjetivo, povoado com questões pessoais, das quais os alunos passam a se dar conta em função do desenvolvimento pessoal e da maturidade que vão adquirindo ao longo do curso. Além disso, já estar inserido e amparado por um grupo, que, neste momento do curso, deveria ser uma questão superada, pode dar segurança e confiança ao aluno, e facilitar o reconhecimento de suas dificuldades pessoais, fragilidades, e, com isso, facilitar o acesso ao auxílio psicológico.

Ademais, é curioso o fato de o Ciclo Básico apresentar a maior frequência de sujeitos com ansiedade e a menor de sujeitos com demanda por auxílio psicológico. Isso poderia ser explicado por um déficit na autopercepção de necessidade de ajuda psicológica, desconhecimento sobre o próprio sofrimento, e das formas e possibilidades de lidar com eles, característicos da imaturidade do jovem estudante. Mas também pode ocorrer pelo receio de mostrar-se frágil ou de ser visto com desconfiança num momento em que se pretende parecer interessante, e cheio de virtudes e qualidades para ser aceito, querido e incluído em um grupo. Nesse momento, reconhecer a necessidade de ajuda psicológica pode parecer prejudicial à sua imagem e à sua socialização.

Além disso, devem ser consideradas as defesas maníacas, tais como a negação, o controle onipotente e a dissociação, tão presentes nos calouros, que se encontram na "fase 
de euforia" (Millan et al., 1999), e que dificultam a percepção e aceitação de dificuldades emocionais ou psíquicas.

O Internato, ao contrário, foi o Ciclo que apresentou maior demanda por auxílio psicológico. Esse dado pode indicar que a maioria dos internos reconhece a necessidade de apoio psicológico, ou por sentir que poderia se beneficiar desse tipo de serviço, mesmo não apresentando sintomas ansiosos ou depressivos, como também por sentir que o momento do internato representa um período da vida acadêmica que, pelas experiências complexas que impõe, traz consigo a exigência de lidar com questões novas, inesperadas, intensas, e, por isso, potencialmente ansiogênicas e depressivas ou por se perceberem ansiosos e deprimidos.

Esse dado pode decorrer do fato do interno ter de se submeter a um aumento da quantidade de plantões, redução do tempo de repouso, do sono, do lazer e dos estudos, a níveis considerados capazes de prejudicar sua condição emocional e seu desempenho em atividades (Millan et al., 1999).

Mais uma vez, não se pode deixar de considerar que é subjetiva a forma como cada sujeito lida com as demandas (inclusive as do sexto ano), mas sentimentos ambíguos em relação a esse período da graduação são comuns. Podem, por um lado, apresentar grande empolgação e autorrealização com o fim da graduação e com as atividades diretamente ligadas ao exercício e à aprendizagem da Medicina. Por outro lado, também podem desenvolver preocupações em relação aos atendimentos aos doentes, com a escolha da especialidade, a concorrência por uma vaga na residência médica, a separação dos colegas, e a mudança do lugar (papel) de estudante de Medicina para o lugar de médico e as responsabilidades a ele inerentes.

Incluem-se, aqui, todas as angústias relacionadas ao exercício profissional, como não contar mais com a proteção e assistência de professores, ter de responsabilizar-se pela conduta escolhida ou pelos erros que temem cometer, bem como, com a entrada no mercado de trabalho e no mundo adulto.

Em “Alguns aspectos da formação médica”, os autores apontam que os 3 aspectos (atendimento ao paciente, dedicação integral e a escolha de especialidade) podem provocar nos internos a sensação de estarem diante de obstáculos intransponíveis, o que podem lhes acarretar desânimo, depressão e vivência de impotência, motivos suficientes para buscar apoio psicológico (Millan et al., 1999). 
Contudo, embora os internos tenham apresentado maior demanda por auxílio psicológico do que os demais alunos, eles não acessaram mais esses serviços que os outros. Isso pode ter ocorrido em razão da resistência, manifestada por meio do receio de a doença psíquica, e de tudo que a ela se relacione (auxílio psicológico, tratamento psicológico ou medicamentoso), possam repercutir negativamente no seu desempenho profissional, em fase inicial.

A dificuldade do interno em buscar ajuda psicológica pode também estar associada à identidade médica que veio se constituindo ao longo do curso e que, em razão das características que apresenta, o coloca, algumas vezes, em “dificuldade em aceitar o papel de pacientes" (Alves H., Nogueira Martins, e col., 2005).

Há, ainda, a questão do preconceito e do estigma que gira em torno das doenças psíquicas, especialmente em relação à depressão. Esta, como aponta Meleiro, é, comumente, considerada pelo médico como uma fraqueza de caráter, que pode ser vencida pelo esforço e pela vontade de se ajudar ou melhorar (Meleiro, 1999).

$\mathrm{Na}$ associação dos resultados que consideraram a intensidade de sintomas ansiosos e depressivos com a presença de demanda por auxílio psicológico, percebeu-se que, de uma forma geral, os sujeitos possuíam boa percepção de seu estado mental, uma vez que aqueles que apresentaram sintomas ansiosos e depressivos em níveis mais elevados (Leves e Moderados) também foram os que apresentaram maior demanda por auxílio psicológico (reconhecimento da necessidade de auxílio psicológico).

Porém, apesar de observada essa tendência de que os sujeitos com depressão e ansiedade mais intensa apresentem mais demanda por auxílio psicológico, a presença desses sintomas em maior intensidade não pode ser considerada como o fator determinante ou diretamente relacionado à demanda por auxílio psicológico. Isso porque os resultados dessa associação revelaram que os sujeitos com sintomas Leves (de intensidade média) apresentaram demanda maior por esse tipo de auxílio do que os sujeitos com sintomas Moderados e mais severos, sendo essa diferença considerada estatisticamente significativa ( $p=0,001$ para ansiedade, e $p=0,003$ para depressão). 
Isso pode ocorrer como decorrência da gravidade da própria doença, que reduz a esperança de uma melhora e a crença na existência de um tratamento eficaz, contribuindo ao entendimento popular que prega que "quem mais precisa é quem menos procura ajuda".

Outra explicação para o fato de que os sujeitos com sintomas Leves apresentaram mais demanda por auxílio psicológico do que os com sintomas em nível Moderado é a adaptação desses últimos ao sofrimento e aos sintomas, que implica na percepção de que a ansiedade ou a depressão são estados normais e inerentes à formação médica. Esse processo de "normalização" da doença e/ou do sintoma foi abordado em outro estudo (Czyz et al., 2013).

A normalização da doença e os correspondentes sintomas podem ser entendidos como uma forma de negação, já que o sofrimento e a dor psíquica passam a ser percebidos como naturais. Esse fenômeno pode ser observado por meio das respostas dadas ao questionário pelos alunos com escores positivos $(\geq 20)$ para depressão e/ou ansiedade, e que afirmaram não ter necessidade de buscar auxílio psicológico.

Estariam esses sujeitos sob influência de mecanismos de defesa que os impedem de reconhecerem-se doentes e precisando de ajuda, ou que, embora se percebam doentes, alegam não ter tempo para se tratar. Talvez, aqui, entrem em jogo defesas psíquicas, que impedem o reconhecimento do próprio sofrimento mental ou do funcionamento psíquico prejudicado, como a negação da necessidade de buscar auxílio ("não precisei" ou "não tive interesse"), ou a racionalização que invoca a falta de tempo para os tratamentos ("não tive tempo" ou, ainda, "achei que ia melhorar sozinho").

Assim, dos 24 sujeitos que apresentaram resultados de ansiedade em nível Moderado, 14 tinham percepção da necessidade de receber auxílio psicológico, mas somente 3 buscaram esse auxílio. O mesmo ocorreu com os 18 alunos que apresentaram escores Moderados de depressão, dos quais 11 tinham percepção da necessidade de buscar algum auxílio psicológico (demanda) e somente 4, efetivamente, acessaram esse serviço.

Portanto, 10 sujeitos com ansiedade e 7 com depressão em Nível Moderado não manifestaram qualquer necessidade de buscar auxílio psicológico, o que pode ser resultado de defesas psíquicas que negam e impedem a autopercepção de aspectos psicológicos e emocionais inadmissíveis à consciência (resistência).

$\mathrm{Na}$ associação dos resultados entre sujeitos com ansiedade e depressão e a demanda por auxilio psicológico, embora os testes estatísticos não tenham revelado uma diferença 
significativa, foi percebido que os sujeitos com depressão buscaram mais os serviços de saúde mental do que os que apresentaram ansiedade em igual nível, conduzindo à ideia de que a depressão é mais perceptível ou menos tolerada do que a ansiedade.

A ansiedade é, muitas vezes, considerada uma característica de personalidade, ao contrário da depressão, sempre concebida como uma doença.

Ademais, a depressão causa prejuízos mais evidentes na vida acadêmica, pessoal e profissional do que a ansiedade; como a dificuldade de concentração e redução na capacidade de armazenamento de informações, e consequente redução do desempenho escolar, além da redução do sono reparador, do desejo sexual, do embotamento afetivo, da dificuldade nos relacionamentos, da redução da tolerância à frustração do dia a dia, da perda de apetite, do choro fácil, dentre outros sintomas.

Além disso, a ansiedade parece ser considerada natural e, em certa medida, esperada no meio acadêmico, de forma que passa a ser mais tolerada e, até mesmo, confundida com pró-atividade, raciocínio rápido ou acelerado e prontidão em relação às demandas. Muitas vezes, pode se tornar difícil determinar o limite entre a ansiedade tolerável e a intolerável, entre a normal e a patológica, entre o sofrimento psíquico necessário e o desnecessário, entre o receio que ajuda a melhorar a performance acadêmica incrementando a dedicação aos estudos, e a que prejudica e reduz a capacidade de pensamento e raciocínio do sujeito.

\subsection{Acesso aos serviços de saúde mental}

Embora metade da população estudada (218 ou 50,2\%) tenha reconhecido a necessidade ou demanda por auxílio psicológico, apenas 72 (ou 16,6\%) dos sujeitos da pesquisa afirmaram já terem tido acesso a algum tipo de tratamento nessa área, o que inclui os que já concluíram, os que estavam realizando, e os que iniciaram e abandonaram algum tipo de tratamento. 
Dentre eles, 42 sujeitos afirmaram que estavam realizando algum tipo de tratamento psicológico na ocasião. Esses eram, predominantemente, do gênero feminino, embora essa diferença entre os gêneros não tenha sido considerada significativa do ponto de vista estatístico.

A diferença na proporção entre homens e mulheres, e níveis de seus sintomas em relação à busca por auxílio psicológico, revelou que as mulheres buscavam esse serviço independentemente do nível de sintoma, enquanto que os homens apresentavam uma relação direta entre aumento da intensidade dos sintomas e a procura por auxílio.

Esse resultado confirma o observado em outras pesquisas que apontaram que estudantes do sexo feminino acessam mais os serviços em saúde mental do que os do sexo masculino (Millan, 2005).

Por meio da quarta e última pergunta constante do Questionário, procurou-se investigar a proporção de alunos que já receberam alguma indicação ou sugestão de outrem para buscar auxílio psicológico. Com essa questão, pretendeu-se investigar se o estudante tinha autopercepção de seu estado psicológico, especialmente da necessidade de receber tratamento profissional em saúde mental. "Outrem", ou os "terceiros" aqui referidos, poderiam ser quaisquer pessoas do círculo social dos sujeitos, como parentes, amigos, colegas, namorados, professores ou outros.

Foram consideradas válidas 429 respostas a essa pergunta, sendo que $66(15,4 \%)$ sujeitos afirmaram já tê-la recebido. Em relação ao gênero, não houve diferença significativa do ponto de vista estatístico no recebimento dessa sugestão.

Os resultados revelaram que a maior parte dos sujeitos com depressão ou transtorno de ansiedade não recebeu nenhuma recomendação para buscar auxílio psicológico. Isso quer dizer que, dentre os 24 sujeitos com transtorno de ansiedade, 20 não receberam a sugestão dada por terceiros para que procurassem ajuda profissional. O mesmo ocorreu com 15 dos 18 sujeitos com depressão em Nível Moderado.

Esse resultado pode indicar que os sintomas dessas doenças nem sempre são percebidos pelas pessoas que convivem com os sujeitos por elas acometidos. Isso pode ocorrer por falha na percepção ou observação desses terceiros, que, por algum motivo, não atentam às mudanças comportamentais e sintomáticas e/ou pela falta de informação sobre essas doenças. Mas também pode ocorrer que esses sujeitos ansiosos e/ou depressivos escondam ou disfarcem os sintomas, encenando uma pseudossaúde mental ou "normalidade" comportamental. 
Essa ausência de sinais parece ser a mais grave das alternativas por surpreender o grupo social do sujeito deprimido quando este realiza uma tentativa ou efetiva o suicídio, causando grande perplexidade em seu meio. Esses sinais são, por vezes, percebidos $a$ posteriori, que, em caso de suicídio, já nenhuma providência pode ser tomada. Em alguns casos, surge a cruel dúvida se esses sinais foram percebidos e ignorados em virtude de algum mecanismo de defesa ou se realmente não era possível percebê-los na ocasião.

Outra possibilidade decorre da dificuldade enfrentada por esses parentes, amigos ou colegas em fazer algum tipo de intervenção ou sugestão. Recomendar ou sugerir que alguém precisa buscar auxílio psicológico de um profissional é, muitas vezes, uma comunicação que constrange ambos, o interlocutor e o sujeito que recebe a comunicação, sendo, muitas vezes, mal recebida pelo sujeito enfermo. Ele, na maioria das vezes, se não percebeu por si mesmo essa necessidade, poderá já estar sob influência da resistência e de defesas psíquicas criadas para combater essa percepção. Isso pode fazer com que qualquer sugestão nesse sentido seja percebida pelo sujeito como uma ofensa ou crítica, o que pode ocasionar o afastamento ou, até mesmo, o rompimento das relações entre o sujeito e aquele que sugeriu o tratamento psicológico.

Contudo, a omissão sempre será a pior solução, uma vez que o sujeito deprimido, sem tratamento ou perspectiva, permanecerá sob o risco de cometer o suicídio.

\subsection{Justificativas apresentadas ao comportamento de não buscar auxílio psicológico}

A justificativa mais alegada pelos alunos em relação ao comportamento de não buscar auxílio psicológico foi a de não sentir necessidade, o que pode ser um dado não questionável. Porém, quando alegada por sujeitos que apresentaram escores do BAI e/ou BDI em nível Leve e/ou Moderado, é possível inferir-se que havia uma real necessidade de auxílio psicológico e que este foi evitado.

Isso pode ocorrer por um déficit na percepção do próprio estado mental e baixa capacidade de insight, ou por decisão própria pautada em mecanismos de defesa que permitem ao sujeito, mesmo percebendo alguns sintomas ou que seu estado psíquico está de alguma maneira alterado ou prejudicado, achar desnecessário o auxílio psicológico. 
A negação da necessidade de auxílio psicológico por aqueles sujeitos que apresentam a doença depressiva ou ansiosa, de acordo com a teoria Kleiniana, constitui uma defesa maníaca (Klein, 1934).

Na defesa maníaca, o ego busca escapar do sofrimento causado pela culpa em relação à perda ou danificação do objeto amado, não só por meio da negação da realidade psíquica, mas também pelo controle onipotente do objeto, pela depreciação do objeto e pelo triunfo sobre esse e, ainda, por meio de outras defesas mais elaboradas, como a inibição da agressividade e a reparação do objeto (La Planche e Pontalis, 2000).

Assim, esses sujeitos estariam negando sua realidade psíquica interna de forma onipotente, bem como, seu sofrimento psíquico e seus sintomas, como se mal nenhum os pudesse abater.

A negação da própria doença (ansiosa ou depressiva) como uma forma de resistência se constitui em função de um conflito de ideias incapaz de ser solucionado pelo ego. Este, ou seu ideal (Ideal de Ego), não pode reconhecer a presença de certos aspectos psíquicos por serem considerados inadmissíveis e moralmente indesejáveis. A doença psíquica, bem como tudo o que se associa a ela, como o tratamento, precisa ser negada por representar esses aspectos inconcebíveis ao ego (ou ao ideal de ego).

Uma vez negada, ela é suprimida da consciência. Dessa forma, o tratamento ou auxílio psicológico passa a ser desnecessário, pois o sujeito não mais possui sofrimento ou sintomas a serem tratados.

Mas, por que a doença psíquica, como a depressão e/ou a ansiedade, não podem ser reconhecidas pelo ego (ou Ideal de Ego) e precisam ser negadas? A depressão e/ou ansiedade são consideradas doenças mentais associadas não só à fraqueza de caráter (Meleiro, 1999) mas também ao reconhecimento de que o sujeito não está "dando conta" de uma realidade, isto é, que nem sempre ele consegue lidar com todas as vicissitudes da vida sem se abalar, revelando, talvez, sua vulnerabilidade diante de certas situações difíceis de serem vividas e elaboradas (especialmente aquelas relacionadas com a perda e o luto).

Assim, um sujeito que pretende possuir apenas qualidades e virtudes, características idealizadas (Ideal de Ego), não pode conceber em si mesmo fragilidades, falhas, fracassos ou qualquer outra aspecto que possa se contrapor ou comprometer essas idealizações (onipotência e invulnerabilidade). 
No capítulo Estresse e o estudante de Medicina, Santos Guimarães afirma: "Problemas emocionais, desmoralização, relações interpessoais problemáticas, ansiedade e sintomas depressivos estão comumente presentes em médicos e estudantes de Medicina. Alguns dos mais valorizados traços de personalidade, por exemplo, como o perfeccionismo (que os estudantes levam para a sua prática), também os tornam mais vulneráveis ao estresse, à ansiedade e à depressão“ (Guimarães, 2008).

Não havendo outra saída, esse conflito (que ocorre num plano inconsciente) deve ser reprimido. Contudo, nem sempre a repressão é vitoriosa. Quando esta falha, reaparecem as angústias que, não podendo ser simbolizadas por meio de palavras, nem pensadas, acabam por formar determinados sintomas, como se vê, por exemplo, por meio do episódios de pânico, fobias e outros sintomas. "Se a repressão não é bem-sucedida, o resultado é a formação de sintomas" (Klein, 1923). Esses, então, passam a ser os representantes simbólicos do conflito insolúvel e das angústias inerentes.

Assim, alguns sintomas não podem ser reconhecidos pelo sujeito, pois, sendo representantes do conflito, enfraquecem toda a cadeia associativa de ideias (inconscientes) construída para evitar o sofrimento psíquico e, muitas vezes, passam a ser egossintônicos, mecanismo comum em processos de histeria (Klein, 1923).

Ademais, há, ainda, a negação, uma forma de defesa maníaca, que, muitas vezes, passa a ser o mecanismo adotado pelo sujeito para evitar o reconhecimento da própria doença e tornar desnecessário qualquer tipo de tratamento.

Sobre a utilização dessa forma de mecanismo de defesa, Mello Filho, em seu trabalho "Identidade Médica: o Normal e o Patológico", afirmou que a defesa maníaca é "utilizada a larga manu e se tornou mesmo um dos cacoetes típicos da classe médica, uma hipomania crônica que já faz parte da identidade profissional de muitos médicos" (Mello Filho, 2006).

Talvez não seja à toa que 32 (ou 7,3\%) inventários de depressão e 47 (ou 10,7\%) de ansiedade tenham sido zerados pelos sujeitos. Indiscutivelmente, podem refletir a ausência total e absoluta de qualquer sintoma depressivo ou ansioso no sujeito, mas não se pode deixar de considerar a possibilidade de ser esse dado um resultado da ação de mecanismos de defesa como a negação (uma forma de resistência), uma vez que é pouco provável que todos esses indivíduos não tenham apresentado nenhum dos sintomas descritos nas 21 alternativas dos testes durante os 7 dias que o antecederam. 
A falta de interesse, outra justificativa também observada no Questionário, parece indicar uma dissociação mente-corpo, como se o mundo interno e as questões emocionais não tivessem relevância e pudessem ser abolidos da realidade por terem menor importância ou serem insignificantes. É também uma forma de defesa maníaca, que carrega em si um desprezo pelas questões emocionais e psíquicas, e um triunfo sobre o sofrimento, tendo por finalidade tornar o sujeito mais forte e invulnerável.

Ainda que tenham reconhecido a demanda ou necessidade de receber auxílio psicológico, a maioria dos estudantes revelou o comportamento de não buscar esse serviço, justificando-o pela falta de tempo, ou pelo desconhecimento sobre o assunto ou sobre profissionais e locais que prestam esse serviço, e, até mesmo, pela falta de identificação ou empatia com a equipe do GRAPAL.

A análise dessas justificativas, de fácil contestação, mostra a superficialidade e fragilidade dessas, revelando a possibilidade de serem consideradas resistências à busca de auxílio psicológico.

A falta de tempo consiste numa racionalização, um mecanismo de defesa neurótico. Como é sabido, é muito utilizada de forma genérica e corriqueira por um indivíduo que quer evitar realizar um tipo de atividade indesejada ou para a qual não atribui muita importância ou valor, ou, ainda, que lhe pareça muito difícil de cumprir, e que não seja percebida como prioridade. Contudo, se a atividade é desejada ou considerada relevante, o sujeito sempre encontrará um tempo para realizá-la. Reforçam essa proposição as inúmeras atividades eletivas e extracurriculares para as quais os alunos sempre encontram tempo para realizar.

Além disso, a falta de tempo alegada pelos alunos em função da grade curricular imposta pela instituição é questionável e considerada pouco provável, uma vez que, de forma geral, os professores de todos os anos, incluindo os do internato, autorizam o aluno a ausentar-se de suas atividades quando necessitam ir a uma consulta no GRAPAL.

A citada falta de conhecimento sobre a busca de auxílio psicológico e sobre profissionais ou locais que prestam serviços de saúde mental também não parece uma justificativa consistente quando apresentada por essa população. Isso porque a existência do GRAPAL é informada a todos os alunos que entram na faculdade durante a semana da recepção. O GRAPAL, ainda, convida a todos os calouros para uma entrevista com os membros da equipe durante o primeiro ano do curso. Além disso, na página inicial do site 
da Faculdade, há um link de acesso ao site do GRAPAL, que contém todas as informações de acesso ao mesmo.

Mas, ainda que sua divulgação tenha sido falha, é sabido que a população universitária, de forma geral, conhece e utiliza quase que diariamente a Internet como fonte de pesquisa e informação. Pode-se, pois, considerar que o acesso a sites de pesquisa é um hábito quase que diário, muito difundido e ao alcance de qualquer estudante dessa faculdade, que poderia, então, pesquisar sobre os serviços dessa natureza que não se restringem ao GRAPAL, havendo muitos outros com o mesmo objetivo. Portanto, essa também seria mais uma forma de expressar a resistência em relação ao auxílio psicológico.

Outra maneira de manifestação da resistência são as justificativas apresentadas em relação ao GRAPAL, especialmente as baseadas na falta de empatia com os respectivos profissionais e/ou nas declarações de que não gostaram do atendimento. Essas alegações podem acontecer em qualquer tipo de atendimento no campo da Saúde, sendo considerado algo inerente à relação médico-paciente ou psicólogo-paciente.

Contudo, podem refletir, também, as limitações de um serviço. No caso do GRAPAL, há quatro profissionais para um público-alvo de 2.700 pessoas (alunos de Medicina, Fisioterapia, Terapia Ocupacional, Fonoaudiologia e residentes do HC).

Diante disso, parece muito difícil que esse grupo, isoladamente, supra todas as demandas de assistência psicológica dessa população, expectativa que, fantasiosamente, está presente nos alunos e, talvez, até mesmo, na própria instituição de ensino. Em relação a essa expectativa, é comum que surjam ideias de que, se não se pode fazer tudo, não se faz nada, dentro do binômio onipotência-impotência.

De acordo com os relatórios realizados sobre os serviços prestados pelo GRAPAL, foram contabilizados (até 2014) 26.453 atendimentos realizados durante os 28 anos de atividade, e uma redução em dez vezes do coeficiente de suicídio dos alunos nos últimos 26 anos, quando comparado aos 21 anos anteriores à criação do Serviço. Isso mostra que, embora pequeno, o grupo foi potente para realizar esse trabalho, e que, embora os resultados apontem para a existência de resistência pelos alunos dessa instituição na busca de auxílio psicológico, muitos sujeitos não apresentaram tal defesa, e puderam ser, efetivamente, atendidos e beneficiados pelos serviços prestados por esses profissionais.

Além disso, os estudantes que não gostaram do serviço oferecido por esse grupo sempre poderão buscar auxílio psicológico em outros lugares, como no Instituto de 
Psiquiatria desta Faculdade, assim como buscam outros serviços médicos no complexo do Hospital das Clínicas e com seus professores. Mas, além do Ipq e dos professores, o estudante também pode buscar outros profissionais no mercado com os quais poderia desenvolver empatia.

A vergonha e o medo de exposição também foram justificativas citadas pelos alunos. Consistem em manifestações diretas do preconceito desses sujeitos não só em relação à doença mental, mas, também, ao tratamento psicoterapêutico. Muitos alunos se queixam de serem hostilizados por colegas pelo fato de frequentarem o GRAPAL, mas, possivelmente, eles mesmos tenham esse preconceito.

O medo de exposição quanto ao sigilo é fantasioso, uma vez que nunca ocorreu nenhum caso de quebra de sigilo desde a criação do Serviço e todos os cuidados são tomados para que isso não ocorra. Para tanto, os prontuários não contêm o nome do aluno atendido, mas um número que o representa; o local em que funciona esse serviço é discreto e de pouca circulação a fim de evitar encontros indesejados.

Ainda foi citada a preguiça, outra forma evidente de resistência que se assemelha à falta de motivação e de interesse, defesa maníaca com predominância da desvalorização da doença mental e respectivo tratamento, e do triunfo sobre eles.

\subsection{Teste de Apercepção Temática}

"Tento comunicar o incomunicável, (...) falar algo que sinto apenas nos meus ossos e que só pode ser experimentado nestes ossos. F. Kafka"

\subsubsection{Embasamento teórico adotado na análise do TAT}

O embasamento teórico adotado na análise e interpretação do TAT fundamentouse na descrição do funcionamento psíquico proposto por Freud e nas contribuições de Melanie Klein. Assim, consideraram-se as instâncias consciente e inconsciente, e a descrição tópica e dinâmica do psiquismo.

\footnotetext{
${ }^{1}$ Frase pichada na parede do Porão (CAOC).
} 
Em termos tópicos, Freud divide o "aparelho psíquico" em três instâncias: Id, Ego e Superego, sendo que as duas últimas teriam partes conscientes e partes inconscientes, enquanto o id seria totalmente inconsciente (Freud, 1940).

O Id é descrito como a parte mais antiga destas localidades psíquicas. "Ele contém tudo o que é herdado, que se acha presente no nascimento, que está assente na constituição - acima de tudo, portanto, os instintos, que se originam da organização somática e que aqui [no Id] encontram uma primeira expressão psíquica, sob formas que nos são desconhecidas" (Freud, 1940).

Em razão da influência das forças ambientais, uma parte do Id desenvolveu-se e constituiu-se sob uma organização especial, que age como instância intermediária entre o Id e o mundo externo, e que se denominou Ego. As suas principais características são as seguintes: a autopreservação e os movimentos voluntários, em consequência da conexão entre percepção sensorial e ação muscular; ele avalia os acontecimentos externos, dando conta dos estímulos, armazenando experiências sobre eles (na memória), evitando estímulos excessivamente intensos (mediante a fuga), lidando com os estímulos moderados (por meio da adaptação) e, finalmente, aprendendo a produzir modificações convenientes no mundo externo, em seu próprio benefício, por meio da atividade ou ação (Freud, 1940).

Em relação ao Id, o Ego tem a missão de controlar as exigências dos instintos, decidindo se elas devem ou não ser satisfeitas, adiando essa satisfação para ocasiões e circunstâncias favoráveis no mundo externo ou suprimindo inteiramente as suas excitações. É dirigido, em sua atividade, pela consideração das tensões produzidas pelos estímulos, estejam essas tensões nele presentes ou sejam nele introduzidas.

A elevação dessas tensões é, em geral, sentida como desprazer, e o seu rebaixamento, como prazer. O Ego se esforça pelo prazer e busca evitar o desprazer. "Um aumento de desprazer esperado e previsto é reconhecido como um sinal de ansiedade; a ocasião de tal aumento, quer ele ameace de fora (mundo externo) ou de dentro (mundo interno, psíquico), é conhecida como um perigo" (Freud, 1940).

O Superego é formado a partir do Ego durante a infância, ao longo do período de dependência em relação aos pais, no qual se prolonga a influência parental. Na medida em que este Superego se diferencia do Ego ou se lhe opõe, constitui uma terceira força que o Ego tem de levar em conta. 
As ações advindas do Ego são bem-sucedidas quando satisfazem, simultaneamente, as exigências do Id, do Superego e da realidade, conciliando as exigências umas com as outras.

Em "O ego e os mecanismos de defesa”, Anna Freud apresenta o Ego como a instância de observação, apontando que os conteúdos do Id e do Superego só podem ser percebidos por meio das reações (defesas) advindas do Ego, que se contrapõem às demandas indesejáveis do Id e do Superego, isto é, em situações em que se verifica um conflito entre essas instâncias (Freud, 1996).

Do ponto de vista tópico, “o processo primário caracteriza o sistema inconsciente e o processo secundário o sistema pré-consciente e consciente. Do ponto de vista dinâmico, no processo primário, a energia psíquica escoa-se livremente, passando sem barreiras de uma representação para outra segundo os mecanismos de deslocamento e de condensação; tende a reinvestir plenamente as representações ligadas às vivências de satisfação constitutivas do desejo (alucinação primitiva)". No processo secundário, "as representações são investidas de uma maneira mais estável, a satisfação é adiada, permitindo, assim, experiências mentais que põem à prova os diferentes caminhos de satisfação" (La Planche e Pontalis, 2000).

Os conteúdos inconscientes são aqueles que não podem ser aceitos pelo Ego. Isto quer dizer que o Ego ou "EU" dos indivíduos não aceita ser possuidor de certas características ou desejos, por considerá-los imorais e inaceitáveis à sua personalidade. Essas ideias ou esses desejos inaceitáveis são submetidos a determinados mecanismos de defesa que tentam, de alguma maneira, afastá-los ou retirá-los da consciência e do conhecimento do indivíduo (Freud, 1996).

Nesse sentido, a expressão "ideal de ego" passou a ser utilizada por Freud como um elemento do superego, consistindo numa instância crítica resultante de identificações com os pais, seus substitutos e com os ideais coletivos. Consiste numa representação de si mesmo onipotente muitas e, vezes, irreal. (http://www.medicinapsicossomática.com.br/glossário/internalização.htm).“Enquanto instância diferenciada, o ideal do ego constitui um modelo a que o sujeito procura conformar-se" (La Planche e Pontalis, 2000).

A expressão "Ideal de Ego" foi usada por Freud em sua segunda tópica, muitas vezes, como sinônimo de "Superego", mas é utilizada por outros autores com sentidos diferentes; "o superego corresponde à autoridade e o ideal do ego à forma como o sujeito 
deve comportar-se para corresponder à expectativa da autoridade" (La Planche e Pontalis, 2000).

Em Sobre o narcisismo: uma introdução, Freud coloca que o "desenvolvimento do ego consiste num afastamento do narcisismo primário e dá margem a uma vigorosa tentativa de recuperação desse estado. Esse afastamento é ocasionado pelo deslocamento da libido em direção a um ideal do ego imposto de fora, sendo a satisfação provocada pela realização desse ideal" (Freud, 1914). Esse autor, ainda, explica que a autoestima seria formada uma parte pelo resíduo do narcisismo infantil, outra pela satisfação da libido objetal, e uma outra parte seria decorrente da onipotência corroborada pela experiência de realização do ideal de ego. (Freud, 1914).

Ele aponta, ainda, a importância do ideal de ego na compreensão da psicologia de grupo. "Além do seu aspecto individual, esse ideal tem seu aspecto social; constitui também o ideal comum de uma família, uma classe, uma nação" (Freud, 1914).

Contudo, não parece ser tarefa fácil realizar o ideal de ego, este, como declara Freud no texto acima citado, "impõe severas condições à satisfação por meio de objetos, pois ele faz com que alguns deles sejam rejeitados por seu censor como sendo incompatíveis".

\subsubsection{Observações iniciais}

De forma geral, os alunos que compareceram ao teste se mostraram dispostos a realizar a atividade. Um deles disse que estava ali atendendo a solicitação feita por uma professora. Outro disse que, depois que um parente diagnosticado com TOC havia feito psicoterapia, havia perdido o preconceito. Um terceiro sujeito disse que havia ido ao GRAPAL uma vez, mas como não conseguiu um horário próximo, acabou desistindo de voltar. Os demais não fizeram nenhum comentário.

Embora tenha sido pequena a amostra dos alunos que realizaram o TAT, com apenas 7 sujeitos (Tabela 24), a análise qualitativa dos testes revelou alguns dados comuns. Nenhum dos sujeitos que realizaram o TAT apresentaram escores em nível Moderado para ansiedade e depressão (Tabela 25); e todos afirmaram no Questionário que tiveram interesse em buscar algum tipo de atendimento psicológico, mas não o fizeram. As justificativas alegadas no Questionário foram variadas: "não tive tempo", "não tenho segurança/disponibilidade", "acabei deixando pra lá", "preguiça”, "não foi 
necessário", "até há algumas semanas pensava nesse caso, mas, com as provas e demais acontecimentos pessoais, sinto-me motivada", "preços e agenda conflitante".

Esse fato pode ser compreendido em razão da resistência que, embora tenha impedido o efetivo acesso desses sujeitos ao atendimento, não foi forte o suficiente para impedi-los de reconhecer a própria demanda e comparecer ao TAT.

De maneira geral, os alunos não tiveram dificuldade em realizar o teste, apenas uma aluna mencionou que achou difícil inventar as histórias, salvo na primeira prancha.

\subsubsection{Análise e interpretação das pranchas}

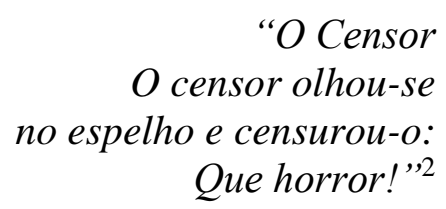

Por tratar-se de um teste projetivo, conteúdos inconscientes e aspectos psíquicos de ordem variada podem ser observados por meio dessa atividade. Porém, não é do interesse desse trabalho investigar a personalidade dos sujeitos que dele participaram, mas sim observar os aspectos que, possivelmente, estivessem relacionados à resistência desses sujeitos em acessar algum tipo de serviço psicológico.

Nesse sentido, foram aqui discutidas as angústias/ansiedades mais evidenciadas com o teste, que pudessem originar as defesas psíquicas capazes de influir na resistência da busca por auxílio psicológico.

A primeira delas diz respeito à angústia de não conseguir realizar uma tarefa, veiculada, principalmente, na Prancha 1, mas, também, observada em outras pranchas.

Esta é a prancha cujo estímulo é considerado o mais estruturado dentre todos os outros e por isso a que desperta menos angústia, sendo, pelo mesmo motivo, a primeira prancha a ser apresentada ao sujeito do teste.

Esta parece ter sido, dessa forma, a prancha mais fácil para todos os sujeitos. Isso explica não terem sido observadas nessa prancha interjeições (expressões de angústia, como: “nossa, o que é isso!!!” ou “essa tá difícil”) por nenhum dos 7 alunos. Em geral,

2 Poema de Carlos D. de Andrade encontrado em cartaz colado na parede do CAOC. 
essa prancha também apresentou o melhor resultado quanto ao critério "integração do ego" (Tabela 26), sendo classificada como "boa" (2 sujeitos) e "razoável” (3 sujeitos), e na qual se constatou a menor frequência de histórias sem desfecho (Superego não evidente, conforme Tabela 27), uma das orientações que deveriam ser atendidas pelos alunos ao criarem a história solicitada.

De acordo com o autor, essa prancha evoca a angústia frente à realização de uma tarefa, fato observado nas histórias contadas pelos 7 alunos. Isso pode ocorrer por estar essa angústia mais próxima à consciência desses sujeitos.

Um dos aspectos associados à resistência à busca por auxílio psicológico diz respeito à angústia de não realização de tarefas, uma vez que deflagra o receio do sujeito em não realizar o ideal do ego e não conseguir, assim, a satisfação almejada (Freud, 1914). O medo do fracasso (em realizar uma tarefa) defronta o sujeito com a possibilidade de experimentar a frustração, que, é a "condição do sujeito a quem é recusada, ou que recusa a si mesmo, a satisfação de uma exigência pulsional" (La Planche e Pontalis, 2000).

O exemplo a seguir ilustra bem essa angústia:

Aluno 3:

“Um menino novinho, angustiado por querer fazer certo e não conseguir... "(sic)

A angústia de realização de tarefas está relacionada a uma demanda superegoica, que impõe a tarefa como um dever ou obrigação que, de tão intensa, passa a ser sentida pelo sujeito como uma necessidade. Também decorre das exigências do ideal de ego, que, originado do narcisismo primário, engloba o medo de perda de amor pelos pais (Freud, 1914). 
Aluno 4:

"Eu imaginei que a mãe dele disse que ele tinha que aprender a tocar um instrumento e levou o violino para ele, e ele tá meio inseguro. Nesse momento ele está analisando se vai conseguir ou não. Mas acho que ele vai tentar..."(sic)

Aluno 2:

"Ele tinha, como se fala, uma audição importante mas achava que não tava conseguindo tocar bem, e a professora estava no pé dele. Ele tá meio frustrado porque não consegue tocar do jeito que queria. Ele tá tentando melhorar mas está cansado. Ele olha preocupado para o violino porque sabe que tem que praticar para se apresentar bem. "(sic).

A impossibilidade da realização da tarefa gera uma angústia relacionada não só ao fracasso, mas também à incapacidade e à impotência. A frustração gera desprazer, muitas vezes, sentido como raiva e/ou culpa. De acordo com Klein, a experiência de não ser satisfeito agrega ao objeto frustrador qualidades ruins e o transforma em um perseguidor, gerando, muitas vezes, a ansiedade paranoide (Klein, 1935).

Ademais, como mencionado no Embasamento Teórico supracitado, o superego é formado por meio da internalização das exigências e interdições parentais, de autoridades, relacionando-se à censura e à castração. Tem como função a formação da consciência moral, a auto-observação e a formação de ideais. "Seu papel é assimilável ao de um juiz ou de um censor relativamente ao ego" (La Planche e Pontalis, 2000). Analogamente, o ideal de ego também recebe influências parentais, e funciona como órgão de censura, por isso diz-se que é imposto por influências de fora (externas) e corresponde à forma como o sujeito deve comportar-se para corresponder à expectativa da autoridade. Os exemplos a seguir mostram a manifestação desses elementos na angústia relacionada à execução de tarefas.

Aluno 7:

“Um menino que está estudando violino, parece cansado, triste, deprimido. Me dá a sensação de que os pais têm vontade que ele estude violino mas ele mesmo não tem nenhum interesse...".(sic) 


\section{Aluno 5:}

"Esse menino... acabou de ganhar um violino do pai, que gostaria que ele aprendesse a tocar violino. O pai é bastante exigente, quer que ele seja bom aluno, que estude inglês, informática, que tenha uma educação bem abrangente. Mas ele não gosta de música... A princípio ele vai tentar aprender para agradar o pai, mas vai chegar uma hora que ele vai parar de tentar. Vamos ver se o pai é compreensivo...." (sic).

O desejo (ou a necessidade) de agradar a figura paterna, que esconde uma submissão às exigências superegoicas ou a seus substitutos, tem por objetivo garantir o amor desses e, assim, a própria segurança e satisfação. Pode também servir como reparação à figura parental que fora anteriormente atacada e danificada na fantasia inconsciente.

A não realização da tarefa ou obrigação imposta, a contrário senso, pode estar associada à culpa pela danificação do objeto amado. Assim, a atividade "tocar violino" deve ser cumprida a fim de agradar aos pais (ou seus substitutos)/instância superegoica, pois, de outra forma, estaria o sujeito realizando o inverso, decepcionando-os, frustrandoos, ou, na fantasia, atacando-os (mãe e/ou pai ou substituto). Consequentemente, a vivência experimentada é de culpa e ansiedade persecutória (medo de que o objeto amado anteriormente atacado se vingue, voltando-se contra o agressor).

Esse tipo de funcionamento psíquico consiste em uma fantasia primitiva, relacionada à posição esquizo-paranoide (Klein, 1923), em que predomina a relação com objetos parciais (que ou são bons, quando gratificam o sujeito; ou são maus, quando frustram).

A realização da tarefa exigida pela instância superegoica aparece como uma necessidade para livrar o sujeito de críticas e castigos, bem como, da sensação de culpa e perseguição, da qual só estará a salvo se o superego não for tão rígido e se apresentar mais flexível - "A princípio ele vai tentar aprender para agradar o pai, mas vai chegar uma hora que ele vai parar de tentar. Vamos ver se o pai é compreensivo...."(sic) (Aluno 5, Prancha 1).

A busca por auxílio psicológico, como visto anteriormente, é, frequentemente, associada à fragilidade do caráter e ao fracasso pessoal; algo que deve ser evitado pelo sujeito que não pode aceitar a frustração, sob pena das angústias que serão, então, despertadas. Dessa forma, a busca por um tratamento psicológico pode ser facilmente 
interpretada pelo sujeito como a concretização do fracasso pessoal, pois, a contrário senso, caso ele tivesse realizado e satisfeito o seu ideal de ego/superego, ele sentiria um grande prazer e acréscimo em sua autoestima (Freud, 1914).

Outra possibilidade de interpretação da Prancha 1 é em relação à situação frente ao teste ou a uma situação desconhecida, que também poderia ser, por analogia, a situação de psicoterapia ou de algum atendimento nessa área. Nesse caso, os exemplos revelam que, apesar de não terem interesse ou não gostarem da atividade, eles a realizam, ainda que para atender a um "senso de obrigação que tenham dentro de si" (exigência superegoica):

Aluno 6:

“... Mas além de cansaço, parece que ela está com desinteresse pelo que ela faz agora... Eu não sei o que é. Não consigo reconhecer esse objeto, mas parece que ele não está aqui por vontade própria. Acho que é isso... Ou é por pressão dos pais ou por um senso de obrigação que ela tenha dentro de si” (sic).

Assim, a reação frente ao teste, por analogia e proximidade (trata-se de um teste de personalidade e, portanto, psicológico; a aplicadora do teste era uma psicóloga), pode ser estendida à ação de procurar auxílio psicológico. Depreende-se, então, que os alunos podem realizar uma transferência dos conteúdos projetados não só na figura do pai/superego, mas, também, na do psicólogo ou a tudo a que ele se relacione, como o GRAPAL ou qualquer serviço de apoio psicológico. Pelo mecanismo de transferência, as exigências do superego e/ou do ideal do ego são deslocadas ao psicólogo/psiquiatra, que fica empossado no papel de censor, ou seja, aquele que avalia, fiscaliza, condena e pune o sujeito que não atende a suas exigências.

Esse mecanismo atrapalha, ou, até mesmo, impede que o sujeito possa entrar em contato com as fantasias que foram reprimidas e retiradas da consciência, e que não podem ser reveladas por não atenderem às exigências do ideal de ego. Trata-se de um mecanismo de defesa do tipo transferencial, cujo manejo demanda o contato com o paciente, sem o qual não pode ser trabalhado.

Não obstante, tanto o teste como o trabalho do analista/psiquiatra fluem no sentido contrário, de trazer à consciência aquilo que foi reprimido porque fora considerado pelo sujeito como algo ruim (como a falha pessoal), que não pode ser aceito pela consciência 
(e por si mesmo); e isso, por si só, já ameaça o ego e provoca o aumento da resistência no indivíduo.

Ao contrário da Prancha 1, a Prancha 8RM (Intervenção Cirúrgica) parece ter sido a que despertou mais angústia nos sujeitos: nela, observou-se o maior número de interjeições: "Caramba!! O que é isso?” (Aluno 1), "Nossa! Esquisita essa! Nem sei te dizer o que acontece... Parece uma coisa muito louca!" (Aluno 3), "Ahmmm... Muita coisa aqui... Isso faz parte da cena?”, (Aluno 4), "Engraçado, essa foto não faz sentido! Não consigo pensar numa boa situação...Não sei nem o que estou vendo." (Aluno 7).

Em relação ao critério “integração do ego", este, de maneira geral, apresentou-se predominantemente menos estruturado (entre Fraco e Regular) e o Superego não pode ser evidenciado em 5 das 7 histórias, tendo sido nelas omitido. Esses dados são indicadores do impacto do ego frente a um estímulo demasiadamente ameaçador à sua organização e sua dificuldade em lidar com tal estímulo.

Essa prancha traz o tema da agressividade e evoca as ansiedades a ele associadas, que são relacionadas aos aspectos menos desenvolvidos do psiquismo humano.

Essa prancha também foi a que apresentou o maior número de histórias com pouca ou sem coesão. A maioria das histórias contadas se limitava à descrição da percepção do desenho, sem apresentarem início e desfecho. Um aluno apresentou uma distorção de percepção: a personagem vestindo terno e gravata que aparece em primeiro plano foi percebida como uma menina pelo Aluno 3: “Uma menina de 16 anos...”(sic). Outro aluno não pode integrar a personagem à história: “...e há um rosto à direita da fotografia vestido de terno e gravata com um olhar sem muita expressão. Não consigo ver relação dele com o resto da fotografia" (sic) (Aluno 6).

Isso pode ter ocorrido por terem os sujeitos, estudantes de Medicina, se identificado de forma intensa com o estímulo que retrata uma cirurgia. Este parece ter impactado os sujeitos, despertando-lhes angústias e defesas que impediram o atendimento à proposta do teste (contar uma história, com começo, meio e fim, descrevendo os pensamentos e sentimentos das personagens). A ausência de desfecho nessas histórias implicou na impossibilidade de evidenciar a qualidade do superego, o que foi observado nos relatos de 5 dos 7 sujeitos.

As situações referidas por todos os sujeitos, nessa Prancha, indicaram aspectos psíquicos relacionados à agressividade (... Eu vejo uma arma, o que me dá a sensação de que estão num combate ou numa guerra”, "Isso parece uma arma, mas não sei se é. Acho 
que é o trabalho dele, ele era caçador e acabou se machucando porque foi caçar um animal...”), sadismo (“...Me parece um ato cirúrgico sendo efetuado, contudo não me parece anestesiado, pelo semblante de sofrimento em seu rosto..."), impotência ("Eu diria que esse menino perdeu o pai nesse combate e tá indignado, dessas guerras que a pessoa que está lutando tem pouco a ver com os motivos da guerra ou com a questão que está por trás dela...”), sofrimento (“...Parece uma cirurgia e a pessoa que tá deitada tá com um rosto de dor..") e morte ( “Acho que essa pessoa morreu ou está para morrer”).

Além desses conteúdos de cunho agressivo, a maioria dos sujeitos identificou-se com o doente/paciente, que está vivenciando uma cirurgia, uma situação de sofrimento. Essa imagem, quando transferida para a situação do teste ou analogamente à de atendimento psicológico, coloca o estudante na posição daquele que está sendo objeto de uma intervenção, em que se busca ver aquilo que está dentro, o que é interno, o que está escondido.

Nesse sentido, o trabalho da análise (ou auxílio psicológico) parece ser percebido como algo invasivo e capaz de impingir um certo grau de dor e sofrimento, e, nesse sentido, se assemelha ao trabalho de um cirurgião: “O tratamento psicanalítico pode ser comparado a uma operação cirúrgica e exigir, de modo similar, que seja efetuado sob condições que serão as mais favoráveis para seu êxito...” (Freud, 1917).

Dessa maneira, o estudante de Medicina poderia estar aqui revelando sua resistência já observada em outros estudos, relacionada a aspectos da identidade médica, em que é difícil ao médico passar desse papel para o de paciente (Meleiro, 1999, NogrueiraMartins, 1996).

Outro aspectos notado especialmente na Prancha 7RH - "Pai e Filho" - refere-se à competitividade, que, embora indiscutivelmente constitua uma característica de personalidade desejável, em excesso, pode apresentar-se como prejudicial ao desenvolvimento do indivíduo, pois agrega comportamentos destrutivos, como a raiva, a disputa, a desvalorização do indivíduo e o triunfo do vencedor. 
Numa relação médico-paciente, bem como entre psicoterapeuta e cliente, a presença desse tipo de sentimentos torna a terapia mais difícil, pois a transferência que se instala é negativa e o sujeito (inconscientemente) tende a atacar o vínculo terapêutico, tornando mais difícil (se não impossível) o trabalho (psico)terapêutico.

A competitividade, a raiva e o conflito podem ser notados por meio dos seguintes trechos extraídos das histórias contadas sob o estímulo da Prancha 7RH:

\section{Aluno 1:}

“Como os personagens chegaram a esse ponto? Eles trabalham numa empresa. $O$ mais novo está de saco cheio e eles estavam discutindo, mas não chegaram a nenhum acordo" (sic).

\section{Aluno 2:}

"Sei lá, parece que ele tá olhando alguém com raiva. E o outro, mais velho, parece que tá concordando... Esse outro cara, não sei se concorda de fato, parece que ele quer falar mal da outra pessoa. Parece meio manipulador esse cara com bigode. Mas esse outro parece que está com raiva, insatisfeito." (sic).

Esses sentimentos naturais de qualquer ser humano podem ficar mais intensificados durante a adolescência, em que diversos processos maturativos, fisiológicos e psíquicos são retomados. Sentimentos relacionados à competição e raiva não são aceitos facilmente pelo ego, principalmente por aqueles que possuem um superego rígido e um ideal de ego elevado. Esses sentimentos são socialmente mal vistos e moralmente condenados. A censura e a moral (Superego), então, impedem o seu reconhecimento como parte integrante do Ego, que faz emergir defesas como a negação, cujo objetivo é suprimi-los ou descaracterizá-los de alguma forma.

Mas não é apenas por questões morais que sentimentos como a raiva e a agressividade não podem ser aceitos pela consciência. Há, ainda, o sofrimento advindo dos sentimentos de culpa, conforme descrição anterior sobre a Posição esquizo-paranoide (Klein,1923), bem como, o desconforto ao se experimentarem aspectos como o sadismo, a voracidade e a frustração.

As angústias ligadas a esses aspectos de rivalidade, raiva e competição também foram percebidos na prancha seguinte, 9MF (“Duas Mulheres na Praia”): 
Aluno 7:

“Complicada essas fotos. Também tô com muita dificuldade em criar um contexto com essa aqui... acho que vou dar um tom de filme, de novela. Dá a impressão que duas mulheres jovens, por volta de uns 30 anos talvez... me dá a sensação que a mulher de cima, mais próxima, arquitetou um plano para a menina de baixo e tá observando a menina de baixo que tá correndo em direção a alguma coisa. Dá a sensação de que a de cima fez uma pegadinha pra outra. Me lembra o filme do Rei Leão que me marcou muito quando eu era pequeno, que tinha a história do tio Scar que planejou uma armadilha e tramou a morte do irmão Mufaza, que era o pai do Rei Leão. Essa de cima me dá a mesma impressão, de ter arquitetado alguma coisa para prejudicar a de baixo...Não sei se consigo bolar um história mais específica do que ela estaria tramando para prejudicar a outra. Uma coisa que eu presencio bastante em conflitos entre mulheres é em relação aos homens, então eu acho que a mulher de cima ficou falando coisas desagradáveis que o namorado ou o marido da outra tenha feito, falou coisas ruins sobre essa pessoa, criou uma situação falsa para essa menina, para acabar com o relacionamento dela, talvez. porque também esteja interessada na mesma pessoa, ele tenta posar de amiga mas não é nada disso" (sic).

Uma das maneiras que o ego encontra para se livrar desses sentimentos é a dissociação e a negação, entre outros. Na Prancha 9MF ("Duas Mulheres na Praia”), pode se notar o trabalho da dissociação:

Aluno 5:

"Parece que elas são a mesma pessoa e a que tá atrás da árvore está usando uma roupa de empregada, como se fosse uma camareira, alguma coisa assim e embaixo é uma mulher que deve ser ela mesma. Ela está observando a outra fugir com uma roupa mais ousada, fugindo, como se ela quisesse ser outra pessoa e fugir.

Antes ela tava trabalhando e se sentindo infeliz com a vida dela pelo jeito que ela tá, pensando... Acho que ela vai continuar seguindo a vida dela e não vai fazer o que deseja e não vai ser a mulher que ela quer" (sic). 
Aluno 1:

"São duas moças. Uma corre e a outra observa a que está correndo... A que corre quer alcançar algum lugar ou alguém... a que observa está tentando descobrir algo, mas não sei o que é... A que corre não pensa em nada. Mas a que observa está pensando numa equação matemática...”.

O mesmo foi observado na história contada pelo Aluno 2, que também realiza a dissociação entre impulsos agressivos, projetados na moça que corre, e aspectos mais racionais e conciliadores, projetados na outra personagem:

Aluno 2:

"Essas moças parecem estar correndo... A moça de baixo não está segurando nada além do vestido, então a outra deve estar segurando o material da moça de baixo. A moça de baixo, sem material, parece que está brava ou confiante e quer correr para chegar logo...ela parece ser um pouco impulsiva, como se diz daquela pessoa que faz primeiro e depois pensa... Ela (a outra moça que aparece num plano superior) tá tentando ajudar a amiga... Elas chegam na escola e a moça que está correndo briga com o professor e com algumas colegas..."

Já a última prancha aplicada, Prancha 12 H, denominada “O Hipnotizador”, evoca ansiedades relacionadas à passividade e impotência frente as figuras de autoridade, e em relação à situação de (psico)terapia, bem como, à situação do teste. Embora não seja o foco nem o interesse desse estudo, pode também dar indicações de tendências homossexuais, o que não foi aqui investigado.

Dos 7 alunos que responderam o teste, dois (um aluno e uma aluna) apresentaram sentimentos hostis e depreciativos em relação à figura do hipnotizador (autoridade), percebido como um perseguidor e como um velho incapaz e dependente.

Aluno 2:

"Parece que esse cara calvo (homem em pé) pensa que tem um espírito ruim no menino que está deitado. Mas o menino não acha isso, ele acha que está tudo bem com ele, mas o cara em pé acha que tem que 'mudar' o menino deitado. 
O menino, ele tá irritado, de olhos fechados, está tentando ignorar o homem calvo. Mas o homem calvo foi até a cama dele só pra perturbar, pra tirar o que há de ruim, mas ele (homem calvo) acha que tá fazendo a coisa certa. Mas o menino acha que não, ele queria que o homem fosse embora. É capaz que o menino se irrite e levante da cama dele e vá dormir em outro lugar só pro cara ficar longe dele” (sic).

Diante das angústias despertadas por esse estímulo, pode-se deduzir a ação da resistência em relação ao auxílio psicológico, uma vez que esse sujeito, identificado com a personagem infantil (menino deitado), percebe o adulto (o hipnotizador/psicoterapeuta) como um perigo, uma ameaça ao seu próprio ego, uma vez que deseja mudar algo (ruim) que vê ou percebe existir dentro do menino, e que é por este negado. A defesa adotada pelo menino é a evitação e o afastamento dessa personagem que o enxerga por dentro e por isso o incomoda.

Aluno 3:

"Hummm... De novo imaginei pai e filho ou vô e neto que moram juntos. O avô é um homem meio debilitado que precisa de certa ajuda para fazer tudo. Ele fica em casa o dia todo sozinho. O filho acabou de chegar em casa muito cansado e foi deitar um pouco e o pai está com receio de acordar o filho, mas ele precisa de ajuda acho que pra ir ao banheiro e ele tá receoso em acordar o filho e atrapalhar o descanso dele ou incomodá-lo. Talvez o filho já tivesse meio aborrecido com alguma situação, demonstrando que estava cansado, porque trabalha muito e chega em casa e ainda tem que cuidar do pai, mas este agora precisa acordar o filho e está meio receoso em fazer isso... Ele dormiu e o pai vai desistir de acordar o filho por medo da reação do filho. Ele vai tentar fazer o que precisa, ir no banheiro, sozinho, mas não vai dar certo”. (sic)

Nesse trecho, o aluno percebe a figura do menino, embora numa posição de passividade (deitado), como o provedor, investido de potência e detentor da força e capacidade para o trabalho, enquanto a figura do hipnotizador (que está em pé), ao contrário, aparece destituído de qualquer valor, quase que totalmente impotente e sozinho, carente de recursos, força e autonomia; numa posição de extrema fragilidade, não sendo capaz nem mesmo de ir ao banheiro sozinho. 
Dessa forma, a resistência apresentada por esse sujeito age no sentido de desvalorizar a figura dessa autoridade/psicoterapeuta, retirando-lhe qualquer qualidade e capacidade produtiva, e tornando-o, aparentemente, uma figura desnecessária, que não tem qualquer serventia.

Por outro lado, dois outros sujeitos (Aluno 1 e 5) revelaram, nessa prancha, a projeção de aspectos positivos em relação à figura do hipnotizador, que aparece como alguém que oferece ao menino coisas boas, como alimento e bênçãos.

Aluno 1:

“Ahmmm... Antes do presente momento, o mocinho que está deitado tinha trabalhado o dia inteiro e tinha se decepcionado com algo e resolveu deitar em praça pública... Ele estava numa praça pública, deitou e ficou lá. O outro personagem antes de chegar lá tava cozinhando, não era algo de sobrevivência, sei lá, tava cozinhando na casa dele. Daí a gente vê o que está acontecendo agora: ele está com a mão levantada na direção do menino, mas não é um gesto ameaçador. Ele quis tirar um besouro do cabelo do garoto ou o garoto lembra alguém que ele gosta e quis se reconhecer no garoto. Ele tem afeto pelo menino e quis expressar isso. Ele tá pensando que o garoto tem um bonito rosto. O rapazinho está sonhando com um tipo de sonho em que você tenta fazer as coisas mais fica impedido ou um tipo de sonho em que você trava relações não muito amigáveis com outras pessoas, tipo brigando ou sendo incompreendido, uma gama de questões...”.

Psicóloga: “-E, depois, o que acontece?”

Aluno 1: “- O garoto acorda ao ser tocado, se senta no chão e incrivelmente não faz qualquer pergunta para o homem mais velho, nem se sente assustado. O homem mais velho pergunta se ele quer alguma coisa que ele cozinhou e oferece o que fez na cozinha anteriormente."

Psicóloga: “ - O menino aceita?”

Aluno 1: “-Não sei...”

Nesse trecho, o aluno projeta na figura do menino sentimentos de cansaço, incompreensão e de um conflito interno revelado por meio do sonho relatado. $O$ hipnotizador aparece como uma figura cuidadora, que oferece ao menino um alimento. Embora haja uma percepção positiva e favorável ao hipnotizador/psicoterapeuta, em que 
o alimento oferecido é o autoconhecimento, a resistência continua presente, pois a personagem não sabe se irá ou não aceitar esse alimento.

\section{Aluno 5:}

Aqui é um vô fazendo uma oração pro neto e parece que ele tem bastante afeto pelo neto. Acho que o neto não parece que está muito doente, é um quadro simples, mas o vô tá preocupado; como minha avó fazia comigo, ele veio rezar pro neto antes dele ir dormir. E depois vão continuar com a vida normalmente. Antes disso talvez o neto estivesse um pouco adoecido, mas nada grave e o avô foi fazer uma oração para ele, como fazia talvez todos os dias" (sic).

Neste trecho, a personagem do menino aparece doente enquanto a personagem do hipnotizador assumiu a figura de um avô (avó) que se preocupa com o neto e tem afeto por ele. Este consegue expressar esse afeto por meio de uma oração na hora de dormir, o que sugere a presença de uma angústia de separação e tudo o que é a ela inerente por parte do menino adoentado. Apesar da relação positiva associada à figura do hipnotizador, o trecho apresentou uma história pobre e pouco desenvolvida em relação aos sentimentos do menino, personagem com quem o sujeito se identificou. Parece que o sujeito tem uma leve percepção da necessidade de auxílio psicológico, pois projeta no menino uma doença leve, que pode estar sendo minimizada (normalizada) para justificar a falta de necessidade de uma intervenção que vá além das providências rotineiras (uma oração).

Os outros 3 alunos contaram histórias semelhantes nessa prancha. Para eles, o menino deitado foi percebido como morto, o que pode revelar sentimentos de desesperança em relação ao auxílio psicológico: "De repente é o avô, pai, chateado pelo adoecimento de alguém mais novo. Não é a ordem certa, mas Deus abençoe, descanse em paz."(sic) (Aluno 2); "Pode ser também que a pessoa deitada em questão tenha acabado de falecer e o senhor tenha acabado de fechar seus dois olhos com sua mão direita. Não dá para ter certeza porque o rosto do senhor não aparece na imagem" (sic) (Aluno 4); "Parece o pai vendo o filho morto, que faleceu por alguma razão, algum trauma, uma pessoa maldosa que matou esse menino e o pior é o pai vendo isso, que é uma questão antibiológica, de um pai ver um filho morto”(sic) (Aluno 6). 
Assim, de maneira geral, o TAT confirma os resultados do BAI, BDI e Questionário, que, em relação a esses 7 sujeitos, revelam que eles possuem a percepção de possuírem algum nível de angústia e sofrimento que os fizeram pensar em buscar ajuda psicológica, mas que, ao mesmo tempo, é difícil para eles aceitarem.

Essas angústias parecem estar relacionadas a sentimentos e fantasias inconscientes relacionadas à raiva, agressividade, e impotência, que são censuradas por serem inaceitáveis à consciência e ameaçadoras à própria identidade em formação.

Nesse sentido, a busca por auxílio psicológico parece estar na "contramão" do esforço por eles realizados, no sentido de negar as dificuldades, os receios e as inseguranças experimentadas nesses seis anos de grande crescimento e grandes transformações. 
6 CONCLUSÕES 


\section{CONCLUSÕES}

1 Os resultados revelaram 24 alunos (ou 5,5\%) com transtorno de ansiedade em nível moderado e $18(4,1 \%)$ com depressão em igual nível, sendo que, dentre esses, 6 sujeitos apresentaram comorbidade (BAI e BDI $\geq 20$ ).

2 O Ciclo Básico apresentou a maior frequência de sujeitos ansiosos (com ansiedade em nível leve e moderado $(p=0,01)$, e o Ciclo Clínico apontou a maior frequência de sujeitos deprimidos (com depressão em nível leve e moderado). Os menores índices de ansiedade (nível leve) foram encontrados entre os sujeitos do Internato, e o Ciclo Básico apresentou os menores índices de Depressão.

3 Foi observado que os sujeitos do gênero feminino apresentaram mais ansiedade dos que os do gênero masculino $(p=0,010)$. Não se observou diferença entre os gêneros em relação à incidência de depressão.

4 Dos 433 sujeitos que compuseram a amostra estudada, 218 (50,3\%) demonstraram interesse ou necessidade em receber algum tipo de auxílio psicológico durante a graduação, sendo que apenas $72(16,6 \%)$ sujeitos informaram já ter acessado esse tipo de serviço no mesmo período.

5 Não foi observada relação entre a intensidade dos sintomas depressivos ou ansiosos e a resistência na busca por auxílio psicológico, de forma que ela ocorre independentemente do nível do sintoma. Porém, constatou-se uma relação diretamente proporcional entre o aumento da intensidade dos sintomas tanto ansiosos como depressivos e a demanda ou reconhecimento da necessidade em receber auxílio psicológico.

6 Detectou-se resistência à busca por auxílio psicológico por parte de alguns alunos e os principais aspectos que podem estar a ela relacionados são certas características de personalidade, como a autoexigência, o perfeccionismo, a competitividade e a percepção de que há uma diferença entre a maneira como o sujeito gostaria de ser (ideal de ego) e como ele é. 
7 ANEXos 


\section{ANEXOS}

7.1 ANEXO A - Questionário

1 - Em algum momento da sua graduação você procurou o GRAPAL espontaneamente ou por interesse próprio?

$\operatorname{SIM}($ ) NÃO ( )

Se SIM, você concluiu o tratamento? SIM ( ) NÃO ( )

Se NÃO, qual foi o motivo?

2- Em algum momento de sua graduação você procurou algum tipo de serviço ou auxílio psicológico/psiquiátrico?

$\operatorname{SIM}($ ) NÃO ( )

Se SIM, você concluiu o tratamento? SIM ( ) NÃO （ )

Se NÃO, qual o motivo?

3- Alguma vez, durante o período da graduação, você sentiu vontade ou necessidade de procurar algum profissional (da área de saúde mental), diferente de colega, professor ou parente, para conversar sobre alguma questão pessoal que lhe tenha gerado preocupação, insegurança ou ansiedade?

SIM ( ) NÃO ( )

Se SIM, você procurou auxílio?

$\operatorname{SIM}($ ) NÃO ( )

Você concluiu o tratamento procurado? SIM ( ) NÃO ( )

Se NÃO, qual o motivo?

4- Você já recebeu algum tipo de sugestão, encaminhamento ou recomendação para iniciar ou fazer algum tipo de psicoterapia ou procurar algum especialista da área da saúde mental e mesmo assim não procurou?

Isso já me aconteceu ( )

Isso não me aconteceu

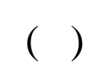




\subsection{ANEXO B - Carta convite}

Prezado aluno,

Dando continuidade à pesquisa sobre a caracterização da resistência pela busca de atendimento psicológico pelo aluno de medicina, gostaríamos de convidá-lo a participar da segunda fase dessa pesquisa, que corresponde à aplicação do Teste de Apercepção Temática (TAT) de Murray.

Esse teste dispensa qualquer tipo de preparo por parte do participante e não será aplicado em sua forma integral, mas reduzido a apresentação de 05 (cinco) gravuras ao aluno participante. O teste consiste na solicitação feita ao aluno para que conte uma história sobre a gravura que lhe foi apresentada, que será anotada pelo pesquisador e devidamente guardada para posterior análise.

Essa atividade não deverá exceder o tempo de 30 minutos e poderá ser agendada nos meses de setembro e outubro em data e horário que melhor lhe convier, através do telefone 3061-0312 ou e-mail annaluci@uol.com.br, diretamente com a pesquisadora e aplicadora do teste.

Informamos que quaisquer dúvidas ou reagendamentos que se fizerem necessários poderão ser resolvidos pelo mesmo telefone ou pelo e-mail acima informados.

Agradecemos desde já e contamos com sua colaboração para dar prosseguimento a essa pesquisa.

Anna Lucia C. G. Taborda

Pesquisadora 
7.3 ANEXO C - Aprovação pelo Comitê de Ética

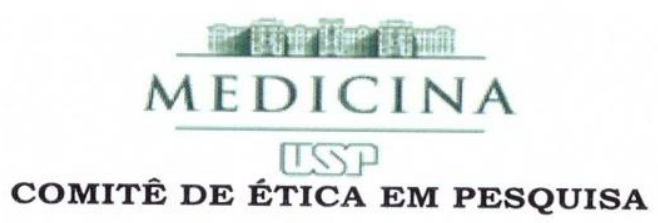

\section{APROVAÇÃo}

O Comitê de Ética em Pesquisa da Faculdade de Medicina da Universidade de São Paulo, em sessão de 30/03/2011, APROVOU o Protocolo de Pesquisa no 104/11 intitulado: "CARACTERIZAÇÃo DA RESISTENCIA PELA BUSCA DE ATENdimento pSicológico POR ESTUdANTES DE MEdicina” apresentado pelo Departamento de PATOLOGIA

Cabe ao pesquisador elaborar e apresentar ao CEPFMUSP, os relatórios parciais e final sobre a pesquisa (Resolução do Conselho Nacional de Saúde no 196, de 10/10/1996, inciso IX.2, letra "c").

Pesquisador (a) Responsável: Raymundo Soares de Azevedo Neto Pesquisador (a) Executante: Anna Lucia de Camargo Gargiulo Taborda

CEP-FMUSP, 30 de março de 2011.

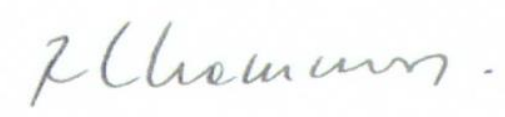

Prof. Dr. Roger Chammas Coordenador Comitê de Ética em Pesquisa 


\section{REFERÊNCIAS}




\section{REFERÊNCIAS}

Aberastury A, Knobel M. Adolescência normal:um enfoque psicanalítico. Porto Alegre, Artmed; 1981.

Alves, Hamer Nastasy P. et al. Perfil clínico e demográfico de médicos com dependência química. Rev. Assoc. Med. Bras.[online]. 2005, vol.51, n.3, pp. 139-143. ISSN 18069282. http://dx.doi.org/10.1590/S0104-42302005000300013.

Baldassin S. Níveis, fontes e estratégias de enfrentamento de estresse psicológico entre estudantes de medicina. 2003. 116p.

Baldassin S, Martins LC, Guerra A. Traços de ansiedade entre estudantes de Medicina. Arq Med ABC. 2006;27.

Baldassin S. Ansiedade e depressão no estudante de Medicina: revisão de estudos brasileiros. Cad ABEM. 2010;1(6):19-26.

Cunha JA. Manual da versão em português das Escalas de Beck. São Paulo: Casa do Psicólogo; 2001.

Chew-Graham CA, Rogers A, Yassin N. I wouldn't want it on my CV or their records': medical students' experiences of helpseeking for mental health problems. Med Educ. 2003;37(10):873-80

Czyz E, Horwitz AG, Eisenberg D, Kramer A, King CA. Self-reported barriers to professional help-seeking among college students at elevated risk for suicide. J Am Coll Health. 2013;61(7):398-406.

Downs MF, Eisenberg D. Help seeking and treatment use among suicidal college students. J Am Coll Health. 2012;60(2):104-14.

Dyrbye LN, Thomas MR, Shanafelt TD. Systematic review of depression, anxiety, and other indicators of psychological distress among U.S and Canadian medical students. Acad Med. 2006;81(4):354-73.

Eisenberg D, Golberstein E, Gollust S. Help-Seeking and Access to Mental Health Care in a University Population. Medical Care. 2007;45(7):594-601.

Eisenberg D, Hunt J, Speer N. Help Seeking for Mental Health on College Capuses: Review of Evidence and Next Steps for Research and Practice. Harvard Rev Psychiatry. 2012; 20(4):222-32.

Eisenberg, D., Hunt, J.B., Speer, N. Mental health in American Colleges and Universities: variation across student subgroups and across campuses. Journal of Nervous and Mental Disease . 2013;201(1):60-7. 
Freud A. O ego e seus mecanismos de defesa. Rio de Janeiro: Civilização Brasileira; 1996.

Freud S. (1895) Estudos sobre a histeria. In: Edição standard Brasileira das obras completas de Sigmund Freud. Rio de Janeiro: Imago; 1980. v. II.

Freud S. (1901) Sobre a psicopatologia da vida cotidiana. In: Edição standard Brasileira das obras completas de Sigmund Freud. Rio de Janeiro: Imago; 1980. v. VI.

Freud S. (1905) Fragmentos da análise de um caso de histeria. In: Edição standard Brasileira das obras completas de Sigmund Freud. Rio de Janeiro: Imago; 1980. v. VII.

Freud S. (1912) Uma nota sobre o inconsciente na psicanálise. In: Edição standard Brasileira das obras completas de Sigmund Freud. Rio de Janeiro: Imago; 1912. v. XII.

Freud S. (1914) Sobre o narcisismo: uma introdução. In: Edição standard Brasileira das obras completas de Sigmund Freud. Rio de Janeiro: Imago Editora; 1980. v. XIV, p. 89 - 107.

Freud S. (1917) Conferência XXVIII. In: Edição standard Brasileira das obras completas de Sigmund Freud. Rio de Janeiro: Imago Editora; 1980. v. XIV, v. XVII, p.534.

Freud S. (1926) Inibição, sintoma e ansiedade. In: Edição standard Brasileira das obras completas de Sigmund Freud. Rio de Janeiro: Imago Editora; 1980. v. XX, p. 181.

Freud S. (1937) Análise terminável e interminável. In: Edição standard Brasileira das obras completas de Sigmund Freud. Rio de Janeiro: Imago Editora; 1980. v. XXIII, p. 239.

Freud S. (1940) Esboço de psicanálise. In: Edição standard Brasileira das obras completas de Sigmund Freud. Rio de Janeiro: Imago Editora; 1980. v. XXIII, p. 169.

Grant A, Rix A, Winter P, Mattick K, Jones D. Support for medical students with mental health problems: a conceptual model. Acad Psychiatry. 2015;39(1):16-21.

Gorenstein C, Andrade L, Zuardi A. Inventário de Depressão de Beck: propriedades psicométricas da versão em português. In: Escalas de avaliação clínica e psiquiatria e farmacologia. São Paulo: Lemos Editora; 2000.

Guimarães K. Incidência de estresse e formação médica. Rev Psicol UNESP. 2006;5(1).

Hefner J, Eisenberg D. Social support and mental health in a university student population. Am J Orthopsychiatry. 1999;79(4): 491-499.

Hunt J, Eisenberg D. Mental health problems and help-seeking behavior among college students. J Adolesc Health. 2010;46(1):3-10.

Kessler, RC, Berglund P, Demler O, Jin R, Merikangas KR, Walters EE Life time prevalence and age of-onset distributons of DSM-IV disorders in the national comorbity survey replication. Arch. Gen Psychiatry. 2005;62(6):593-602. 
Klein M. Amor, culpa e reparação. In: Klein M. Amor culpa e reparação e outros trabalhos. Rio de Janeiro: Imago Editora; 1996. p.347-84.

Klein M. Uma contribuição à psicogênese dos estados maníaco-depressivos. In: Klein M. Amor culpa e reparação e outros trabalhos. Rio de Janeiro: Imago Editora; 1996, p.30129.

La Planche J, Pontalis JB. Vocabulário de psicanálise. São Paulo: Martins Fontes; 2000.

Levine RE, Breitkopf CR, Sierles FS, Camp G. Complications associated with surveying medical student depression. Acad Psychiatry. 2003;27(1):12-8.

Meleiro A. O médico como paciente. São Paulo: Ed. Lemos.1999.

Mello Filho J(org.). Identidade médica. São Paulo: Casa do Psicólogo Livraria e Editora Ltda. 2006.

Millan LR, Arruda PCV. Assistência psicológica ao estudante de Medicina: 21 anos de experiência. Rev Assoc Med Bras. 2008;54(1):90-4.

Millan LR. Vocação médica: um estudo do gênero. São Paulo: Casa do Psicólogo Livraria e Editora Ltda. 2005.

Millan LR, De Marco OLN, Rossi E, Arruda PCV. O universo psicológico do futuro médico: vocação, vicissitudes e perspectivas. São Paulo. Casa do Psicólogo Livraria e Editora Ltda. 1999.

Murray H. T.A.T. Teste de Apercepção Temática. São Paulo. Casa do Psicólogo Livraria e Editora Ltda. 1995.

National Survey of College Couseling Center, 2013. Disponível em: http://www.collegecounseling.org.

Nogueira-Martins L. Saúde mental do médico e do estudante de medicina. Psychiatry Online Brazil (1). Julho 1996. [Acesso em: 07 ago. 2009]. Disponível em: http://www.polbr.med.br/arquivo/saudmednt.htm.

Osório LC. Adolescente hoje. Porto Alegre, Artmed. 1992.

Roberts LW, Warner TD, Carter D, Frank E, Ganzini L, Lyketsos C. Caring for medical students as patients: access to service and care-seeking practices of 1,027 students at nine medical schools. J Ass Am Coll. 2000;75(3):272-7.

Silva MC. TAT aplicação e interpretação do Teste de Apercepção Temática. São Paulo: EPU. 1989.

Smith C, Peterson DF, Degenhardt BF, Johnson JC. Depression, anxiety, and perceived hassles among entering medical students. Psychol Health Med. 2007;12(1):31-9.

Storrie K, Ahern K, Tuckett A. A systematic review: Students with mental health problems - a growing problem. Int J Nurs Pract. 2010;16(1):1-6. 
Tjia J, Givens JL, Shea JA. Factors associated with undertreatment of medical student depression. J Am Coll Health. 2005;56(1):219-24.

Zivin K, Eisenberg D, Gollust S, Golberstein E. Persistence of mental health problems and needs in a college student population. $J$ Affect Disord. 2009;117(3):180-5.

Watkins D, Hunt J, Eisenberg D. Increased demand for mental health services on college campuses: perspectives from interviews of campus mental health administrators. Qualitative Social Work. 2012;11(3): 319-37.

Winnicott DW. Tudo começa em casa. São Paulo: Martins Fontes. 1989.

World Federation For Mental Health, 2012. Depression: A Global Crisis. Disponível em http://www.who.int/mental_health/management/depression/wfmh_paper_depression_w mhd_2012.pdf. 